Ciência e Tecnologia

dos Alimentos
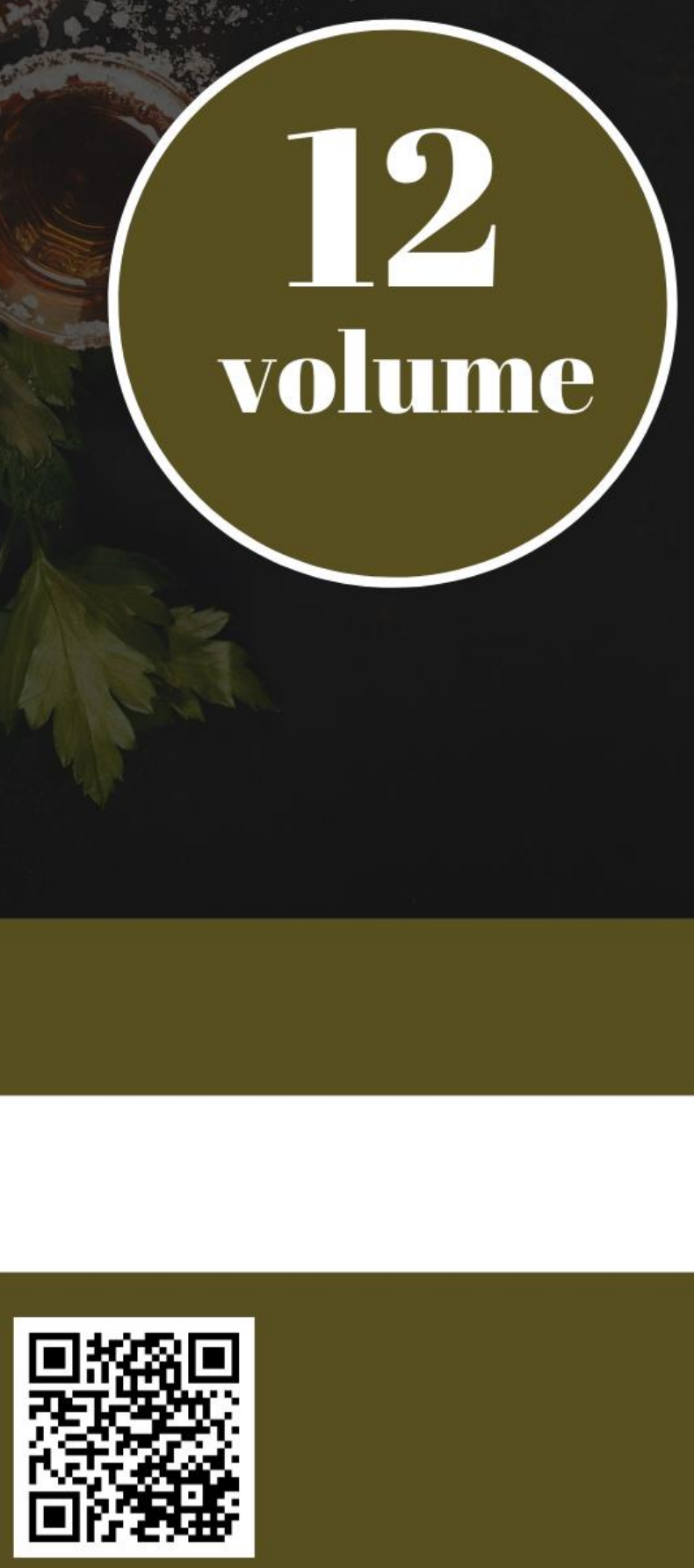

Editora Poisson 
Editora Poisson

\section{Ciência e Tecnologia dos Alimentos Volume 12}

1a Edição

Belo Horizonte

Poisson

2021 
Editor Chefe: Dr. Darly Fernando Andrade

\section{Conselho Editorial}

Dr. Antônio Artur de Souza - Universidade Federal de Minas Gerais

Msc. Davilson Eduardo Andrade

Dra. Elizângela de Jesus Oliveira - Universidade Federal do Amazonas

Msc. Fabiane dos Santos

Dr. José Eduardo Ferreira Lopes - Universidade Federal de Uberlândia

Dr. Otaviano Francisco Neves - Pontifícia Universidade Católica de Minas Gerais

Dr. Luiz Cláudio de Lima - Universidade FUMEC

Dr. Nelson Ferreira Filho - Faculdades Kennedy

Msc. Valdiney Alves de Oliveira - Universidade Federal de Uberlândia

\begin{tabular}{|l} 
Dados Internacionais de Catalogação na Publicação (CIP) \\
Ciência e Tecnologia dos Alimentos-Volume 12/ Organização Editora \\
Poisson - Belo Horizonte - MG: Poisson - 2021 \\
Formato: PDF \\
ISBN: 978-65-5866-118-4 \\
DOI: 10.36229/978-65-5866-118-4 \\
Modo de acesso: World Wide Web \\
Inclui bibliografia \\
1. Tecnologia de Alimentos 2. Alimentos 3. Nutrição I. Título \\
\end{tabular}

O conteúdo dos artigos e seus dados em sua forma, correção e confiabilidade são de responsabilidade exclusiva dos seus respectivos autores 


\section{SUMÁRIO}

Capítulo 1: Análise da qualidade microbiológica de cremes de açaí (Euterpe oleracea, Mart.) congelados comercializadas em açaiterias e supermercados de Governador Valadares/MG 06

Juliana Lopes Silva, Matheus Bellice Gregório, Nelson Gomes de Oliveira Júnior, Yasmin Kellen de Oliveira Machado, Eloísa Helena Medeiros Cunha, Anderson Ferreira Vilela, Ana Clara de Alvarenga Morais, Thais Silveira Pereira

DOI: $10.36229 / 978-65-5866-118-4 . C A P .01$

Capítulo 2: Características microbiológicas do queijo coalho com e sem registro, comercializado nos períodos seco e chuvoso na cidade de Serra Talhada-PE

Mailza Gonçalves de Souza, Fabiana Maria da Silva, Virgínia Medeiros de Siqueira, Fernando Felipe da Silva Pereira, Abigail Jaynnara Gomes da Silva Almeida, Keyla Laura de Lira dos Santos, Rafael Lopes Soares

DOI: $10.36229 / 978-65-5866-118-4 . C A P .02$

Capítulo 3: Análise da presença de amido em queijos do tipo manteiga comercializados em Sousa-PB

Grazielly Mirelly Sarmento Alves da Nóbrega, Naiara Menezes Bezerra, Mateus Gonçalves Silva, José Ramon Afonso da Silva, Amanda Raquel Guerreiro Maia, Suely Cristina Pereira de Lima Oliveira

DOI: $10.36229 / 978-65-5866-118-4 . C A P .03$

Capítulo 4: Determinação de compostos bioativos em iogurte de leite de cabra adicionado de polpa de cupuaçu

Daniela Cavalcante dos Santos Campos, Beatriz Oliveira de Souza, Viviane Antunes Pimentel, Rogério Lopes Xavier, Adriana Flach, Luiz Antônio Mendonça Alves da Costa, Anderson do Nascimento Silva, Lailson Oliveira de Sousa

DOI: $10.36229 / 978-65-5866-118-4 . C A P .04$

Capítulo 5: Processamento térmico do leite: Termização, pasteurização e UHT. 28

Cintia da Silva Araújo, Wallaf Costa Vimercati, Leandro Levate Macedo, Raquel Reis Lima, Cíntia Tomaz Sant'Ana, Solciaray Cardoso Soares Estefan de Paula, Magno Fonseca Santos, Hygor Lendell Silva de Souza, Pedro Henrique Alves Martins, Hugo Calixto Fonseca, Ramon Ramos de Paula

DOI: $10.36229 / 978-65-5866-118-4 . C A P .05$

Capítulo 6: Análise de vitaminas hidrossolúveis em suplementos 34

Lucile Tiemi Abe-Matsumoto, Geni Rodrigues Sampaio, Deborah Helena Markowicz Bastos

DOI: $10.36229 / 978-65-5866-118-4 . C A P .06$ 


\section{SUMÁRIO}

Capítulo 7: Elaboração de bolinhos fritos com farinha de arroz (Oryza sativa L.) ...... 40

Arianne Dantas Viana, Gleyce Swellen de Azevedo Moura, Maria José de Figueiredo, Mikassia Rosa Faustino, Karolayne da Silva Luz, Felipe Moreira da Silva, Anderson Ferreira Vilela, Erick Gabriel da Silva DOI: $10.36229 / 978-65-5866-118-4 . C A P .07$

Capítulo 8: Atividade antioxidante de hidrolisados proteicos de feijão preto (Phaseolus vulgaris $L$.) 44

Jarine Amaral do Evangelho, José de Jesus Berrios, Mariana Dias Antunes Porto, Nathan Levien Vanier, Vânia Zanella Pinto, Elessandra da Rosa Zavareze

DOI: 10.36229/978-65-5866-118-4.CAP.08

Capítulo 9: Modelagem da solubilidade do $\beta$-sitosterol em solventes orgânicos usando o modelo NRTL 48

Vanessa Vilela Lemos, Karolina Soares Costa, Jéssica Cristina Silva Resende, Marlus Pinheiro Rolemberg, Rodrigo Corrêa Basso

DOI: 10.36229/978-65-5866-118-4.CAP.09

Autores: 


\section{Capítulo 1}

Análise da qualidade microbiológica de cremes de açaí (Euterpe oleracea, Mart.) congelados comercializadas em açaiterias e supermercados de Governador Valadares/MG

Juliana Lopes Silva

Matheus Bellice Gregório

Nelson Gomes de Oliveira Júnior

Yasmin Kellen de Oliveira Machado

Eloísa Helena Medeiros Cunha

Anderson Ferreira Vilela

Ana Clara de Alvarenga Morais

Thais Silveira Pereira

Resumo: 0 açaí é uma fruta tipicamente encontrada na floresta amazônica que tem ganhado visibilidade recentemente. Os derivados dessa fruta, como a polpa e o creme, têm se mostrado mais comum na alimentação cotidiana do brasileiro, sendo um alimento com alto teor energético, rico em diversas vitaminas, minerais, ômega 6 e 9. Por conta dessa popularidade e versatilidade, o açaí encontra-se em crescimento exponencial, sendo o produto exportado para diversos países. É de suma importância garantir que o alimento esteja seguro para seu consumo. Portanto o objetivo do nosso trabalho foi analisar e avaliar a qualidade microbiológica das amostras de cremes de açaí congeladas de diversas marcas comercializadas na cidade de Governador Valadares (MG) de acordo com os parâmetros propostos pela legislação, procurando identificar e quantificar a presença de Escherichia coli e Salmonella spp.. Foram analisadas 10 marcas de creme de açaí, no período de setembro de 2020, sendo 5 adquiridas em 3 grandes supermercados e os demais em 5 açaiterias no centro da cidade devido ao seu fácil acesso. Os dados demonstraram que apenas as amostras H e I apresentaram resultados positivos para Escherichia coli e em relação à Salmonella spp., todas as amostras apresentaram ausência em 25 g. Os resultados encontrados nas análises microbiológicas das dez marcas de creme de açaí, demonstraram que todas as amostras analisadas estão em adequação aos parâmetros microbiológicos estabelecidos pela legislação. É importante que cuidados especiais nas Boas Práticas de Manipulação sejam tomados durante todo processamento do creme e que haja maior controle por parte das instituições de fiscalização sanitária para a obtenção de uma melhor qualidade da creme de açaí comercializada para os consumidores.

Palavras chave: Análise microbiológica, Creme de açaí, Escherichia coli, Salmonella spp., coliformes totais. 


\section{INTRODUÇÃO}

O açaí é uma fruta do açaizeiro (Euterpe oleracea, Mart.) de cor roxa típica da região amazônica. Rico em fibras, ômegas 6 e 9, flavonoides (antocianinas), minerais (Mn, Fe, $\mathrm{Zn}, \mathrm{Cu}, \mathrm{Cr}$ ), vitaminas B1 e E (ALMICO et al., 2018).

Por ser um alimento saudável, o açaí está sendo cada vez mais buscado entre os consumidores que se interessam por maior qualidade de vida. Além dos nutrientes citados anteriormente, o açaí proporciona ações anti-inflamatórias, combate à dislipidemia, ao diabetes mellitus do tipo 2, ao envelhecimento e ao câncer (CARVALHO et al., 2018). 0 açaí é considerado um alimento funcional, que de acordo com Cedrim et al. (2018), se caracteriza por auxiliar positivamente em uma ou mais funções fisiológicas dos organismos. Da fruta é produzida xarope, geléia, pó, sorvete, creme e principalmente a polpa (ALMICO et al., 2018).

Ultimamente a comercialização do açaí fruto está bastante difundida no cenário nacional e internacional, devido principalmente, às suas propriedades nutricionais e por ser um alimento com inúmeras funções na dieta humana (DA SILVA et al., 2020). Rocha (2015), afirma que o açaí está se tornando um produto de grande visibilidade no setor nutricional por ser fonte de diversos nutrientes, sendo recomendável na dieta da população (COSTA et al., 2016). Embora já consumido historicamente na região amazônica, tornou-se popular apenas a partir da década de 1990, passando a ser comercializado para demais regiões do Brasil e exportado para países como China, Japão, Estados Unidos e parte da Europa (MOURÃO, 2010). Em 2019, foi observada uma produção de 222.706 toneladas de açaí com a exportação média de 42 mil toneladas para outras regiões do mundo, sendo que 82\% dessa exportação apenas para os EUA (BRASIL, 2019).

A legislação que regulamenta a qualidade de polpa de frutas no Brasil é a Instrução Normativa (IN) nº 1, de 7 de janeiro de 2000, do Ministério da Agricultura, Pecuária e Abastecimento (MAPA), que define os Padrões de Identidade e Qualidade (PIQ's) e pela Resolução de Diretoria Colegiada (RDC) no 331, de 23 de dezembro de 2019 da Agência Nacional de Vigilância Sanitária (ANVISA), que regulamenta os Padrões Microbiológicos para Alimentos, revogando a resolução anterior, RDC no 12 de 02 de janeiro de 2001, e passando a vigorar a partir de 23 de dezembro de 2020.

De acordo com Marinho et al. (2018), a fruta do açaí possui uma elevada carga microbiana, que associado a atividade enzimática do vegetal e a valores do $\mathrm{pH}$ em torno de 5,0, apresenta uma elevada perecibilidade, um máximo de 12 horas de vida útil se conservado sob refrigeração. Os principais problemas de origem higiênico sanitária que o consumo do fruto contaminado pode ocasionar são os surtos alimentares. A qualidade das polpas de frutas está relacionada com a condição da matéria-prima, de transporte e processamento e o tipo de embalagem (SOUZA et al. 2020). Sem esses cuidados, a possibilidade do açaí em se tornar um veículo de agentes causadores de doenças transmitidas por alimentos (DTA) será potencializada (ALMICO et al., 2018). Sendo assim, é de suma importância, a análise microbiológica para monitorar as condições higiênico-sanitárias da polpa do açaí (ALMICO et al., 2018).

Diante disso, o objetivo deste trabalho foi, por meio de uma amostragem indicativa, analisar e avaliar a qualidade microbiológica dos cremes de açaí congelados de diversas marcas comercializadas na cidade de Governador Valadares (MG), de acordo com os parâmetros propostos pela legislação, procurando identificar e quantificar a presença de Escherichia coli e Salmonella spp..

\section{MATERIAIS E MÉTODOS}

A pesquisa realizada consiste em um estudo quantitativo explicativo, em que foram analisadas 10 marcas de creme de açaí, sendo 5 adquiridas em 3 grandes supermercados no município de Governador Valadares (MG) e os demais em 5 açaiterias populares no centro da cidade devido ao seu fácil acesso, seguindo as recomendações da RDC no 331/2019 para leitura e expressão dos resultados do experimento. As amostras foram adquiridas e imediatamente acondicionadas em caixas isotérmicas com gelo a fim de preservar sua temperatura. Foram encaminhados ao Laboratório de Microbiologia da Universidade Vale do Rio Doce (UNIVALE), para realização das análises: coliformes totais, termotolerantes e Salmonella spp. No laboratório foi realizada a desinfecção externa das embalagens de açaí com álcool $70 \%$ e as amostras foram codificadas em: A, B, C, D, E, F, G, H, I e J.

Foi feita uma análise estatística descritiva em que as unidades dos resultados foram expressas em Número Mais Provável por grama de amostra (NMP/g) para coliformes totais e Escherichia coli. empregando a tabela de Hoskins (SILVA et al., 2017). Para Salmonella spp. os resultados são expressos como presença ou ausência de Salmonella em 25 g de amostra. 
Os resultados das análises para Escherichia coli. e Salmonella spp., foram baseadas na Resolução da ANVISA RDC no 331 de 23 de dezembro de 2019 e sua Instrução Normativa n 60 de 23 de dezembro de 2019, na classificação de polpas e purês, subgrupo de frutas e derivados (BRASIL, 2019).

\subsection{COLIFORMES TOTAIS E COLIFORMES TERMOTOLERANTES}

Foram retirados $25 \mathrm{~g}$ de amostra e transferido para um frasco contendo $225 \mathrm{~mL}$ de água peptonada (diluição $10-^{1}$ ). A partir dessa diluição procedeu-se com as diluições sucessivas $10-^{2}, 10-^{3}, 10-{ }^{4}$. Alíquotas de $1 \mathrm{~mL}$ de cada diluição foram inoculadas em três tubos com $9 \mathrm{~mL}$ de caldo Lauril Sulfato Triptose (LST) contendo tubo de Durham invertido e incubados por 48hs a uma temperatura de 37 ㅇ (FARIA et al., 2013). Passado o tempo de incubação, foi observada a produção de gás nos tubos E, F, H e I. Destes tubos com presença de gás, foram pegas três alças de $10 \mathrm{uL}$ de cada cultura aos tubos de caldo Bile Verde Brilhante (VB) contendo tubo de Durham invertido para a confirmação de coliformes totais. Novamente incubados por 48hs a uma temperatura de $37^{\circ} \mathrm{C}$, observou-se a produção de gás em todos eles. Para a confirmação de coliformes termotolerantes, foi tomado $10 \mathrm{uL}$ dos tubos E, F, H e I aos tubos com $5 \mathrm{~mL}$ de caldo E. coli contendo tubo de Durham invertido. Os tubos foram incubados a uma temperatura de $45,5^{\circ} \mathrm{C}$ por 48 hs. Passado o tempo, foi observada produção de gás nos tubos H e I.

\subsection{SALMONELLA SPP}

Para análise de Salmonella spp., foram retirados $25 \mathrm{~g}$ de amostra e transferida para $225 \mathrm{~mL}$ de caldo lactosado, sucedido de incubação a $37{ }^{\circ} \mathrm{C}$, por $24 \mathrm{hs}$. Passado o tempo de incubação, seguiu-se com o enriquecimento seletivo com 0,1 mL em $10 \mathrm{~mL}$ de caldo Rappaport-Vassiliadis (RV) e $1 \mathrm{~mL}$ em $10 \mathrm{~mL}$ de caldo tetrationato (TT), e incubados a $43{ }^{\circ} \mathrm{C}$ por $24 \mathrm{hs}$ e $35^{\circ} \mathrm{C}$ em $24 \mathrm{hs}$, respectivamente (ALMICO et al., 2018). Após a incubação, foi estriado inóculos dos dois caldos de enriquecimento em placas de ágar Hektoen (HE) e ágar Xilose Desoxicolato (XLD), sendo novamente incubadas a $37^{\circ} \mathrm{C}$ por mais $24 \mathrm{hs}$ (BRASIL, 2011). Não houve formação de colônias de Salmonellas spp.

\section{RESULTADOS}

Na tabela 1 estão expressos os resultados da avaliação microbiológica para coliformes totais, Escherichia coli e Salmonella spp., dos cremes de açaí analisadas como também a referência padronizada pela Resolução no 331/2019 no que se refere aos padrões microbiológicos para coliformes totais, Escherichia coli e Salmonella spp.

Os dados na tabela 1 demonstram que apenas as amostras $\mathrm{H}$ e I apresentaram resultados positivos para Escherichia coli, porém estavam dentro dos padrões da legislação. Todas as amostras apresentaram ausência de Salmonella spp. em 25 g de amostra.

Em números totais das análises realizadas $40 \%(n=4)$ das amostras estavam contaminadas com coliformes totais e $20 \%(\mathrm{n}=2)$ com Escherichia coli.

0 gráfico 1 apresenta os resultados em percentuais totais comparando os diferentes comércios, onde foram coletadas as amostras analisadas. Nas amostras coletadas em açaiterias, $60 \%(n=3)$ apresentaram coliformes totais, enquanto $20 \%(\mathrm{n}=1)$ eram das amostras de supermercados. Quanto à presença de Escherichia coli, $40 \%(\mathrm{n}=2)$ das amostras de açaiterias apresentaram resultados positivos para esta bactéria, enquanto nenhuma das amostras dos supermercados apresentou Escherichia coli. Não houve presença de Salmonella spp. nas amostras colhidas das açaiterias e supermercados 
Tabela 1- Distribuição do Número Mais Provável de Coliformes Totais, Escherichia Coli e pesquisa de Salmonella spp. nas amostras de cremes de açaí congeladas analisadas.

\begin{tabular}{|c|c|c|c|}
\hline \multirow{2}{*}{ Amostra } & Coliformes totais (NMP/g) & Escherichia coli (NMP/g) & Salmonella spp. \\
\hline A & - & - & Ausente \\
\hline B & - & - & Ausente \\
\hline C & - & - & Ausente \\
\hline D & $0,4 \times 10^{1}$ & - & Ausente \\
\hline E & $9,3 \times 10^{1}$ & Ausente \\
\hline F & - & - & Ausente \\
\hline G & $4,3 \times 10^{1}$ & $2,3 \times 10^{1}$ & Ausente \\
\hline H & $0,9 \times 10^{1}$ & $0,9 \times 10^{1}$ & Ausente \\
\hline I & - & - & Ausente \\
\hline J & - & $10^{2}$ & Ausente \\
\hline *Padrão & \multicolumn{2}{|c|}{${ }^{*}$} & Ausente em 25g \\
\hline
\end{tabular}

*Resolução n 331/2019 da Anvisa

Gráfico 1 - Resultados percentuais da presença de coliformes totais, Escherichia coli e Salmonella spp. Encontrados em açaiterias e supermercados.

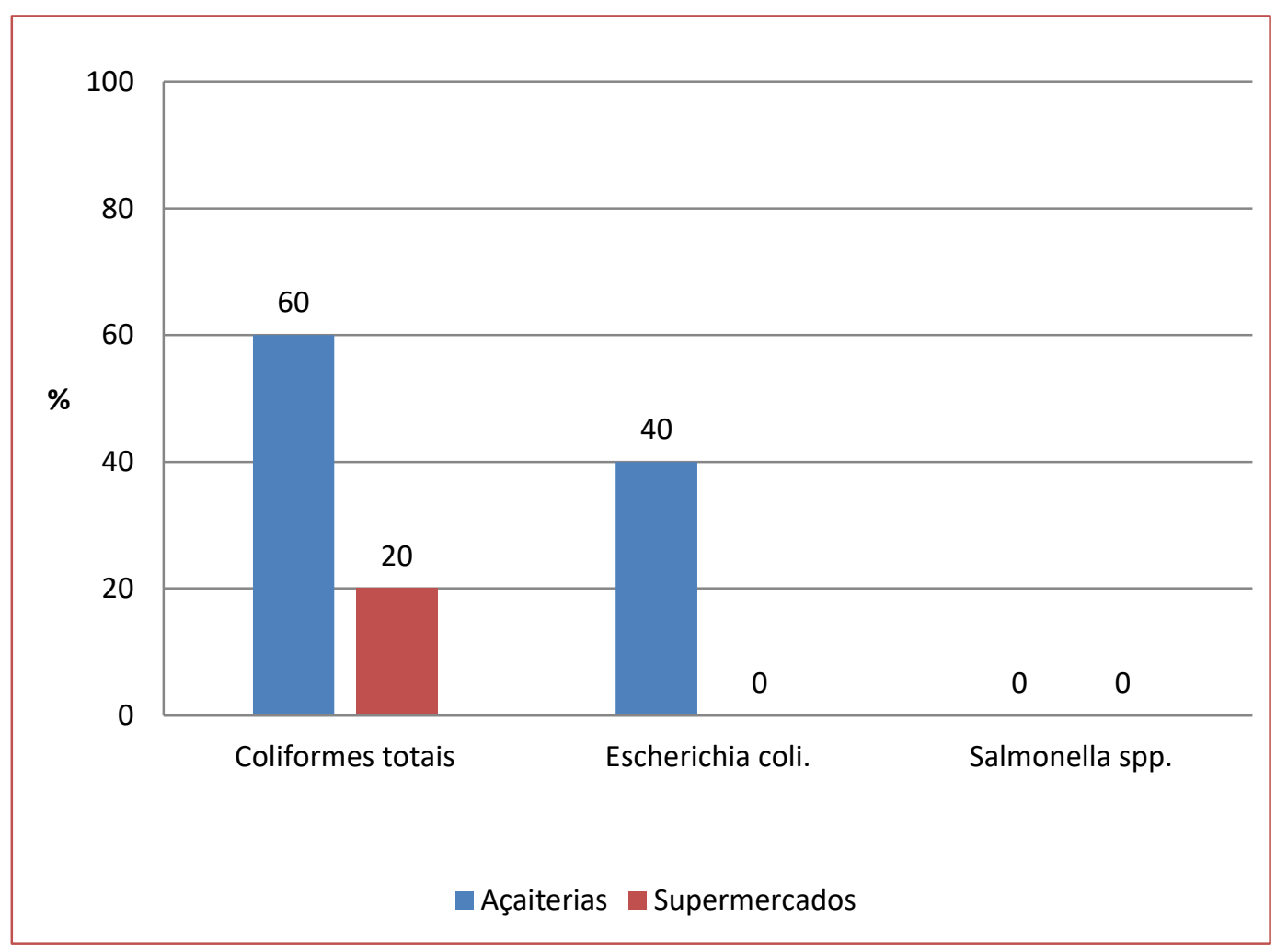




\section{DISCUSSÃO}

A resolução n 331 (BRASIL, 2019), regulamenta como padrão microbiológico a contagem de Escherichia coli até $10^{2} \mathrm{NMP} / \mathrm{g}$, dessa forma, como apresentado pela Tabela 1, as amostras de creme de açaí avaliadas estão de acordo com o que é preconizado pela legislação brasileira. A presença de bactérias do grupo coliformes termotolerantes, especialmente Escherichia coli, indica provável contaminação dos alimentos com material de origem fecal. Essa contaminação pode estar integrada à qualidade da água utilizada no processo, ou com práticas inadequadas de higiene pessoal dos manipuladores (FARIA et al., 2013).

Foi observada através da Tabela 1 a ausência do crescimento de Salmonella spp. em $25 \mathrm{~g}$ das amostras de creme de açaí. Uma das justificativas para sua ausência nas amostras analisadas é que a microbiota natural desta bactéria remete principalmente à alimentos de origem animal. Segundo Franciele et al. (2019), os veículos mais frequentes de transmissão da Salmonella spp. são os alimentos de origem animal, principalmente os produtos avícolas (STOCCO, 2017). Por ser uma bactéria patogênica, a RDC n 331/2019 (BRASIL, 2019), determina a ausência em 25 gramas de amostra para este microrganismo. Sendo assim, todas as 10 amostras analisadas estão dentro dos padrões de qualidade exigidos pela legislação.

Estudo de Araújo et al. (2019) em estabelecimentos de Recife/PE, os resultados confirmaram a necessidade de boas práticas para manipulação e cuidado no transporte das polpas de açaí. Das 5 amostras analisadas, $100 \%$ apresentaram resultado positivo para coliformes totais. Dos quais $80 \%$ foi considerada aceitável e $20 \%$ apresentou níveis de coliformes acima do permitido pela legislação. A conclusão quanto a contagem de Salmonella spp., foi negativa, não houve presença.

De acordo com as análises obtidas por Das Chagas Costa et al. (2020), em feiras livres na cidade de Manaus/AM, cinco amostras de polpa de açaí apresentaram a presença de coliformes totais e quatro amostras foram positivas para coliformes fecais, chegando à conclusão que diante dos resultados, suas amostras são impróprias para o consumo podendo ocasionar risco à saúde do consumidor.

Da mesma forma, Souza et al. (2019), ao analisar a presença desses microrganismos em feiras livres de Porto Velho/RO, os resultados obtidos demonstraram que 3 amostras de polpa de açaí apresentaram contaminação por coliformes totais e termotolerantes, e nenhuma obteve a presença de Salmonella spp. Com isso, concluíram que as condições higiênico-sanitárias associadas ao açaí são falhas, sendo necessário mais estudo para averiguar a qualidade microbiológica do açaí ofertado à população.

Para Marinho et al. (2018), os resultados obtidos nos mercados públicos de São Luís/MA mostraram que os parâmetros se encontraram fora dos padrões previstos em lei. As amostras de polpa de açaí apresentaram contaminação por coliformes totais e Escherichia coli, entretanto não houve resultado positivo na pesquisa para Salmonella spp. Nesse contexto, chegou-se à conclusão de que a situação requer elaboração e implementação de ações de fortalecimento de vigilância sanitária nesses locais.

Vários estudos mostram a importância das boas práticas de fabricação estabelecidas pela RDC n 216 de 15 de setembro de 2004 (BRASIL, 2004) para a obtenção de um produto com adequadas condições higiênicosanitárias. Grande parte das doenças transmitidas por alimentos advém de uma manipulação incorreta (NETO et al. 2018). É importante que a limpeza dos utensílios e do ambiente, onde é realizado o processamento do fruto, esteja nas condições indicadas pelas boas práticas, não devendo ser negligenciado o bom asseio dos manipuladores (NETO et al. 2018). Nos estabelecimentos que comercializam o açaí na tigela, o local em que há manipulação da polpa para a adição dos demais ingredientes, também é necessário seguir as normas sanitárias estabelecidas, por ser um ambiente onde pode ocorrer contaminação do produto e trazer danos à saúde dos consumidores podendo até resultar na morte (NETO et al. 2018).

Neste contexto, a presença de um nutricionista capacitado na unidade é importante para o cumprimento das ações de garantia da segurança alimentar, pois, a atuação deste profissional como agente de saúde, fará cumprir o que as Leis e Resoluções determinam para uma produção segura de alimentos (JÚNIOR et al., 2020). 


\section{CONCLUSÃO}

Os resultados encontrados nas análises microbiológicas das dez amostras de creme de açaí, demonstraram que todas as amostras analisadas apresentaram 100\% de adequação em relação aos parâmetros microbiológicos estabelecidos pela legislação. É de extrema importância que cuidados especiais nas Boas Práticas de Manipulação sejam tomados durante todo processamento do creme e que haja maior controle por parte das instituições de fiscalização sanitária para a obtenção de uma melhor qualidade do creme de açaí comercializado para os consumidores.

\section{REFERÊNCIAS}

[1] ALMICO, J. D.; FERREIRA, I. M.; RAMOS, G. D.; E SILVA, A. M. O.; DE CARVALHO, M. G. Avaliação da qualidade microbiológica, físico-química e química de polpas de açaí (Euterpe oleracea Mart) pasteurizadas congeladas comercializadas em Aracaju-SE. Revista Brasileira de Higiene e Sanidade Animal, v. 12, n. 2, p. 156-168, 2018.

[2] ARAÚJO, B. A. R.; SABINO, M. M.. Análise de rótulo e microbiológica de polpas de açaí comercializadas em estabelecimentos do Recife e Região Metropolitana do Recife-PE. 2019.

[3] BRASIL. Agência Nacional de Vigilância Sanitária. Resolução RDC, n. 12 de 02 de janeiro de 2001. Aprova o regulamento técnico sobre padrões microbiológicos para alimentos. Diário Oficial da União, 2001.

[4] BRASIL. Agência Nacional de Vigilância Sanitária. Resolução RDC, n. 216 de 15 de setembro de 2004. Aprova o Regulamento Técnico de Boas Práticas para Serviços de Alimentação. Diário Oficial da União, 2004.

[5] BRASIL. Agência Nacional de Vigilância Sanitária. Resolução RDC, n. 331 de 23 de dezembro de 2019. Aprova o regulamento técnico sobre padrões microbiológicos para alimentos. Diário Oficial da União, 2019.

[6] BRASIL, Instituto Brasileiro de Geografia e Estatística. Produção da Extração Vegetal e da Silvicultura. [S. l.], 2019. Disponível em: https://sidra.ibge.gov.br/pesquisa/pevs/quadros/brasil/2018. Acesso em: 26 jun. 2020.

[7] BRASIL. Instrução Normativa $\mathrm{n}^{\circ}$ 1, de 7 de janeiro de 2000. Regulamento técnico geral para fixação dos padrões de identidade e qualidade para polpa de fruta. Diário Oficial [da] República Federativa do Brasil, 2000.

[8] BRASIL. Instrução Normativa no 60, de 23 de janeiro de 2019. Estabelece as listas de padrões microbiológicos para alimentos. Diário Oficial União, 2019.

[9] BRASIL, Ministério da Saúde; Secretaria de Vigilância em Saúde. Manual técnico de diagnóstico laboratorial de Salmonella spp.: diagnóstico laboratorial do gênero Salmonella. Fundação Oswaldo Cruz. Laboratório de Referência Nacional de Enteroinfecções Bacterianas, Instituto Adolfo Lutz. - Brasília, 2011.

[10] CARVAlHO, G. L. B.; GAldino, R. S.; CAVAlCANTE, W. M. A.; DE AQUinO, D. S. A. Doença de Chagas: Sua transmissão através do consumo de açaí. Acta de Ciências e Saúde, v. 1, n. 1, p. 1-13, 2018.

[11] CEDRIM, P. C. A. S.; BARROS, E. M. A.; NASCIMENTO, T. G. do. Propriedades antioxidantes do açaí (Euterpe oleracea) na síndrome metabólica. Brazilian Journal of Food Technology, v. 21, 2018.

[12] COSTA, N. M. B.; ROSA, C. de O. B. Alimentos funcionais: componentes bioativos e efeitos fisiológicos. Editora Rubio, 2016.

[13] DA SILVA, A. O.; MERA, W. Y. W. L.; SANTOS, D. C. R.; DE SOUZA, D. P.; SILVA, C. G. N.; RAIOL, L. L.; JÚNIOR, A. M. G. S.; SILVA, D. A. S.; VIÉGAS, I. J. M. Estudo da produção de açaí (Euterpe oleracea Mart): aspectos econômicos e produtivos baseados nos anos de 2015 a 2017. Brazilian Journal of Development, v. 6, n. 1, p. 1629-1641, 2020.

[14] DAS CHAGAS COSTA, S. C. F.; GOMES, M. C. F.; ERAZO, R. L.; CARVALHO, E. B. S.; ALENCAR, Y. B.. Análise da qualidade microbiológica de polpas de açaí comercializadas em cinco feiras livres da cidade de Manaus. Brazilian Journal of Development, v. 6, n. 7, p. 47667-47677, 2020.

[15] FARIA, M.; OLIVEIRA, L. B. D.; COSTA, F. D. C. DETERMINAÇÃO DA QUALIDADE MICROBIOLÓGICA DE POLPAS DE AÇAÍ CONGELADAS COMERCIALIZADAS NA CIDADE DE POUSO ALEGRE-MG. Alimentos e Nutrição Araraquara, v. 23, n. 2, p. 243-249, 2013.

[16] FRANCIELE, C.; PAGANO, M.. Prevalência de infecções causadas por Salmonella sp. no Brasil no período de 2013 a 2017. Journal of Infection Control, v. 8, n. 2, 2019.

[17] JÚNIOR, G. N. S.; ANDRADE, C. A.; MILANESI, G. A.; MILANESI, F. A; MILANESI, A.; SILVA, L. S. G. R.; BEZERRA, R. A.. A relevância do responsável técnico nutricionista na prevenção de surtos alimentares em unidades de alimentação e nutrição. Brazilian Journal of Development, v. 6, n. 10, p. 77795-77807, 2020.

[18] MARINHO, S. C.; MOUTA, A. R. N.; RABÊLO, H. P. S. M.; DA SILVA, G. M.; FURTADO, J. G. C. CONDIÇÕES MICROBIOLÓGICAS DE POLPAS CONGELADAS DE AÇAÍ COMERCIALIZADAS EM MERCADOS PÚBLICOS DE SÃO LUÍSMA. Journal of Health Connections, v. 2, n. 1, 2018.

[19] MOURÃO, L. História e natureza: do açaí ao palmito. Territórios e Fronteiras, v. 3, n. 2, p. 74-96, 2010. 
[20] NETO, A. F.; VASCONCELOS, C. E.; FIGUEIREDO, E. L.. Avaliação higiênico-sanitária e microbiológica de estabelecimentos que comercializam açaí (Euterpe oleracea Mart.) em Igarapé-Miri - Pará. Brazilian Journal of Food Research. Campo Mourão, ano 2018, v. 9, n. 2, p. 15-29, 12 jun. 2018.

[21] ROCHA, S. M. B. M. Benefícios funcionais do açaí na prevenção de doenças cardiovasculares. Journal of Amazon Health Science, v. 1, n. 1, p. 1-10, 2015.

[22] SILVA, N.; JUNQUEIRA, V.C.A.; SILVEIRA, N. F. A.; TANIWAKI, M. H. Manual de métodos de análise microbiológica de alimentos e água. 5. ed. São Paulo: Blucher, 2017.

[23] SOUZA, A. B.; GOMES, M. A. S.. Análise microbiológica da polpa de açaí comercializada em feiras livres na cidade de Porto Velho/RO. 2019.

[24] SOUZA, A. C. F.; SOUZA, J. F.; MENDES, I. G.. Avaliação microbiológica de polpas congeladas de frutas comercializadas em feiras públicas da cidade de Macapá, Amapá. Research, Society and Development, v. 9, n. 2, p. e191922152-e191922152, 2020.

[25] STOCCO, C. W. Controle de qualidade microbiológico em frigorífico. 85f. 2017. Dissertação (Mestrado em Engenharia de Produção), Programa de Pós-Graduação em Engenharia de Produção da Universidade Tecnológica Federal do Paraná, Ponta Grossa, 2017. 


\section{Capítulo 2}

Características microbiológicas do queijo coalho com e sem registro, comercializado nos períodos seco $e$ chuvoso na cidade de Serra Talhada-PE

Mailza Gonçalves de Souza

Fabiana Maria da Silva

Virgínia Medeiros de Siqueira

Fernando Felipe da Silva Pereira

Abigail Jaynnara Gomes da Silva Almeida

Keyla Laura de Lira dos Santos

Rafael Lopes Soares

Resumo: Especialmente fabricado e comercializado no nordeste brasileiro, o queijo coalho pode ser adquirido em diversos formatos, tamanhos e pesos, e sob diferentes métodos de conservação, apesar de haver uma legislação bem clara sobre esse parâmetro. Por ser um alimento altamente perecível, objetivou-se avaliar as características microbiológicas (coliformes termotolerantes, Staphylococcus aureus e Salmonella) desse produto, comercializado em diferentes períodos. Foram analisadas 20 amostras (10 com registro e 10 sem registro) coletadas nos meses de junho de 2018 (período seco; $\mathrm{n}=10$ ) e janeiro de 2019 (período chuvoso; $n=10$ ), sendo que em cada período foram coletados nos mesmos locais de comercialização e sendo os mesmos fabricantes. Nas analises para coliformes termotolerantes, $70 \%$ das amostras apresentaram valores superiores ao permitido pela legislação no período seco, e 100\% das amostras estavam com valores superiores no período chuvoso. Para Salmonella, 10\% tiveram resultado positivo no período seco, e $50 \%$ foram positivas no período chuvoso, sendo que este microrganismo deve estar ausente nesse tipo de produto. 0 resultado para analise de Staphylococcus aureus foi negativo para $100 \%$ das amostras nos dois períodos analisados. 0 queijo coalho comercializado não atende aos requisitos estabelecidos pela legislação, apresentando riscos à saúde da população.

Palavras Chave: Contaminação, Derivado lácteo, Saúde pública. 


\section{INTRODUÇÃO}

O queijo coalho é um produto tipicamente nordestino, se destacando nos estados do Ceará, Rio Grande do Norte, Paraíba e Pernambuco. Sendo amplamente comercializado, esse tipo de queijo apresenta grande aceitação pelos consumidores, sendo consumido das mais diversas formas, como, natural, assado, frito ou na criação de pratos na culinária (Nassu et al., 2006).

O queijo coalho é um produto obtido a partir da coagulação do leite, essa coagulação ocorre por meio da ação do coalho ou de outras enzimas coagulantes. (Brasil, 2001). Apresentando consistência semidura elástica, de cor branca amarelada uniforme, de odor ligeiramente ácido, a textura pode conter algumas olhaduras pequenas ou sem olhaduras, de forma, tamanho e peso variáveis (Brasil, 2006).

0 primeiro passo na garantia da qualidade microbiológica do queijo é a comprovação da qualidade do leite, a microbiota presente na matéria prima exerce influência direta no produto final. A alta carga microbiana acelera a multiplicação de microrganismos patogênicos e, dessa forma, diminui o tempo de conservação dos queijos (Freitas, 2015).

Os microrganismos patogênicos que causam doenças transmitidas por alimentos são divididos em dois grupos, os que levam a quadros infecciosos que compreendem bactérias, como a salmonella, e microrganismos do grupo dos coliformes como a E.coli; e os que causam intoxicação, como Staphylococcus aureus. 0 primeiro grupo agrupa os microrganismos que se multiplicam no trato intestinal, e segundo grupo diz respeito aos microrganismos que produzem toxinas, tanto no alimento, como no trato intestinal, esses microrganismos quando presentes nos alimentos são responsáveis pela maioria das doenças de transmissão alimentar (Forsythe, 2013).

A resolução de número 12, de 02 de Janeiro de 2001, traz os níveis microbiológicos toleráveis em alimentos, visando à proteção a saúde dos consumidores. De a acordo com a resolução, a Salmonella deve ser ausente em alimentos como o queijo coalho, a presença de Staphylococcus coagulase positiva tem limite de tolerância de $5 \times 10^{2}$ e para coliformes a $45^{\circ} \mathrm{C}$, o nível de tolerância e de $5 \times 10^{2} \mathrm{NMPg}$ (Brasil, 2001).

Diante dos riscos que o consumo de alimentos contaminados pode trazer para a população, objetivou-se analisar as características microbiológicas do queijo coalho com e sem registro, comercializado na cidade de Serra Talhada-PE, para a ocorrência de coliformes termotolerantes, Staphylococcus aureus e Salmonella, visto que esse tipo de produto é amplamente comercializado e consumido no município.

\section{MATERIAL DE MÉTODOS}

O município de Serra Talhada está localizado na mesorregião do sertão Pernambucano, com uma população de estimada de 85,774 habitantes, a zona urbana é dividida em 17 bairros (IBGE, 2019). As amostras foram coletadas em mercados, supermercados e no mercado público da cidade, pontos estes distribuídos em todos os bairros da cidade. Foram coletadas 20 amostras de queijos coalho nos períodos de junho de 2018 (período seco, $\mathrm{n}=10$ ), e janeiro de 2019 (período chuvoso, $\mathrm{n}=10$ ), sendo cinco amostras de queijo com registro (Selo de Inspeção Federal-S.I.F, n=3; e Selo de Inspeção Estadual- S.I.E, n=2) e cinco sem registro em cada período, respectivamente. As amostras foram coletadas e armazenadas em caixa isotérmica.

A coleta se deu conforme os queijos eram adquiridos pelo consumidor final (em peças de $\pm 500 \mathrm{~g}$ ), ou seja, pela compra direta do produto, a fim de que os resultados encontrados demostrassem o mais próximo possível o que a população geral da cidade em questão vem consumindo. Em seguida foram levadas para o Laboratório de Microbiologia da Universidade Federal Rural de Pernambuco/ Unidade Acadêmica de Serra Talhada, para realização das análises. No preparo das amostras para inoculação no meio de cultura, foi retirada uma alícola de 25 gramas, fracionados no menor tamanho possível com o auxilio de facas de cozinha, previamente esterilizadas, transferido para um Erlenmeyer contendo $225 \mathrm{ml}$ de água destilada, esterilizada, sendo homogeneizada a solução por cerca de um minuto, em seguida feito a inoculação nos meios de cultura.

Para o teste presuntivo de coliformes totais, foi utilizada a série de diluição de três tubos, $10^{-1} 10^{-2}$ e $10^{-3}$, contendo caldo Lauril, sendo pipetado $1000 \mu$ l, da solução, com o auxilio de um pipetador automático dentro de cada tubo, seguindo para estufa a $35^{\circ} \mathrm{C}$ por 24 horas. Os tubos positivos seguiram para o teste confirmativo, sendo transferidos, com o auxilio de uma alça bacteriológica para o caldo verde brilhante, incubados em estufa a $35^{\circ} \mathrm{C}$ por 24 horas. Os tubos positivos seguiram para quantificação de coliformes termotolerantes, em caldo EC, incubados em estufa a $45^{\circ} \mathrm{C}$, por 48 horas, cujo método utilizado para contagem foi o Número Mais Provável (NMP/g) (Silvaet al., 2017). 
Para detecção de Staphylococcus aureus, foram utilizados placas de petri, sendo as análises realizadas em triplicata utilizando o meio de cultura Agar Baird Parker. Com o auxilio de um pipetado automático, foram inoculados $100 \mu \mathrm{L}$ da solução nas placas, e com o uma alça drigalski, espalhado sobre o meio de cultura, e em seguida as amostras seguiram para incubação em estufa bacteriológica a 35으 por 24 horas (Silvaet al., 2017).

Para detecção de salmonella, foi utilizado o meio de cultura Agar Salmonella Shigella, sendo as analises realizadas em triplicata, utilizando-se placas de petri, onde foi espalhado sobre o meio de cultura $100 \mu \mathrm{L}$ da amostra com o auxilio de uma alça drigalski, seguido para estufa a $35^{\circ} \mathrm{C}$ durante 24 horas. Sendo os resultados para essa análises expressos em presença e ausência, conforme a legislação (Silvaet al., 2017).

Todos os resultados obtidos foram descritos utilizando-se análise estatística descritiva, devido a diversidade de dados (Sampaio, 2007).

\section{RESULTADOS E DISCUSSÃO}

Os resultados para análise e quantificação de coliformes termotolerantes, estão descritos na Tab.1. A resolução de número 12 de 02/01/2001, apresenta limite de tolerância para coliformes a $45^{\circ} \mathrm{C}$ de $5 \times 10^{2}$ $\mathrm{NMP} / \mathrm{g}$ (Brasil,2001). Dos queijos com registro coletados no período seco, $60 \%$ estavam contaminados com valores superiores ao permitido pela legislação (S.I.F =33,3\% e S.I.E= 100\%). Para as amostras sem registro, $80 \%$ apresentaram esse mesmo resultado quanto à contaminação. No período chuvoso, 100\% dos queijos, com e sem registro, estavam contaminados com valores superiores, ocorrendo um aumento bastante significativo entre um período e outro, enfatizando a importância da fiscalização recorrente, visto que os queijos são alimentos perecíveis, devendo serem adotadas medidas higiênico-sanitárias em toda a cadeia produtiva do leite.

A presença dos coliformes termotolerantes em analises de alimentos é indicativa de contaminação fecal, pois essas bactérias têm baixa capacidade de colonização do ambiente, habitando o trato intestinal de animais de sangue quente (Marouelli et al., 2014). Santanna et al. (2008) constataram que 93,3\% das amostras de queijo coalho comercializadas no mercado central da cidade de Aracajú- SE, encontravam-se fora do limite estabelecido pela legislação, resultado semelhante ao trabalho em questão. Oliveira et al., (2010) analisando queijo coalho comercializado no município do Cabo de Santo Agostinho-PE, conclui-o que 80,95\% das amostras apresentaram resultado positivo para coliformes termotolerantes. Quando analisados separadamente, 76,47\% dos queijos com S.I.E estavam acima do limite, e 100\% das amostras com S.I.Fe sem selo estavam com níveis de contaminação superior ao estabelecido pela legislação.

Tabela 1: Quantificação de coliformes termotolerantes em MPN/g, das amostras de queijo coalho, com e sem registro, comercializados em Serra Talhada-PE

\begin{tabular}{|c|c|c|c|c|}
\hline \multirow{3}{*}{$\mathrm{NMP} / \mathrm{g}$} & \multicolumn{4}{|c|}{ Período Seco } \\
\hline & S.I.F. & S.I.E. & \multicolumn{2}{|c|}{ Sem registro } \\
\hline & $\mathrm{N}^{\circ} \quad \%$ & $\mathrm{~N}^{\circ} \quad \%$ & $\mathrm{~N}^{\circ}$ & $\%$ \\
\hline 0a $9,2 \times 10^{0}$ & $2 \quad 66,7$ & 0 & 1 & 20 \\
\hline$\geq 1,1 \times 10^{3}$ & 33,3 & 2100 & 4 & 80 \\
\hline \multirow{2}{*}{ NMP/g } & \multicolumn{4}{|c|}{ Período Chuvoso } \\
\hline & $\mathrm{N}^{\circ} \quad \%$ & $\mathrm{~N}^{\circ}$ & $\mathrm{N}^{\circ}$ & $\%$ \\
\hline 0a $9,2 \times 10^{0}$ & 0 & 0 & 0 & 0 \\
\hline$\geq 1,1 \times 10^{3}$ & 100 & 2100 & 5 & 100 \\
\hline
\end{tabular}

0 resultado para a análise de Staphylococcus aureus foi negativo para $100 \%$ das amostras, não sendo encontrada a presença da bactéria, nos queijos. A legislação determina que o limite para a presença de Staphylococcus coagulase positiva seja de $5 \times 10^{2}$, estando os resultados encontrados dentro do permitido pela legislação (Brasil,2001). Resultados diferentes foram encontrados por Borges et al.,(2008) analisando toda a cadeia de produção do queijo coalho em uma indústria de laticínio localizada em Fortaleza-CE, onde 
em $100 \%$ das amostras foi detectado a presença da bactéria com níveis acima do recomendado pela legislação.

Nas análises para a detecção de Salmonella, 10\% dos queijos sem registro, obtiveram resultado positivo para a presença da bactéria no período seco, nas amostras com S.I.E e S.I.F, a Salmonella foi ausente, como mostra a Tab. 2. No período chuvoso, $66,7 \%$ dos queijos com registro (todos com S.I.F.) e $60 \%$ dos queijos sem registro, estavam contaminados. A resolução de número 12 de 02/01/2001 estabelece que o queijo coalho deva ser ausente de Salmonella (Brasil, 2001). A presença dessa bactéria no queijo coalho coloca em risco a segurança alimentar da população, o consumo de alimento contaminado pode afetar de maneira negativa a saúde dos consumidores.

A alta umidade presente no período chuvoso propicia a maior disseminação de contaminantes, como também o aumento de sujidades presente no úbere dos animais, o que dificultam a assepsia, podendo contaminar o leite (Fonsecae Santos, 2001). A higienização dos equipamentos e utensílios na ordenha assim como dos responsáveis pela manipulação do leite, deve ser realizada de forma criteriosa. Para os queijos analisados observa-se um aumento na contaminaçãodo período seco para ochuvoso, tanto para a presença de coliformes termotolerantes, como para a Salmonella. Em toda a cadeia de produção as normas higiênicas sanitárias devem ser cumpridas, pois a qualidade final do produto está diretamente ligada à qualidade do leite.

A presença de Salmonella em queijo coalho é recorrente, havendo vários relatos, principalmente em queijo coalho artesanal (Borgeset al., 2003; Duarte et al., 2005; Sousaet al., 2014). Resultados também altos, foram relatados por Bezerra et al., (2017), onde 40\% das amostras de queijo coalho comercializada na feira livre de Sousa-PB, tiveram resultado positivo para a presença de Salmonellla.

Tabela 2: Resultados para analise de Salmonella, dos queijos coalho com e sem registro, comercializados em Serra Talhada-PE

\begin{tabular}{|c|c|c|c|}
\hline \multicolumn{4}{|c|}{ Período seco } \\
\hline & S.I.F & S.I.E & Sem registo \\
\hline & $\mathrm{N}^{\circ} \quad \%$ & $\mathrm{~N}^{\circ} \quad \%$ & $\mathrm{~N}^{\circ} \quad \%$ \\
\hline Ausência & 3100 & $2 \quad 100 \%$ & $4 \quad 90 \%$ \\
\hline Presença & 0 & 0 & $110 \%$ \\
\hline \multicolumn{4}{|c|}{ Período chuvoso } \\
\hline & $\mathrm{N}^{\circ} \quad \%$ & $\mathrm{~N}^{\circ} \quad \%$ & $\mathrm{~N}^{\circ}$ \\
\hline Ausência & 33,3 & 2100 & 40 \\
\hline Presença & $2 \quad 66,7$ & 0 & 60 \\
\hline
\end{tabular}

Os serviços de Inspeção Federal e Estadual atuam em parceria com o Departamento de Inspeção de Produtos de Origem Animal (DIPOA), e tem a finalidade de certificar a qualidade dos produtos de origem animal, a fim de garantir a segurança alimentar da população (MAPA, 2018). Os resultados das análises mostram que mesmo os estabelecimentos que são regulamentados, apresentam falhas sanitárias em alguma parte do seu processo de produção, disponibilizando para o mercado consumidor um produto com alta carga microbiana. No referido trabalho, para ambas as amostras (com ou sem registro) assim como períodos (seco e chuvoso) o produto em questão não está apto para o consumo humano, podendo ser um grande risco de saúde pública para o município.

Os queijos são alimentos perecíveis que devem ser armazenado na temperatura adequada. Segundo Resolução № 065/2005, que trata do Regulamento da Inspeção Sanitária e Industrial para Leite e seus Derivados,o queijo fresco deve ser armazenado a uma temperatura de $5^{\circ} \mathrm{C}$ (Brasil, 2005). Os queijos analisados estavam armazenados a uma temperatura superior, estando os queijos com registro no período seco e chuvoso armazenados a uma temperatura média de 8,64 e $13,42^{\circ} \mathrm{C}$, respectivamente. Já os sem registro estavam a temperaturas de $19^{\circ} \mathrm{C}$ no período seco, e $20,72^{\circ} \mathrm{C}$ no período chuvoso, sendo alguns desses queijos comercializados em temperatura ambiente, o pode favorecer a multiplicação de microrganismos, fato esse que pode ter influenciado nos resultados das analises microbiológicas. 


\section{CONCLUSÃO}

O queijo coalho comercializado na cidade de Serra Talhada- PE encontra-se impróprio para o consumo baseado na legislação vigente.

\section{REFERÊNCIAS}

[1] BEZERRA, D. E.L.; SILVA FILHO, C. R. M.; GOMES, D.J.; JUNIOR, E.B.P. Avaliação microbiológica de queijo de coalho comercializado na feira livre de Sousa - Paraíba. Revista Principia. João Pessoa, v. 37, p.85-91, 2017.

[2] BORGES, M F.; FEITOSA, T.; NASSU, R.T. et al. Pesquisa de Salmonela sp. Listeriasp. e microrganismos indicadores higiênico-sanitários em queijos produzidos no estado do Rio Grande do Norte. Ciênc. Tecnol. Aliment, Campinas, p 162-165. 2003.

[3] BORGES, M.F.; NASSU, R.T.; PEREIRA, J.L. et al. Perfil de contaminação por Staphylococcus e suas enterotoxinas e monitorização das condições de higiene em uma linha de produção de queijo de coalho. Ciência Rural, Santa Maria, v.38, p.1431-1438, ago. 2008.

[4] BRASIL. Ministério da Saúde. Agência Nacional de Vigilância Sanitária. p 37, 2001. Resolução RDC número 12, de 02/01/2001. Regulamento Técnico Sobre os Padrões Microbiológicos para Alimentos. Diário Oficial da República Federativa do Brasil, Brasília, 2001. p.37.

[5] BRASIL. Instrução Normativa № 68 de 12 de dezembro de 2006. Métodos Analíticos Oficiais Físico-Químicos para Controle de Leite e Produtos Lácteos. Diário Oficial da República Federativa do Brasil, Brasília, DF, 2006.

[6] BRASIL. Regulamento da inspeção sanitária e industrial para leite e seus derivados. 2005. 16 p.

[7] DUARTE, D.A.M.; SCHUCH, D.M.T.; SANTOS, S.B. et al. Pesquisa de ListeriaMonocytogenes e microrganismos indicadores higiênico-sanitários em queijo de coalho produzido e comercializado no estado de Pernambuco. Arq. Inst. Biolarq, São Paulo, v. 72, n. 3, p.297-302, 2005.

[8] FREITAS, M.P. Avaliação microbiológica de queijos artesanais produzidos na cidade de Taió, Santa Catarina. Saúde Meio Ambient, Santa Catarina, v. 4, n. 2, p. 103-114, jul./dez. 2015.

[9] FORSYTHE, S.J. Microbiologia da segurança dos alimentos. 2.ed. Porto Alegre: Artmed, 2013.1

[10] FONSECA, L.F.L.; SANTOS, M.V. Qualidade do leite e controle da mastite. São Paulo: Lemos editorial, 2001. $175 \mathrm{p}$.

[11] INSTITUTO BRASILEIRO DE GEOGRAFIA E ESTATÍSTICA. IBGE cidades. Disponível em:<https://cidades.ibge.gov.br/brasil/pe/serra-talhada/panorama>. Acessado em: 25 de Jul. 2019.

[12] MAPA. Ministério da Agricultura Pecuária e Abastecimento. Disponível em: < http://www.agricultura.gov.br/assuntos/inspecao/produtos-animal/si f $>$. Acesso em: 05 Jul. 2018.

[13] MAROUELLI, W.A.; MALDONADE, I.R.; BRAGA, M.B.; SILVA, H.R. Qualidade e segurança sanitária da água para fins de irrigação. Edição. Brasília: EMBRAPA, 2014. 20 p.

[14] NASSU, R. T.; MACEDO, B.A.; LIMA, M.H.P. Queijo de Coalho . 1 edição.ed Basilia: EMBRAPA, 2006. 45 p.

[15] OLIVEIRA, K. A.; EVÊNCIO NETO, J.; PAIVA, J.E. MELO, L.E.H.Qualidade microbiológica do queijo de coalho comercializado no município do Cabo de Santo Agostinho, Pernambuco, Brasil .Arq. Inst. Biol., São Paulo, v.77, n.3, p.435-440. 2010.

[16] SANTANNA, R. F.;SANTOS, D.M. MARTINEZ, A.C.C. LIMA, Á.S. Qualidade microbiológica de queijo-coalho comercializado em Aracaju, SE. Arq. Bras. Med. Vet. Zootec., v.60, n.6, p.1517-1522, 2008.

[17] SILVA, N.; JUNQUEIRA, V.C.A.; SILVEIRA, N.F.A.et al. Manual de Métodos de Analise microbiológica de Alimento e Água. 5. ed. São Paulo: Blucher, 2017. 40 p.

[18] SOUSA, A. Z. B.; ABRANTES, M. R.; SAKAMOTO, S. M.et al. Aspectos físico-químicos e microbiológicos do queijo tipo coalho comercializado em estados do Nordeste do Brasil. Arq. Inst. Biol. São Paulo, v.81, n.1, p. 30-35, 2014. 


\section{Capítulo 3}

Análise da presença de amido em queijos do tipo manteiga comercializados em Sousa-PB

\section{Grazielly Mirelly Sarmento Alves da Nóbrega \\ Naiara Menezes Bezerra \\ Mateus Gonçalves Silva \\ José Ramon Afonso da Silva \\ Amanda Raquel Guerreiro Maia \\ Suely Cristina Pereira de Lima Oliveira}

Resumo: Os queijos de manteiga são tipos de produtos lácteos muitos susceptíveis a fraudes por adição de amido, pois o mesmo quando utilizado diminui a quantidade de matéria prima necessária para o processamento do produto alimentício, que no caso é o leite. Os clientes que adquirem queijos vendidos em supermercados, comércio ambulantes ou feiras livres são sujeitos de tais manipulações que ocorrem no processamento desse alimento. Portanto objetivou-se com o presente estudo verificar a presença/ausência de amido em 10 diferentes marcas de queijos do tipo manteiga comercializados na cidade de Sousa-PB, averiguando a ocorrência de fraude. Para identificar a incidência de amido utilizou-se o teste de reação ao Lugol. Em relação a análise, foi constatado a presença de amido em 30\% das amostras (marcas) avaliadas, estando estas em desacordo com a legislação vigente. Diante dos resultados evidenciados, torna-se necessária uma melhoria no sistema de vigilância e fiscalização do comércio geral de produtos alimentícios na cidade de Sousa-PB, com o intuito de garantir a confiabilidade e segurança dos produtos aos consumidores.

Palavras-Chave: Adulterações em alimentos, controle de qualidade, fraudes. 


\section{INTRODUÇÃO}

O queijo é um dos produtos alimentícios de processamento básico mais diversificado que existe. São mais de mil tipos de queijos, fabricados por meio das mais diversas tecnologias e leites de espécies diferentes. É um dos alimentos preparados mais antigo que se conhece (MONTEIRO et al., 2011). Define-se queijo como um derivado do leite ou também como um concentrado lácteo, gorduroso e proteico, que é apreciado por causa de seu alto valor nutricional. Contém quantidades elevadas de proteínas, cálcio, fósforo e vitaminas A e D (LAVASANI et al., 2012). Por meio dessas características que o queijo é produzido e consumido por toda parte do mundo.

0 queijo de manteiga, também conhecido como requeijão do Sertão, requeijão do Nordeste e requeijão do Norte, possui origem brasileira, de grande aceitação nas regiões Norte e Nordeste do Brasil. Este tem sido uma das opções mais utilizadas para aproveitamento de leite nas fazendas situadas longe dos centros consumidores e das agroindústrias de laticínios. É um produto que apresenta fabricação simples e valor nutritivo indiscutível (CAVALCANTE e COSTA, 2005).

Pela legislação brasileira (BRASIL, 2001), entende-se por queijo de manteiga: o produto obtido mediante coagulação do leite com emprego de ácidos orgânicos de grau alimentício, cuja massa é submetida à dessoragem, lavagem e fusão, com acréscimo exclusivamente de manteiga de garrafa ou manteiga da terra ou manteiga do sertão. Este é um queijo com teor de gordura nos sólidos totais variando entre $25 \%$ e $55 \%$, devendo apresentar um teor máximo de umidade de $54,9 \% \mathrm{~m} / \mathrm{m}$.

Muitos dos produtos alimentares ainda são produzidos de acordo com antigas práticas (COKAL et al. 2012), um desses alimentos é o queijo, um derivado lácteo muito apreciado, porém que está facilmente susceptível a adulteração.

O queijo de manteiga está entre os queijos mais produzidos e consumidos do Nordeste brasileiro. Apesar da sua popularidade, há uma diversificação na sua fabricação (GUERRA e GUERRA, 2003, NASSU et al., 2003, CAVALCANTE e COSTA, 2005), quando fabricado de modo empírico, esse queijo é produzido como forma de aproveitamento do leite coagulado espontaneamente pela ação da microbiota láctica natural (VAN DENDER et al., 2006). A deficiência de informações acerca dos atributos de queijos de manteiga pelo Regulamento Técnico de Identidade e Qualidade de Queijo de Manteiga (BRASIL, 2001) dificulta a caracterização e facilita ações de fraude nesse produto alimentício, favorecendo a prática de adulterações.

Geralmente a fabricação do queijo é um processo empírico passado de geração para geração, em que se vão modificando técnicas e incorporando novos ingredientes que de modo geral não são apropriados para o produto e com isso acaba por causar a descaracterização do queijo e consequentemente sua originalidade, qualidade, durabilidade e segurança (LEITE, 2018).

Conforme Nassu et al. (2003) a demanda de consumidores por queijos de manteiga é muito grande e exigente, portanto se têm buscado métodos que melhorem o aspecto visual do produto e dificultem a visualização da introdução parcial ou total de alguns ingredientes não comuns a esse produto, caracterizando-se assim um sistema de fraude. Segundo Reissig (2009) um dos meios de fraude mais utilizados é o método de adição de substâncias que são elementos estranhos aos produtos alimentícios a serem produzidos, e o principal objetivo dessa forma de fraude é aumentar o peso do alimento ou o seu volume.

Uma das adulterações mais comuns que ocorre em queijos é a adulteração por meio da adição de amido, utilizado para aumentar o volume e espessamento do leite (EVAGELISTA 1989), podendo assim ludibriar os consumidores.

No entanto, segundo Cassimiro et al., (2015) a prática de adição de amido aos produtos alimentícios pode ser detectada através de um indicador químico, chamado Lugol (Tintura de Iodo a $2 \%$ ) cuja qual pode ser adicionada a amostras de alimentos como por exemplo aos queijos, a fim de verificar a ocorrência da fraude.

Esse trabalho teve por objetivo verificar a presença/ausência de amido em 10 diferentes marcas de queijos do tipo manteiga comercializados na cidade de Sousa-PB, a fim de identificar possível fraude nesses produtos. 


\section{MATERIAL E MÉTODOS}

Foram obtidas 10 amostras de diferentes marcas de queijos do tipo manteiga comercializados em feiras, supermercados, vendedores ambulantes e varejos na cidade de Sousa-PB. As amostras foram sigilosamente identificadas com letras consecutivas de A-J e posteriormente levadas para o laboratório de análises físicoquímica do Instituto Federal da Paraíba-Campus Sousa, onde realizaram-se os testes. A pesquisa foi conduzida no período de agosto a setembro de 2019.

0 teste de presença/ausência de amido seguiu a metodologia proposta por Cassimiro et al. (2015), onde os queijos obtidos foram analisados por meio da utilização do indicador químico Lugol (Tintura de Iodo a 2\%). O indicador foi cotejado três gotas em cada pedaço de queijo de manteiga e a confirmação da presença do amido foi de forma imediata, pois quando se atinge a superfície do queijo, se houver presença de amido, a região que contendo as cotejações fica azul, confirmando assim a fraude no queijo.

\section{RESULTADOS E DISCUSSÃO}

A qualidade dos alimentos é fator imprescindível para garantia de confiabilidade e bem-estar dos consumidores. As fraudes em produtos alimentícios é um problema que vêm cada vez mais ganhando espaço, sendo necessária a detecção de produtos fraudados e de qualidade inferior no mercado (EGITO et al., 2006). Os queijos estão susceptíveis a fraudes relacionadas a adição de amido à sua formulação.

Através dos métodos empregados obtiveram-se os seguintes resultados para a deteç̧ão de amido em amostras de queijos do tipo manteiga comercializados em Sousa-PB: das 10 (dez) amostras de queijo analisadas, $30 \%$ (amostras $\mathrm{C}, \mathrm{F}$ e $\mathrm{H}$ ) continham certas quantidades de amido em sua composição, fato evidenciado pela presença da cor azul resultante da aplicação da substância indicadora Lugol, assim constatando-se a presença de fraude em alguns queijos de manteigas comercializados na região (Tabela 1).

Tabela 1. Resultados da análise de presença de amido em queijos de manteigas comercializados em SousaPB. 2019.

\begin{tabular}{|c|c|}
\multicolumn{2}{|c|}{ Amostra de Queijos } \\
(Marcas) & Presença de amido \\
\hline A & Ausente \\
\hline B & Ausente \\
\hline C & Presente \\
\hline D & Ausente \\
\hline E & Ausente \\
\hline F & Presente \\
\hline G & Ausente \\
\hline H & Presente \\
\hline I & Ausente \\
\hline J & Ausente \\
\hline
\end{tabular}

Pesquisando sobre detecção de fraudes por adição de amido em diferentes tipos de queijos comercializados em alguns estabelecimentos da cidade de Campina Grande-PB, Cassimiro et al. (2016) encontram resultados semelhantes ao desta pesquisa para o queijo do tipo manteiga, onde $30 \%$ das 10 amostras avaliadas apresentavam em sua composição quantidades de amido. Também para o queijo do tipo ralado, os mesmos pesquisadores encontram fraudes por adição de amido em 5 das 12 amostras averiguadas. Diferente dos resultados para esses dois tipos, os dados para as amostras do queijo coalho não evidenciaram fraudes por adição de amido em nenhuma das 10 amostras analisadas.

Filho et al. (2018) analisando fraudes de queijos de diferentes regiões da Paraíba, verifica fraudes por adição de amido em queijos do tipo manteiga comercializados em Pocinhos-PB e Juazeirinho-PB, correspondendo a 4 das 5 avaliadas e 5 das 5 , respectivamente. 
Avaliando a detecção de amido em queijos do tipo prato e mozarela, Teixeira et al. (2014) observam a adição de diferentes quantidades do carboidrato nos dois tipos de queijos, quantidades essas que variam conforme as marcas avaliadas pelos pesquisadores. Resultados esses evidenciam a realização de fraudes e a exposição dos consumidores a produtos de qualidade inferior e duvidosa. Marques et al. (2016) também detectam a incidência de amido em queijos ralados do tipo parmesão adquiridos em Caxias do Sul-RS. Resultados semelhantes foram encontrados por Ribeiro et al. (2012) que, de 8 amostras de queijo ralado analisadas, uma apresentou resultado positivo. Duarte et al. (2006) analisaram 120 amostras e 6 foram positivas para a presença de amido, caracterizando fraude no produto. Pesquisas como esta permitem transmitir informações sobre a crescente e preocupante ocorrência de fraudes em produtos alimentícios das mais variadas categorias.

Apesar da presença do amido não categorizar problemas à saúde dos consumidores, é um produto que não faz parte do processo de fabricação de queijos, caracterizando-se assim uma fraude econômica, pois permite a substituição de uma matéria prima essencial por uma de menor valor agregado (TEIXEIRA et al., 2014).

De acordo com a legislação brasileira vigente, é considerado fraude, a adição de água, adição de substâncias conservadoras ou de quaisquer elementos estranhos à sua composição do produto de origem animal, isso aplica-se ao queijo. Desse modo, a adição de amido nos produtos analisados está em desacordo com a Lei 8078/90 do Ministério da Justiça, que define como fraude as modificações provocadas intencionalmente com finalidade de lucros que afeta, além dos caracteres organolépticos, o valor nutritivo do alimento (BRASIL, 1990).

\section{CONCLUSÕES}

Através dos resultados obtidos pela pesquisa, conclui-se que algumas marcas ( $\mathrm{C}, \mathrm{F}$ e H) de queijos de manteigas comercializados na cidade de Sousa-PB apresentaram adulteração pela presença de amido na sua composição.

A ação de órgãos fiscalizadores de fraudes em alimentos se faz necessária a fim de estabelecer melhor garantia de qualidade/confiabilidade para os consumidores, visto que são os principais alvos da exposição a produtos de baixa qualidade/adulterados.

\section{AGRADECIMENTOS}

Agradecer ao Instituto Federal da Paraíba-Campus Sousa pelo apoio técnico e suporte financeiro para concretização desta pesquisa, aos colaboradores, a disponibilização do laboratório.

\section{REFERÊNCIAS}

[1] BRASIL. Ministério da Agricultura, Pecuária e Abastecimento. Instrução Normativa no 30, de 26 de junho de 2001. Regulamento Técnico de Identidade e Qualidade de Queijo de Manteiga. Diário Oficial da União, Brasília, DF, 16 jul. 2001.

[2] BRASIL. CONGRESSO NACIONAL. Código de Defesa do Consumidor. Lei no 8078, de 11 de setembro de 1990.

[3] CASSIMIRO, L. M.; LIMA FILHO, J. A.; SOUZA, R. L.; CASSIMIRO, A. K. Análise e comparação da presença ou ausência de amido em três tipos de queijos comercializados em alguns estabelecimentos da cidade de Campina Grande-PB. In: Anais do I Congresso Internacional da Diversidade do Semiárido (I CONIDES), Campina Grande-PB, 2016.

[4] CASSIMIRO, L. M.; SOUZA, R. L.; BRAGA, R. A.; LIMA FILHO, J. A. Aula prática para detecção da presença ou não de amido em dois tipos de queijos comercializados na Feira Central de Campina Grande-PB. In: Anais do II Congresso Nacional de Educação (II CONEDU). Campina Grande-PB, 2015.

[5] CAVAlCANTE, A. B. D.; COSTA, J. M. C. Padronização da Tecnologia de Fabricação do Queijo de Manteiga. Revista Ciência Agronômica. v. 36, n. 2, p. 215-220, mai/ago. 2005.

[6] COKAL, Y.; DAGDELEN, A.; CENET, O.; GUNSEN, U. Presence of L. monocytogenes and some bacterial pathogens in two Turkish traditional foods, Mihalic cheese and Hosmerim dessert. Food Control, v.26, p.337-340, 2012.

[7] DUARTE, A. M.; CRUZ, A. G.; SANT'ANA, A. S.; BARBIN, D. F. Incidência de amido em queijo parmesão ralado. Rev Inst Latic Cândido Tostes, n.353, v.61, p.16-18, 2006. 
[8] EGITO, A. S.; ROSINHA, G. M. S.; LAGUNA, L. E.; MICLO, L.; GIRARDET, J. M.; GAILLARD, J. L. Método eletroforético rápido para detecção da adulteração do leite caprino com leite bovino. Arq Bras Med Vet Zootec. v.58, n.5, p.932-939, 2006.

[9] EVANGELISTA J. Tecnologia de alimentos. São Paulo: Atheneu; 1989.

[10] GUERRA, T. M. M.; GUERRA, N. B. Influência do sorbato de potássio e do tipo de embalagem sobre a vida útil do queijo de manteiga (requeijão do Norte). Brazilian Journal of Food Technology, v.6, p.259-265, 2003.

[11] LAVASANI, A. R. S.; EHSANI, M. R.; MIRDAMADI, S.; MOUSAVI, M. A. E. Z. Changes in physicochemical and organoleptic properties of traditional Iranian cheese Lighvan during ripening. International Journal of Dairy Technology, v. 65, n. 1, p. 64-70, 2012.

[12] LEITE, A. I. N. Autenticidade do queijo de manteiga do Seridó por espectroscopia no infravermelho. Dissertação (mestrado profissional) - Universidade Federal de Juiz de Fora, Faculdade de Farmácia e Bioquímica. Programa de Pós-Graduação em Ciência e Tecnologia do Leite e Derivados, 95p. 2018.

[13] LIMA FILHO, J. A.; SILVA, M. P.; BARBOSA, M. S. Contextualizando as aulas práticas de bioquímica de detecção ou não de amido, a partir da análise em tipos de queijos comercializados em municípios da Paraíba. In: Anais do III Congresso Nacional de Pesquisa e Ensino em Ciências (III CONAPESC), Campina Grande-PB, 2018.

[14] MARQUES, S. F.; CORÇÃO, G.; ALVES, M. K. Análise microbiológica e incidência de amido em queijos ralados. Higiene Alimentar, v.30, n. 256/257, p.100-104, Maio/Junho de 2016.

[15] MONTEIRO, A. A.; PIRES, A. C. S.; ARAÚJO, E. A. Tecnologia de produção de derivados do leite - Série Didática. 2. ed. Viçosa: UFV, 2011.86 p.

[16] NASSU, R.T., ARAÚJO, R S., GUEDES, C.G.M. \& ROCHA, R.G.A. Diagnóstico das condições de processamento e caracterização físico-química de queijos regionais e manteiga do Rio Grande do Norte. Boletim de pesquisa e desenvolvimento, Embrapa Agroindústria Tropical, Fortaleza, 2003. 24p.

[17] REISSIG G. N. Fraudes em alimentos: tipos e detecção [Monografia]. Pelotas, RS: Universidade Federal de Pelotas; 2009.

[18] RIBEIRO, J. C. B.; CARDOSO, C. R.; ESMERINO, L. A.; SANTOS, R. D.; DEMIATE, I. M.; NOGUEIRA. Qualidade físico-química e microbiológica do queijo parmesão ralado comercializado em Ponta Grossa, Paraná. Rev Inst Latic Cândido Tostes, v. 67, n.387, p.21-29, Jul/Ago, 2012.

TEIXEIRA, M. V.; FRANCEZ, Y.; COLA, A. P.; OLIVEIRA, D. V.; SILVA, E.; MUTRAN, T. J. Detecção da presença de amido em queijos do tipo prato e mozarela. Science in Health. v.5, n.2, p.79-85, maio-ago 2014.

[19] VAN DENDER, A.G.F.; MORENO, I.; SNOW, J.G.M.; SPADOTI, L.M. Análises de Controle. "Requeijão Cremoso e outros Queijos Fundidos: Tecnologia de Fabricação, Controle de Processo e Aspectos de Mercado", 1aㅡ. ed., Fonte Comunicações e Editora Ltda, São Paulo, 2006. 


\title{
Capítulo 4
}

Determinação de compostos bioativos em iogurte de leite de cabra adicionado de polpa de cupuaçu

\author{
Daniela Cavalcante dos Santos Campos \\ Beatriz Oliveira de Souza \\ Viviane Antunes Pimentel \\ Rogério Lopes Xavier \\ Adriana Flach \\ Luiz. Antônio Mendonça Alves da Costa \\ Anderson do Nascimento Silva \\ Lailson Oliveira de Sousa
}

Resumo: 0 cupuaçu (Theobroma grandiflorum) é uma espécie das regiões tropicais e subtropicais, que apresenta grande potencial industrial. 0 leite caprino é rico em gorduras e outros nutrientes, além de ser uma alternativa para pessoas com alergias. Este trabalho teve como objetivo elaborar iogurtes de leite de cabra adicionados de polpa de cupuaçu e avaliar suas características bioativas. 0 leite caprino foi obtido de cabras do setor de produção animal da Escola Agrotécnica (EAgro/UFRR), pasteurizado e acondicionamento refrigerado a $8{ }^{\circ} \mathrm{C}$ até o momento do uso. As avaliações realizadas tanto na polpa de cupuaçu quanto nos iogurtes adicionados de $10 \%$ e $20 \%$ de polpa de cupuaçu foram: fenólicos totais e atividade antioxidante pelo método DPPH. Tanto os fenólicos quanto a atividade antioxidante obtidas nos iogurtes foram inferiores aos valores encontrados para polpa. Os compostos fenólicos e atividade antioxidante mostraram aumento significativo, conforme o teor de polpa de cupuaçu foi aumentado.

Palavras-Chave: Theobroma gradiflorum, atividade antioxidante, produtos lácteos. 


\section{INTRODUÇÃO}

A busca por alimentos que contenham substâncias capazes de melhorar a qualidade de vida das pessoas e que sejam facilmente incorporados à dieta convencional aumentou nos útimos anos (SALGADO, 2017).

Já é conhecido o alto valor nutritivo e os efeitos terapêuticos relacionados ao consumo de frutas e vegetais, e seguindo esta tendência observa-se o aumento no consumo de frutas tropicais nativas da Amazônia. Além disso, também ocorre a expansão da utilização das polpas de frutas congeladas em indústrias de produtos alimentícios em geral aumentando o interesse de produtores e consumidores (KUSKOSKI et al.,2006). Dentre as diversas frutas tropicais nativas da região Amazônia, o cupuaçu é aquela que apresenta as melhores condições de aproveitamento industrial (COSTA et al., 2003), dentre eles, destacam-se no fruto, os componentes que são voláteis e elevam a sua atratividade ( ALVES, 2013).

Obedecendo a demanda de consumo, a indústria de alimentos detém diversas alternativas que podem transformar os frutos in natura em atrativos produtos processados mantendo boa quantidade de compostos funcionais. Nesse sentido, pode-se citar o iogurte, que é elaborado com culturas ativas de bactérias láticas que fermentam o leite, metabolizando parte da lactose presente a ácido lático (VAN DE WATER, 2003).

0 iogurte de leite de vaca é amplamente comercializado e aceito pelo mercado consumidor, entretanto a inserção do leite de cabra na produção de iogurtes pode ser uma alternativa interessante para a obtenção de novos produtos com características nutricionais diferenciadas (maior digestibilidade, menor alergenicidade e maior teor de ácidos graxos poli-insaturados) (SENAKA RANADHEERA, et al., 2012). Estudos mostram que o leite de cabra é superior ao da vaca em termos de cálcio, fósforo, potássio, magnésio e também ao leite humano nos teores de fósforo, sódio e potássio (QUADROS, 2012).

Dessa forma, a agroindustrialização do leite de cabra, pode ser alternativa para consumidores com intolerância a lactose e alergias relacionadas às proteínas do leite, já que apresenta resultados positivos como substituto ao leite de vaca. As diferenças estruturais entre as caseínas alfa-s1 do leite de vaca e de cabra, além da quantidade inferior desta proteína, favorecem o consumo deste leite em detrimento do leite de vaca (LOWRY, 2015).

Portanto, o presente trabalho teve como objetivo, quantificar os fenólicos e a capacidade antioxidante de iogurtes produzidos com leite de cabra adicionados de diferentes concentrações de polpa de cupuaçu.

\section{MATERIAIS E MÉTODOS}

Os frutos do cupuaçuzeiro foram colhidos em pomar particular no município do Caroebe localizado no Sul do Estado de Roraima no período de setembro a outubro de 2014 em estado de maturação. Os frutos foram lavados e escovados em água corrente para retirada das sujidades da casca, para então serem imersos em água clorada a $100 \mathrm{mg} / \mathrm{L}$ por 10 minutos.

Após a sanitização os frutos foram expostos à temperatura e umidade ambiente para retirada do excesso de água, e em seguida foram acondicionados em caixa térmica com gelo e transportados para o Laboratório de Tecnologia de Produtos Agropecuários (LTPA) da Escola Agrotécnica da Universidade Federal de Roraima (EAgro/UFRR). O despolpamento foi realizado manualmente com auxílio de tesoura em aço inoxidável, previamente higienizada em temperatura de $80^{\circ} \mathrm{C}$ por 20 minutos, e a polpa recolhida após a separação das sementes foi pesada (aproximadamente 1,400kg), acondicionada em sacos plásticos com capacidade de $200 \mathrm{~mL}$, pasteurizada a $95 \pm 2{ }^{\circ} \mathrm{C}$ por 2 minutos, resfriada em água corrente e congelada a $-18^{\circ} \mathrm{C}$.

0 leite caprino (2,90 L) foi obtido de cabras da raça Saanen criadas no rebanho de caprinos do setor animal na EAgro/UFRR. A ordenha foi realizada manualmente nas primeiras horas da manhã em local específico para esta finalidade, limpo e arejado próximo ao aprisco dos caprinos. 0 úbere e tetas das cabras foram sanitizadas com solução de iodo a 4\%, enxaguadas com a água em abundância e secos com papel toalha. 0 leite foi recolhido em béquer plástico com capacidade de $1000 \mathrm{~mL}$, previamente higienizado em solução de hipoclorito de sódio a $100 \mathrm{mg} / \mathrm{L}$, e posteriormente acondicionado em garrafas de polietileno tereftalato (PET) com capacidade de $300 \mathrm{~mL}$ e transportado para o LTPA, onde foi pasteurizado a $71 \pm 2{ }^{\circ} \mathrm{C}$ por 15 minutos. Após a pasteurização, as garrafas PET foram dispostas em basqueta plástica com água onde permaneceram em temperatura ambiente $\left(19-22^{\circ} \mathrm{C}\right)$ até atingir o equilíbrio, para então serem armazenadas em incubadora B.O.D TE 371 TECNAL sob-refrigeração a temperatura de $8^{\circ} \mathrm{C}$ até o momento de sua transformação em iogurte.

Os iogurtes foram elaborados com leite de cabra pasteurizado e não padronizado quanto ao teor de gordura, 8\% de açúcar, e 2,5\% de cultura lática presente no fermento Ricaferm YR03 (Ricanata). 0 leite foi aquecido 
até a temperatura de $43 \pm 2^{\circ} \mathrm{C}$, momento em que foi realizada adição da cultura lática contendo Lactobacillus bulgariccus e Streptococcus thermophillus. Após a adição da cultura, o leite foi incubado em banho termotizado a $43 \pm 2^{\circ} \mathrm{C}$, sendo o acompanhamento dos valores de $\mathrm{pH}$ realizados a cada hora até alcançar o valor de 4,6 totalizando 4 horas de coagulação. Os iogurtes de leite de cabra adicionados de polpa de cupuaçu foram codificados como ICBR + CUPU $10 \%$ e ICBR + CUPU $20 \%$. Após a fermentação, o iogurte foi transferido para a incubadora B.O.D, onde permaneceu a $4 \pm 2^{\circ} \mathrm{C}$ por 24 horas e após este período, foram acrescentadas polpas de cupuaçu nas concentrações de $10 \%$ e $20 \%$ (v/p), com homogeneização manual a fim de se realizar a quebra do coágulo.

\subsection{PREPARO DAS SOLUÇÕES ESTOQUE PARA DETERMINAÇÃO DE FENÓLICOS TOTAIS E ATIVIDADE ANTIOXIDANTE PELO MÉTODO DO DPPH}

Aproximadamente $1 \mathrm{~g}$ de polpa de cupuaçu e 2,5 g iogurte com cupuaçu de cada concentração $(10 \%$ e $20 \%$ de polpa) foram homogeneizados em metanol e transferidos para balões volumétricos de $5 \mathrm{~mL}$. Em seguida as soluções metanólicas foram submetidas a sonicação em ultrassom (modelo Unique - $1400 \mathrm{~A}$ ) por 20 minutos e centrifugadas a 3400 RPM também por 20 minutos, sendo o sobrenadante utilizado nas determinações de fenólicos totais e atividade antioxidante.

\subsection{QUANTIFICAÇÃO DE FENÓLICOS TOTAIS}

Para a constituição das soluções contendo os compostos fenólicos, foram tomadas alíquotas em triplicata, $30 \mu \mathrm{L}$ da polpa e dos iogurtes nas concentrações de $10 \%$ e $20 \%, 120 \mu \mathrm{L}$ e $60 \mu \mathrm{L}$ respectivamente, e em seguida adicionado $300 \mu \mathrm{L}$ do reagente de Folin Ciocalteu, $2 \mathrm{~mL}$ de uma solução a $15 \%$ de carbonato de sódio $\left(\mathrm{Na}_{2} \mathrm{CO}_{3}\right)$ e água destilada para aferir os balões volumétricos até volume final de $5 \mathrm{~mL}$, seguindo o método proposto por Genovese; Lannes (2009) com adaptações. As soluções foram transferidas para tubos de ensaio com capacidade de $15 \mathrm{~mL}$ e centrifugadas a 3400 RPM por 5 minutos, em seguida foram mantidas em repouso por duas horas a temperatura ambiente e ao abrigo da luz. A absorbância foi medida a $798 \mathrm{~nm}$ em espectrofotômetro UV-visível (modelo UV- mini - 1240 - Shimadzu) e os resultados obtidos a partir da curva de calibração com ácido gálico e expressos em mg de AGE (ácido gálico equivalente) por $100 \mathrm{~g}$ de amostra.

\subsection{DETERMINAÇÃO DA ATIVIDADE ANTIOXIDANTE PELA CAPTURA DO RADICAL LIVRE DPPH}

A capacidade antioxidante foi determinada através da redução do DPPH pelos antioxidantes presentes nas amostras e quantificada a partir da curva de calibração utilizando o Trolox como padrão de antioxidante (BRAND-WILLIANS et al., 1995; RUFINO et al., 2007) com adaptações.

\subsection{ANÁLISE ESTATÍSTICA}

Para as análises de componentes bioativos, os dados foram submetidos à ANOVA e comparação de médias pelo Teste de Tukey a $95 \%$ de probabilidade estatística, utilizando o programa computacional Sistema para Análise de Variância - SISVAR (FERREIRA, 2010).

\section{RESULTADOS E DISCUSSÕES}

\subsection{FENÓLICOS TOTAIS E ATIVIDADE ANTIOXIDANTE PELO RADICAL LIVRE DPPH}

Em relação aos compostos bioativos, a Tabela 1 apresenta os resultados das médias referentes à quantificação do conteúdo de fenólicos totais, e atividade antioxidante da polpa de cupuaçu e dos iogurtes elaborados. A partir da análise dos dados verificou-se que houve diferença significativa a $5 \%$ de probabilidade entre os valores obtidos para fenólicos totais e atividade antioxidante quando se comparou os iogurtes ICBR + CUPU $10 \%$ e ICBR + CUPU $20 \%$ com a polpa de cupuaçu, assim como se considerou os iogurtes adicionados de polpa nas duas concentrações. Além disso, verificou-se que o aumento no teor de polpa, aumentou o teor de fenólicos e consequentemente, atividade antioxidante dos iogurtes. 
Tabela 1 - Média dos resultados de fenólicos totais e atividade antioxidante da polpa e do Iogurte com Cupuaçu.

\begin{tabular}{|c|c|c|}
\hline Amostras & \multicolumn{2}{|c|}{$\begin{array}{c}\text { Atividade Antioxidante } \mu \text { Mol } \\
\text { TEAC 100g-1 }\end{array}$} \\
\hline Polpa de cupuaçu & $369,22 \mathrm{~A}$ & $1077,02 \mathrm{~A}$ \\
\hline ICBR + CUPU 10\% & $23,66 \mathrm{C}$ & $42,88 \mathrm{C}$ \\
\hline ICBR + CUPU 20\% & $34,17 \mathrm{~B}$ & $113,12 \mathrm{~B}$ \\
\hline
\end{tabular}

Letras maiúsculas diferentes na mesma coluna mostram diferença significativa $(p \leq 0,05)$ a 95\% de confiança.

O valor médio dos compostos fenólicos obtidos foram superiores aos encontrados por Kuskoski et al., (2006), que ao estudarem os componentes fenólicos da polpa de cupuaçu encontraram valor de 20,50 $\pm 3,0$ mg AGE $100 \mathrm{~g}^{-1}$ de peso fresco. As diferenças nos valores de fenólicos podem ser influenciadas por diversos fatores, tais quais maturação, espécie, práticas de cultivo, origem geográfica, estágio de crescimento, condições de colheita e processo de armazenamento das frutas. A peculiaridade metodológica relacionada ao solvente extrator e aos fenólicos usados como padrão para a quantificação dos compostos fenólicos também pode contribuir para as diferenças observadas (SOARES, 2008).

Os fenólicos totais dos iogurtes adicionados de $10 \%$ e $20 \%$ de polpa de cupuaçu foram inferiores aos obtidos na polpa, entretanto, se compararmos os teores de fenólicos encontrados em ambos os iogurtes com outras fontes de componentes fenólicos extraídos com metanol, tais como: cajá, graviola, manga e maracujá $(35,48$, 20,65, 1968 e 6,03 mg catequina 100-1), pode-se verificar que o teor de fenólicos quantificados nos iogurtes adicionados de polpa superaram os encontrados para estas frutas.

Considerando a classificação de Vasco et al., (2008), a polpa de cupuaçu e os iogurtes adicionados de polpa se enquadram como alimentos de médio e baixo teores de compostos fenólicos (baixo <100 mg GAE 100g1) e médio (100 - 500 mg GAE 100g-1).A diferença na classificação da polpa para a dos iogurtes com polpa, se deve as perdas de componentes fenólicos da polpa quando adicionada aos iogurtes, provavelmente relacionadas à formação de espécies reativas de oxigênio, que são neutralizadas por estes componentes, e, portanto, não são mais detectadas pelos métodos analíticos propostos.

Os resultados encontrados para a atividade antioxidante dos iogurtes nas duas concentrações de polpa foram inferiores à encontrada para o fruto, equivalendo aos resultados obtidos na quantificação de compostos fenólicos. Entretanto, quando se comparou os resultados obtidos com os de polpa de frutas congeladas estudadas por Kuskoski et al., (2006), verificou-se que a atividade antioxidante dos iogurtes adicionados de polpa de cupuaçu mantiveram-se equiparadas a frutas como: abacaxi, maracujá e uva $\left(21,7,20,0\right.$ e $117,1 \mu \mathrm{M}$ de Trolox $\left.100 \mathrm{~g}^{-1}\right)$ respectivamente.

Mesmo não sendo realizados os estudos de correlação, pode-se observar que à medida que se aumentou o teor de polpa de cupuaçu nas formulações de iogurte, verificou-se um aumento significativo do conteúdo de fenólicos totais, assim como da atividade antioxidante, podendo-se inferir alguma correlação entre estas variáveis.

\section{CONSIDERAÇÕES FINAIS}

0 teor de compostos fenólicos e a atividade antioxidante da polpa de cupuaçu foram superiores as encontradas nos iogurtes adicionados de polpa e, além disso, estas variáveis aumentaram na mesma proporção em que o teor de polpa de cupuaçu foi aumentado nos iogurtes.

Os valores obtidos indicam o iogurte de leite de cabra adicionado de polpa de cupuaçu, como uma boa fonte de antioxidantes. 


\section{REFERÊNCIAS}

[1] ALVES, D. P. Determinação de características físico-quimicas de polpas de cupuaçu (Theobroma grandiflorum Schum) congeladas comercializadas em Ariquemes, Rondônia, Brasil. Monografia, Faculdade de Educação e Meio Ambiente, Ariquemes, Rondônia, Brasil. 2013.

[2]

[3] BRAND-WILLIAMS, W; Cuvelier, M. E; Berset, C. Use of free radical method to evaluate antioxidant activity. Lebensm. Wiss. Technology, 28 (1), 25-30, 1995.

[4] COSTA, M. C. et al. Conservação de polpa de cupuaçu [ Theobroma grandiflorum (Willd. Ex Spreng.) Schum] por métodos combinados. Revista Brasileira de Fruticultura, 25 (2), 213- 215. 2003.

[5] FERREIRA, D. F. Sisvar: A computer statistical analysis system. Ciência e Agrotecnologia (UFLA), 35 (6), 1039 1042. 2010.

[6] GENOVESE, M. I; LANNES, S. C. S. Comparison of total phenolic content and antiradical capacity of powders and "chocolates" from cocoa and cupuassu Ciência e Tecnologia de Alimentos, v 29. n .4 p. 810-814, 2009.

[7] LOWRY, D. (2015). Research puts scientific seal of approval on goat milk. Disponível em:

[8] <http://www.pirineus.ind.br/leitedecabra/pagina23>.Acesso em 29 de abr. 2021.

[9] KUSKOSKI, E. M. et al. Frutos tropicais silvestres e polpas de frutas congeladas: atividade antioxidante, polifenóis e antocianinas. Ciência Rural, 36 (4), 1283-1287. 2006.

[10] QUADROS, D. G. Leite de cabra: produção e qualidade. Bahia: Uneb. 7 p. 2012.

[11] SENAKA RANADHEERA, C. et al. Probiotic viability and physic-chemical and sensory properties of plain and stired fruit yogurts made from goat's milk. Food Chemistry, 135 (3), 1411-1418. 2012.

[12] RUFINO, M. D. M. et al. Bioactive compounds and antioxidant capacities of 18 non-traditional tropical fruits from Brazil. Food Chemistry, 121(4), 996-1002. 2010.

[13] SALGADO, J. Alimentos funcionais. Oficina de Textos, 2017.

[14] SOARES, M. et al. Compostos fenólicos e atividade antioxidante da casca de uvas Niágara e Isabel. Revista Brasileira de Fruticultura, 30 (1) 59-64. 2008.

[15] VAN DE WATER, J. Yogurt and immunity: the health benefits of fermented milk products that contain lactic acid bacteria. In: Farnworth, E. R. (Ed.). Handbook of fermented functional foods. 2003.

[16] VASCO, C.; RUALES, J.; KAMAL-ELDIN, A. Total fenolic compound and oxidant capacitis of major fuits from ecuador . Food Chemistry,111 (4), 816-823. 2008. 


\title{
Capítulo 5
}

\section{Processamento térmico do leite: Termização, pasteurização e UHT}

\author{
Cintia da Silva Araújo \\ Wallaf Costa Vimercati \\ Leandro Levate Macedo \\ Raquel Reis Lima \\ Cintia Tomaz Sant'Ana \\ Solciaray Cardoso Soares Estefan de Paula \\ Magno Fonseca Santos \\ Hygor Lendell Silva de Souza \\ Pedro Henrique Alves Martins \\ Hugo Calixto Fonseca \\ Ramon Ramos de Paula
}

Resumo: 0 leite é um alimento de elevado valor nutricional e sensorialmente agradável, sendo consumido por grande parcela da população, seja na forma fluida ou de seus derivados. Contudo, é um alimento de grande perecibilidade e que necessita da aplicação de métodos que garantam a sua conservação. Os métodos térmicos discutidos a seguir são amplamente aplicados ao leite e diferem, principalmente, em relação a severidade do tratamento. Como consequência disso, os prazos de validade e as características dos produtos obtidos por esses processos são distintos. A qualidade da matéria-prima é de fundamental importância, independentemente do método de tratamento térmico aplicado.

Palavras-chave: leite, processamento, conservação do leite, tratamento térmico. 


\section{TERMIZAÇÃO}

De acordo com o Art. 254 do Regulamento de Inspeção Industrial e Sanitária de Produtos de Origem Animal (RIISPOA), "entende-se por termização ou pré-aquecimento a aplicação de calor ao leite em aparelhagem própria com a finalidade de reduzir sua carga microbiana, sem alteração das características do leite cru" (BRASIL, 2017).

A termização é um tratamento térmico mais brando quando comparado a pasteurização e que, portanto, não inativa a fosfatase alcalina. Nesse caso, é empregado um binômio tempo/temperatura de 63 a $65^{\circ} \mathrm{C} / 15$ segundos ou 60 a $69^{\circ} \mathrm{C} / 20$ segundos, por exemplo (BYLUND, 1995; WALSTRA; WOUTERS; GEURTS, 2006). Esse tratamento é importante quando o leite não pode ser imediatamente processado e precisa ser armazenado. Neste caso, apenas o resfriamento poderia resultar em perda de qualidade da matéria-prima devido ao crescimento microbiano (BYLUND, 1995). O alvo desse tipo de tratamento é reduzir, consideravelmente, os microrganismos psicotróficos que podem produzir lipases e proteases resistentes ao tratamento térmico, e que tem efeito negativo na qualidade dos derivados de leite (FOX; MCSWEENEY, 1998; BENNETT; JOHNSTON, 2004; WALSTRA; WOUTERS; GEURTS, 2006). Após a aplicação da termização, o leite deve ser resfriado a cerca de $4{ }^{\circ} \mathrm{C}$ ou menos visando impedir o desenvolvimento de bactérias formadoras de esporos (BYLUND, 1995).

Um outro efeito decorrente da termização é a possível germinação de esporos. Neste caso, o microrganismo volta a seu estado vegetativo e pode ser inativado na etapa de pasteurização do leite (BYLUND, 1995; SHEEHAN, 2007).

Os microrganismos psicotróficos apresentam uma temperatura ótima de crescimento em torno de 20 a $30{ }^{\circ} \mathrm{C}$, mas também crescem, embora mais lentamente, em temperaturas de refrigeração. A contaminação geralmente ocorre durante os processos de ordenha e armazenamento. A maioria desses microrganismos são gram-negativos e o mais comumente encontrado é o Pseudomonas fluorescens. Contudo, outros microrganismos como Enterobacteriacea, Flavobacterium e Acinetobacter e cepas gram-positivas, em especial do gênero Bacillus, também são encontrados (BERESFORD, 2007).

A termização permite que o leite que chega a uma planta de processamento possa ser armazenado por um período de, aproximadamente, 72 horas e, desta forma, flexibiliza os cronogramas de processamento do leite. No entanto, a eficiência da termização e, consequentemente, o tempo em que o leite poderá ser mantido a baixa temperatura sem efeitos danosos à sua qualidade irá depender da qualidade microbiológica do leite cru, dos parâmetros de temperatura e tempo utilizados para a termização, do resfriamento subsequente do leite e da não recontaminação do produto (SHEEHAN, 2007).

A melhor maneira de se evitar problemas nos derivados de leite causados pelos microrganismos psicotróficos é a adesão às boas práticas durante a ordenha, armazenamento, transporte e fabricação dos derivados, além de reduzir o tempo de armazenamento do leite (BERESFORD, 2007). 0 leite, sempre que possível, deve ser processado em até 24 horas da chegada a planta de processamento e a termização aplicada quando isso não for possível (BYLUND, 1995).

\section{PASTEURIZAÇÃO}

De acordo com o Art. 255 do RIISPOA, "entende-se por pasteurização o tratamento térmico aplicado ao leite com objetivo de evitar perigos à saúde pública decorrentes de micro-organismos patogênicos eventualmente presentes, e que promove mínimas modificações químicas, físicas, sensoriais e nutricionais" (BRASIL, 2017).

A Instrução Normativa ${ }^{\circ} 76$ de 26 de novembro de 2018, por meio dos Regulamentos Técnicos de Identidade e Qualidade (RTIQ), estabelece as características de qualidade que o leite cru refrigerado, leite pasteurizado e leite pasteurizado tipo A devem apresentar (BRASIL, 2018).

De acordo com Art. 12 dessa Instrução Normativa, "leite pasteurizado é o leite fluido submetido a um dos processos de pasteurização previstos na legislação vigente, envasado automaticamente em circuito fechado e destinado a consumo humano direto" (BRASIL, 2018).

o leite pasteurizado tipo A é definido como o "leite fluido, produzido, beneficiado e envasado exclusivamente em Granja Leiteira, submetido a um dos processos de pasteurização previstos na legislação vigente e destinado ao consumo humano direto" (BRASIL, 2018).

O Art. 13 dessa Instrução Normativa diz ainda que "o leite pasteurizado, de acordo com o conteúdo da matéria gorda, é classificado e denominado como: leite pasteurizado integral, leite pasteurizado 
semidesnatado ou leite pasteurizado desnatado". 0 teor de gordura deve ser no mínimo de 3,0g/100g para o leite integral, 0,6 a 2,9g/100g para o semidesnatado e no máximo de 0,5g/100g para o desnatado (BRASIL, 2018).

Conforme Art. 251 do RIISPOA, "o processamento do leite após a seleção e a recepção em qualquer estabelecimento compreende, entre outros processos aprovados pelo Departamento de Inspeção de Produtos de Origem Animal, as seguintes operações: o pré-beneficiamento do leite, compreendidas, de forma isolada ou combinada, as etapas de filtração sob pressão, clarificação, bactofugação, microfiltração, padronização do teor de gordura, termização (pré-aquecimento), homogeneização e refrigeração" (BRASIL, 2017).

0 leite pasteurizado apresenta vida útil de 3 a 6 dias, sob refrigeração. As etapas de produção do leite pasteurizado compreendem o controle da matéria-prima, eliminação de impurezas, pasteurização, refrigeração, acondicionamento, refrigeração e comercialização. A etapa de homogeneização pode estar presente ou não no processo (ORDÓNEZ et al., 2005).

A pasteurização é um tipo de tratamento térmico que pode ser realizado por um longo tempo a baixa temperatura (entre $63 \mathrm{e} 65^{\circ} \mathrm{C} / 30$ minutos) ou a mais alta temperatura por um período de tempo menor. Nesse caso, a temperatura deve ser elevada de 72 a $75^{\circ} \mathrm{C}$ por 15 a 20 segundos, seguido de resfriamento em temperatura não superior à $4{ }^{\circ} \mathrm{C}$ (BRASIL, 2017). Esse processo tem sua eficiência determinada pela inativação da enzima fosfatase alcalina (BYLUND, 1995). Além da fosfatase alcalina inativa, o leite deve apresentar a enzima lactoperoxidase ativa. Essa enzima é mais termorresistente do que a fosfatase alcalina $\left(85{ }^{\circ} \mathrm{C} / 20\right.$ segundos) e assegura que o leite não foi submetido a uma pasteurização drástica (ORDÓNEZ et al., 2005).

0 aquecimento do leite na pasteurização lenta pode ser do tipo direto, ou seja, o recipiente contendo o leite é colocado diretamente sobre uma chama. Indireto, quando é utilizado um trocador de calor, sendo este aquecido por água ou vapor. Injeção de vapor, em que o vapor aquecido é colocado em contato direto com o leite, e por fim, ejeção de vapor, nesse caso, além do aquecimento ocorre uma certa homogeneização do leite (ABREU, 2014).

A pasteurização rápida do leite é obtida a partir de equipamentos que possuem placas metálicas de alta condutividade térmica, os chamados pasteurizadores a placas. Nesse processo, o leite frio troca calor com a água quente por meio de contato indireto. Após ser aquecido, o leite permanece pelo tempo necessário à pasteurização, em uma seção chamada de retardamento. Ao sair do retardamento o leite pode ser considerado pasteurizado. Além disso, o próprio leite que passa pelo pasteurizador aquece o leite que ainda será pasteurizado, tornando o processo mais econômico. Após trocar calor entre o leite quente e o frio (que está entrando no sistema), o leite segue para o resfriamento, seção em que troca calor com água gelada (ABREU, 2014).

O leite pasteurizado é um produto com características de sabor e valor nutritivo semelhantes ao do leite cru. Quando empregado o processo tecnológico adequado, ocorre a destruição de microrganismos patogênicos não esporulados e redução do número de microrganismos deteriorantes (ORDÓNEZ et al., 2005).

Na pasteurização, o binômio tempo/temperatura é suficiente para tornar o produto microbiologicamente seguro por ser eficiente na eliminação de microrganismos patogênicos, como Mycobacterium tuberculosis, Salmonella spp., E. coli, Campylobacter jejuni, e Listeria monocytogenes. Além disso, microrganismos deteriorantes como coliformes, bactérias mesofílicas do ácido lático e psicrotróficos presentes no leite cru são inativados. Alguns microrganismos podem sobreviver ao processo de pasteurização do leite, como os micrococos resistentes ao calor (Microbacterium spp.) e esporos bacterianos. Embora algumas cepas de Staphylococcus aureus também possam sobreviver ao tratamento térmico, elas não crescem a ponto de formar quantidades de toxinas que sejam um risco a saúde (WALSTRA; WOUTERS; GEURTS, 2006). Os esporos de Bacillus cereus são os principais patógenos que sobrevivem à pasteurização e conseguem crescer à baixa temperatura, podendo produzir sabor amargo e deterioração do leite. A intoxicação por esse patógeno, geralmente, não é observada pois neste nível o leite já estaria impróprio ao consumo (LEWIS, 2003).

Para garantir que o leite pasteurizado tenha as melhores propriedades possíveis, é preciso se observar a qualidade do leite cru, o tempo e a temperatura da pasteurização, impedir a recontaminação póspasteurização (o que ocorrer nas seções de regeneração ou refrigeração, em tanques de armazenamento e na embalagem final do devido à falta de práticas de higiene) e manter a temperatura de armazenamento refrigerado (LEWIS, 2003). 
A etapa de homogeneização é importante para evitar a aglomeração de gordura na parte superior da embalagem, durante o armazenamento. A homogeneização, geralmente, é realizada antes da pasteurização para que não ocorra uma recontaminação do produto. Como uma maneira de reduzir os custos nesse processo, apenas a fração contendo a gordura do leite é submetida à homogeneização (WALSTRA; WOUTERS; GEURTS, 2006). Além disso, uma etapa crucial no processamento de leite pasteurizado é o resfriamento, visando tornar o meio desfavorável ao desenvolvimento dos microrganismos que restaram da pasteurização e também para interromper o processo de pasteurização (ABREU, 2014).

\section{UHT}

Conforme definido no Art. 256 do RIISPOA, "entende-se por processo de ultra-alta temperatura - UAT ou UHT o tratamento térmico aplicado ao leite a uma temperatura entre $130{ }^{\circ} \mathrm{C}$ (cento e trinta graus Celsius) e $150{ }^{\circ} \mathrm{C}$ (cento e cinquenta graus Celsius), pelo período de dois a quatro segundos, mediante processo de fluxo contínuo, imediatamente resfriado a temperatura inferior a $32{ }^{\circ} \mathrm{C}$ (trinta e dois graus Celsius) e envasado sob condições assépticas em embalagens esterilizadas e hermeticamente fechadas" (BRASIL, 2017).

Segundo o Regulamento Técnico de Identidade e Qualidade do Leite UAT "de acordo com o conteúdo da matéria gorda, o leite UHT (UAT) classifica-se em: leite UHT (UAT) integral, leite UHT (UAT) semi-desnatado ou parcialmente desnatado e leite UHT (UAT) desnatado". O leite será considerado integral quando tiver em sua composição no mínimo $3 \%$ de gordura, semidesnatado, entre $0,6 \%$ e 2,9\% e desnatado, no máximo $0,5 \%$ de gordura (BRASIL, 1996).

O citrato de sódio, monofosfato de sódio, difosfato de sódio, trifosfato de sódio, separados ou em combinação em uma quantidade não superior a 0,1g/100 ml podem ser adicionados ao leite UHT (BRASIL, 1996).

O processamento UHT é realizado a temperaturas acima de $135^{\circ} \mathrm{C}$ por alguns segundos, visando esterilizar o leite, de forma que quando o produto é embalado em condições assépticas, se torna resistente à deterioração por períodos muito longos. 0 leite UHT é produzido em sistema fechado, onde o leite passa por processos de aquecimento e resfriamento de maneira muito rápida (BYLUND, 1995; KARLSSON et al., 2019).

A esterilização do leite foi implementada com base nos parâmetros térmicos dos esporos de Bacillus stearothermophilis e Bacillus subtilis. As etapas básicas do processamento UHT são o controle da matériaprima, eliminação de impurezas, pré-aquecimento, UHT direto ou indireto, resfriamento rápido, acondicionamento asséptico, armazenamento e comercialização. A etapa de eliminação de impurezas pode ser realizada via centrifugação ou filtração, com o intuito de retirar partículas macroscópicas (ORDÓNEZ et al., 2005).

0 pré-aquecimento tem como função estabilizar termicamente o leite para o processo UHT (FOX; MCSWEENEY, 1998). No processamento comercial de leite UHT, o leite cru é geralmente pré-aquecido de 80 a $95{ }^{\circ} \mathrm{C}$ por 30 a 60 segundos para estabilizar a $\beta$-lactoglobulina, antes do aquecimento em alta temperatura, de 135 a $150^{\circ} \mathrm{C}$, por alguns segundos. 0 pré-aquecimento é importante porque, quando a $\beta$ lactoglobulina desnatura a essas temperaturas mais baixas, ela permanece estável, de modo que não ocorra deposição na seção de aquecimento a alta temperatura (DATTA; DEETH, 2001).

Além desse efeito de estabilização das proteínas do soro, alguns estudos avaliaram diferentes temperaturas e tempos de pré-aquecimento do leite submetido ao tratamento UHT, com o intuito de torná-lo mais estável ao armazenamento. Segundo Stoeckel et al. (2016), o pré-aquecimento em temperaturas de 80 a 95 por um período de 30 a 180 segundos antes do processamento UHT pode reduzir a atividade da plasmina, aumentando a estabilidade do leite. 0 mesmo foi observado por Newstead et al. (2006), que concluíram que um pré-aquecimento em temperatura de $90^{\circ} \mathrm{C}$ por 30 a 60 segundos foi eficiente em limitar a atividade da plasmina, desta forma, o leite UHT não apresentou gelificação ou sedimentação no prazo de 6 meses após a fabricação e a maior parte das amostras de leite permaneceu estável após 8 meses a $30^{\circ} \mathrm{C}$. Por outro lado, esses autores não recomendam a faixa de temperatura de 80 a $85{ }^{\circ} \mathrm{C}$ por 30 segundos, pois verificaram que nessas condições a atividade da plasmina foi aumentada, resultando em maior gelificação e sedimentação durante $\mathrm{o}$ armazenamento.

$\mathrm{O}$ aquecimento do leite pode ser realizado de forma indireta, por meio de trocadores de calor ou de forma direta por injeção de vapor ou infusão de leite no vapor seguido de resfriamento, por expansão a vácuo. Quando o vapor é injetado no leite, sua temperatura é elevada quase instantaneamente para 140 a $150{ }^{\circ} \mathrm{C}$, o leite é mantido nessa temperatura de acordo com o tempo de tratamento UHT e, em seguida, ocorre o resfriamento instantâneo, em uma câmara de expansão em que um vácuo parcial é mantido por uma bomba. 
0 vácuo é controlado para garantir que a mesma quantidade de vapor colocada no leite seja retirada (BYLUND, 1995; WALSTRA; WOUTERS; GEURTS, 2006).

Em plantas de processamento de leite que utilizam trocadores de calor a placas, o leite inicialmente a $4{ }^{\circ} \mathrm{C}$ segue para a seção de regeneração do trocador a placas onde troca calor com o leite já processado (UHT), ocorrendo o pré-aquecimento do leite que entra e resfriamento do leite já tratado. Então, o leite préaquecido pode ser homogeneizado (18 a $25 \mathrm{Mpa}$ ). Outra opção é a homogeneização do produto após o tratamento UHT. Após essa etapa de pré-aquecimento/homogeneização, o leite é levado para a seção de aquecimento, em que a temperatura será elevada acima de $135^{\circ} \mathrm{C}$, por meio da troca de calor com água quente, sendo o produto mantido nessa temperatura no tubo de retenção pelo tempo necessário ao tratamento UHT, seguido de resfriamento e embalagem asséptica (BYLUND, 1995).

A etapa de embalagem é realizada em ambiente estéril, em embalagens pré-esterelizadas. A embalagem para leite esterilizado deve ser impermeável ao oxigênio e deve-se visar o preenchimento completo (sem espaço na cabeça). Além disso, o leite UHT é altamente suscetível a sabores desagradáveis causados pela luz, de modo que uma embalagem impermeável à luz deve ser preferida (WALSTRA; WOUTERS; GEURTS, 2006).

Com relação às suas características, o produto resultante do processo UHT apresenta coloração mais branca, decorrente do processo de homogeneização e desnaturação das proteínas do soro. Com relação ao sabor, o produto recém produzido pode apresentar sabor sulfuroso, devido a formação de grupos SH livres, formados na desnaturação das $\beta$-lactoglobulinas e, além disso, um sabor cozido pode ser percebido devido a reação de Maillard (ORDÓNEZ et al., 2005).

Embora o leite UHT tenha uma extensa vida útil, o armazenamento por longos períodos pode resultar em muitas mudanças químicas e físicas no leite, e algumas delas podem acarretar em características inaceitáveis ou, em casos graves, encerrar abruptamente o prazo de validade (FOX; MCSWEENEY, 1998; ANEMA, 2019). Algumas modificações que ocorrem no armazenamento do leite UHT podem ser percebidas pelos consumidores e referem-se a cor, sabor e textura, principalmente (ORDÓNEZ et al., 2005).

As lipases e proteases são as principais responsáveis pela deterioração do sabor ao longo do armazenamento. Essas enzimas são termorresistentes e são produzidas por microrganismos psicotróficos durante o armazenamento refrigerado do leite cru. As lipases geram sabor de ranço ou sabão, pois clivam as ligações dos triglicerídeos e liberam ácidos graxos no meio. Por outro lado, as proteases rompem as ligações da k-caseína e da $\beta$-caseína, sendo responsáveis pelo sabor amargo e gelificação do leite (ORDÓNEZ et al., 2005). Essas enzimas apresentam certa instabilidade a temperaturas mais brandas, como a faixa de 50 a $65^{\circ} \mathrm{C}$. Desta forma, uma maneira de reduzir sua atividade é aplicar um tratamento térmico como $60^{\circ} \mathrm{C}$ por 5 a 10 minutos, anterior ou posteriormente ao tratamento UHT (FOX; MCSWEENEY, 1998).

A gelificação do leite UHT é um processo irreversível, em que, ocorre a formação de uma rede proteica tridimensional, tornado o leite menos fluido. Esse processo tende a ocorrer inicialmente no fundo, mas com o tempo se estende por toda a embalagem. Um dos mecanismos envolvidos no processo de gelificação do leite está relacionado a proteases que não são inativadas durante o processamento UHT. Neste caso, essas proteases, que podem ser nativas como a plasmina ou exógenas, como aquelas produzidas por bactérias psicrotróficas, hidrolisam as proteínas do leite, levando a uma desestabilização do sistema de proteínas e gerando peptídeos. Esse processo geralmente ocorre dentro do prazo de validade do leite UHT. Outro mecanismo proposto é chamado de gelificação por idade físico-química ou não-enzimática. Nesse processo não ocorre a degradação ou hidrólise das proteínas durante o armazenamento e geralmente, acontece após o prazo de validade do leite (DATTA; DEETH, 2001; ANEMA, 2019).

Pode ainda haver a separação da gordura na superfície do leite durante o armazenamento. Essa separação está intimamente correlacionada com o teor de gordura, a temperatura de armazenamento e o tamanho do glóbulo de gordura. A taxa de separação de gordura é afetada pela eficiência da homogeneização, desta forma, quanto maior for a eficiência do processo, menor será a taxa de separação (LU et al., 2013). Além disso, na homogeneização ocorre a desnaturação das crioglobulinas (imunoglobulinas), que são responsáveis por aglutinar a gordura do leite. Uma vez desnaturadas elas perdem o potencial de aglutinação (FOX; MCSWEENEY, 1998).

Karlsson et al. (2019) realizaram um estudo com leite UHT visando identificar as alterações sensoriais que limitam o prazo de validade do produto quando armazenado em diferentes temperaturas $\left(4,20,30\right.$ e $\left.37^{\circ} \mathrm{C}\right)$. Para esse fim, parâmetros de qualidade, incluindo sabor, cor, separação de gordura, adesão de gordura, sedimentação e gelificação foram avaliados pelo período de um ano. Esses autores verificaram que a temperatura de armazenamento tem um grande impacto na estabilidade do leite UHT. 0 prazo de validade 
diminuiu significativamente com o aumento da temperatura. 0 prazo de validade do leite UHT armazenado a 4 e $20^{\circ} \mathrm{C}$ foi limitado para 34 a 36 semanas devido a formação de sedimentos, seguido de um desvio de sabor no período de 40 a 52 semanas de armazenamento. Por outro lado, o prazo de validade do leite UHT armazenado a 30 e $37^{\circ} \mathrm{C}$ foi limitado por vários parâmetros de qualidade, incluindo sabor, cor e formação de sedimentos, reduzindo sua validade para 16 a 20 semanas.

\section{REFERÊNCIAS}

[1] ABREU, L. R. Físico-química, qualidade e processamento de leite. Lavras: UFLA, 2014.

[2] ANEMA, S. G. Age Gelation, Sedimentation, and Creaming in UHT Milk: A Review. Comprehensive Reviews in Food Science and Food Safety, v. 18, n. 1, p. 140-166, 2019.

[3] BENNETT, R. J.; JOHNSTON, K. A. General Aspects of Cheese Technology. In: FOX, P.F.; McSWEENEY, P. L. H.; COGAN, T. M; GUINEE, T. P. (Ed.). Cheese: Chemistry, Physics and Microbiology. 3. ed. Academic Press, 2004.

[4] BERESFORD, T. What problems are caused by psychrotrophs? In: McSWEENEY, P.L.H (Ed.). Cheese problems solved. Cambridge: CRC press, 2007. p. 402.

[5] BRASIL (1996). Ministério da Agricultura e Abastecimento. Portaria MAPA 146, de 07/03/1996. Regulamento técnico de identidade e qualidade de queijos. Disponível em: <www.defesa.agricultura.sp.gov.br/legislacoes/portaria-mapa-146-de-07-03-1996,669.html>. Acesso em: 6 abr. 2020.

[6] BRASIL (2017). Ministério da Agricultura, Pecuária e Abastecimento. Decreto nº 9.013/2017. Dispõem sobre a inspeção industrial e sanitária de produtos de origem animal. Diário Oficial da República Federativa do Brasil, Brasília, DF, 29 març. 2017. Disponível em: <https://alimentusconsultoria.com.br/wpcontent/uploads/2017/03/DECRETO-N\%C2\%BA-9.013-DE-29-DE-MAR\%C3\%870-DE-2017-1.pdf>. Acesso em: 21 de abril de 2020.

[7] BRASIL (2018). Instrução Normativa no 76, de 26 de novembro de 2018. Aprova os Regulamentos Técnicos que fixam a identidade e as características de qualidade que devem apresentar o leite cru refrigerado, o leite pasteurizado e o leite pasteurizado tipo A. Diário Oficial da União: seção 1. Brasília, DF, 30 nov. 2018. Disponível em: < http://sistemasweb.agricultura.gov.br/sislegis/action/detalhaAto.do?method=consultarLegislacaoFederal >. Acesso em: 22 de maio de 2020.

[8] BYLUND, G. Dairy processing handbook. Tetra Pak Processing Systems ABS-221 86 Lund, Sweden, 1995.

[9] DATTA, N.; DEETH, H. C. Age gelation of UHT milk - A review. Food and Bioproducts Processing: Transactions of the Institution of of Chemical Engineers, Part C, v. 79, n. 4, p. 197-210, 2001.

[10] FOX, P. F. et al. Fundamentals of Cheese Science. Gaithersburg, Maryland: Aspen, 2000.

[11] FOX, P. F.; MCSWEENEY, P. L. H. Dairy Chemistry and Biochemistry. London: Blackie Academic \& Professional, 1998.

[12] KARLSSON, M. A. et al. Changes in stability and shelf-life of ultra-high temperature treated milk during long term storage at different temperatures. Heliyon, v. 5, n. 9, 2019.

[13] LEWIS, M. Improvements in the pasteurisation and sterilisation of milk. In: SMIT, G. (Ed.). Dairy processing Improving quality. Boca Raton: CRC press, 2003.

[14] LU, C. et al. Effects of homogenisation pressures on physicochemical changes in different layers of ultra-high temperature whole milk during storage. International Journal of Dairy Technology, v. 66, n. 3, p. 325-332, 2013.

[15] NEWSTEAD, D. F. et al. Plasmin activity in direct-steam-injection UHT-processed reconstituted milk: Effects of preheat treatment. International Dairy Journal, v. 16, n. 6, p. 573-579, 2006.

[16] ORDÓNEZ, J. A. et al. Tecnologia de Alimentos - Alimentos de Origem Animal. Porto Alegre: Artmed, 2005.

[17] SHEEHAN, J. J. What is thermisation and why is it used? In: McSWEENEY, P.L.H (Ed.). Cheese problems solved. CRC press, 2007. p. 402.

[18] STOECKEL, M. et al. Heat stability of indigenous milk plasmin and proteases from Pseudomonas: A challenge in the production of ultra-high temperature milk products. International Dairy Journal, v. 61, p. 250-261, 2016.

[19] WALSTRA, P.; WOUTERS, J. T. M.; GEURTS, T. J. Dairy Science and Technology. 2 nd ed. Netherlands: CRC Press, 2006. 


\section{Capítulo 6}

\section{Análise de vitaminas hidrossolúveis em suplementos ${ }^{1}$}

\section{Lucile Tiemi Abe-Matsumoto \\ Geni Rodrigues Sampaio \\ Deborah Helena Markowicz Bastos}

Resumo: A ingestão de vitaminas é essencial para manutenção da saúde. As vitaminas hidrossolúveis são uma classe de compostos que desempenham importantes funções em diversos processos metabólicos. Por não serem sintetizadas e nem armazenadas no organismo humano, devem ser consumidas diariamente por meio da alimentação e quando necessário, por meio de suplementos. 0 objetivo deste trabalho foi verificar a conformidade dos teores de vitaminas hidrossolúveis em 52 amostras de suplementos vitamínicos adquiridas no comércio da cidade de São Paulo. As determinações dos teores de vitaminas C, B1, B6, niacina e ácido pantotênico foram realizadas simultaneamente por cromatografia líquida de alta eficiência com detector de arranjo de diodos (CLAE-DAD). De acordo com a Resolução RDC no 360/2003 da ANVISA/MS (Agência Nacional de Vigilância Sanitária do Ministério da Saúde), é permitida uma tolerância de 20\% dos valores declarados nos rótulos. Considerando essa tolerância, a vitamina $\mathrm{C}$ e o ácido pantotênico foram as vitaminas que apresentaram os maiores índices de não conformidades, com $37 \%$ e $21 \%$ respectivamente, das amostras com concentrações abaixo dos valores declarados. Há necessidade de maior controle e vigilância destes produtos para que a população tenha acesso a suplementos multivitamínicos seguros e com informações confiáveis sobre seu conteúdo.

Palavras-Chave: suplemento alimentar, vitaminas hidrossolúveis, informação nutricional, CLAE. 


\section{INTRODUÇÃO}

Vitaminas são micronutrientes essenciais para a manutenção da saúde, assim, a ingestão insuficiente de qualquer uma delas pode levar a problemas de saúde e desenvolvimento de doenças. Uma dieta equilibrada deve fornecer as quantidades necessárias de vitaminas ao organismo (FAO, 2001). No entanto, devido a perdas durante o processamento e armazenamento, e também por certos grupos populacionais necessitarem de maior ingestão de vitaminas, vários suplementos à base destes micronutrientes são comercializados no mercado, sendo amplamente consumidos pela população. Em decorrência das mudanças no estilo de vida, onde houve aumento no consumo de alimentos processados e redução no consumo de alimentos in natura, a ingestão de vitaminas por meio dos suplementos tornou-se uma prática comum. 0 aumento da expectativa de vida e a preocupação com uma vida saudável também passaram a ser prioridades para uma parcela crescente da população, que está disposta a investir tempo e recursos com a finalidade de viver mais e melhor (ABE-MATSUMOTO, 2015).

Em 2010, com a publicação da Resolução RDC no 27/2010 da Agência Nacional de Vigilância Sanitária do Ministério da Saúde (ANVISA/MS), os suplementos vitamínicos e/ou de minerais passaram a ser isentos de registro no Ministério da Saúde, facilitando a comercialização destes produtos e levando consequentemente, a um aumento visível de novos produtos no mercado (ANVISA, 2010). Em julho de 2018 foi publicado o novo marco regulatório de suplementos alimentares, com prazo de 60 meses para as empresas se adequarem às novas normas. Com a nova regulamentação, os produtos à base de vitaminas os quais eram denominados de suplementos vitamínicos passaram a ser denominados de suplemento alimentar e continuam isentos de registro sanitário. A Portaria no 32/1998 da Secretaria de Vigilância em Saúde do Ministério da Saúde (SVS/MS) que estabelecia o Regulamento Técnico para suplementos vitamínicos e ou minerais foi revogada com a publicação das novas normas (BRASIL, 1998; ANVISA, 2018).

As vitaminas hidrossolúveis são conhecidas por seu papel especial no metabolismo energético, bem como na manutenção da saúde dos músculos, pele, olhos, cabelo e fígado. Agem como precursores de coenzima e cofatores enzimáticos em diferentes reações no organismo, como por exemplo, o metabolismo de lipídios, carboidratos e proteínas. Com excessão da vitamina B12, não são armazenadas no organismo, portanto, devem ser ingeridas diariamente para garantir a manutenção das funções metabólicas e da saúde (FAO, 2001). A dieta humana nem sempre contém a quantidade ideal de nutrientes, tornando-se necessária a suplementação. Para essa finalidade, o mercado atualmente oferece uma grande variedade de suplementos à base de vitaminas, porém, é importante verificar se os teores destas vitaminas estão de acordo com os valores declarados na informação nutricional da rotulagem. Assim, o objetivo deste trabalho foi determinar os teores de vitaminas hidrossolúveis (C, B1, B6, niacina e ácido pantotênico) em suplementos vitamínicos comercializados na cidade de São Paulo e confrontar os valores analisados com os declarados na rotulagem.

\section{MATERIAL E MÉTODOS}

\subsection{AMOSTRAS}

Foram avaliadas 52 amostras de diferentes marcas de suplementos vitamínicos apresentadas em diferentes formas: comprimidos, drágeas, cápsulas gelatinosas duras e moles (Softgel), suspensões e soluções. As amostras foram adquiridas no comércio da cidade de São Paulo, Brasil, e foram avaliadas quanto aos teores das vitaminas C, B1, B6, niacina e ácido pantotênico. Para obter uma amostra representativa dos produtos comercializados, foram utilizados os seguintes critérios de seleção: Matrizes e composições diferentes, amostras nacionais e importadas, suplementos de empresas multinacionais e de pequenas empresas nacionais.

\subsection{PADRÕES, REAGENTES, MATERIAL DE REFERÊNCIA CERTIFICADO E AMOSTRAS}

Os padrões de cloridrato de tiamina (vitamina B1), cloridrato de piridoxina (vitamina B6), nicotinamida, ácido nicotínico e ácido pantotênico foram adquiridos da Sigma-Aldrich (St Louis, EUA); e o ácido ascórbico (vitamina C) da Supelco (Bellefonte, EUA). Foram utilizados os seguintes solventes grau cromatográfico: metanol da Carlo Erba e clorofórmio da J. T. Baker (Bakerbond, EUA). 0 HCl (ácido clorídrico) e o ácido orto fosfórico foram obtidos da Merck (Darmstadt, Alemanha), e o fosfato de sódio monobásico, da Calbiochem (San Diego, EUA). 


\subsection{EQUIPAMENTOS}

A pulverização das matrizes drágeas e comprimidos foi realizada em moinho vibratório, modelo MM400, marca Retsch Technology (Haan, Alemanha). Para os procedimentos de análise, utilizou-se balança analítica modelo XS205, marca Mettler Toledo (Schwerzenbach, Suíça); banho ultrassônico modelo Ultracleaner 1400, marca Unique (São Paulo, Brasil); centrífuga modelo 3-18K, marca Sigma (Osterode, Alemanha); concentrador de amostras modelo Centrivap, marca Labconco (Kansas City, EUA). A leitura das absorbâncias dos padrões de vitaminas e de $\beta$-caroteno foi realizada em espectrofotômetro UV/Visível modelo UV-X1650PC, marca Shimadzu (Kyoto, Japão) e o ajuste de pH da solução tampão foi realizado em pHmetro digital, modelo PG1800, marca Gehaka (São Paulo, Brasil). A água foi purificada pelo sistema MilliQ, da Millipore (Bedford, EUA).

As análises cromatográficas foram realizadas em cromatógrafo líquido de alta eficiência, modelo LC-20AT, com injetor automático SIL-20AC, controlador CBM-20A, forno de coluna CTO-20A e detector de arranjo de diodos PDA-20A, marca Shimadzu (Kyoto, Japão). Foi utilizada uma coluna cromatográfica de fase reversa C18 Shim-Pack VP-ODS-2 (150 mm x 4,6 mm, partículas de 5 um), marca Shimadzu (Kyoto, Japão).

\subsection{DETERMINAÇÃO DE VITAMINAS HIDROSSOLÚVEIS}

As análises foram realizadas de acordo com a metodologia validada por Abe-Matsumoto (2016). Utilizou-se cerca de $350 \mathrm{mg}$ da amostra pulverizada e a extração das vitaminas foi realizada com solução tampão fosfato de sódio $0,05 \mathrm{M}(\mathrm{pH} 3,0)$. Para análise em matriz oleosa, pesou-se uma quantidade de amostra entre $150 \mathrm{e}$ $400 \mathrm{mg}$ e a extração foi realizada com clorofórmio e tampão fosfato. Em matriz líquida, pipetou-se um volume entre 1 e $3 \mathrm{~mL}$, seguindo o mesmo procedimento utilizado para as matrizes pulverizadas.

A fase móvel foi constituída de metanol (A) e tampão fosfato de sódio 0,05 M (B), em modo de gradiente linear, iniciando com $98 \%$ de A, passando para $40 \%$ de A em 9 min, retornando para a condição inicial em $15 \mathrm{~min}$, e mantendo-se nesta proporção até $25 \mathrm{mim}$ para equilíbrio da fase móvel, com fluxo de $0,8 \mathrm{~mL} / \mathrm{min}$. 0 volume de injeção foi de $10 \mu \mathrm{L}$ e as temperaturas no injetor automático e no forno de coluna foram mantidas a $15^{\circ} \mathrm{C} \mathrm{e} 26^{\circ} \mathrm{C}$, respectivamente. 0 ácido pantotênico foi detectado a $209 \mathrm{~nm}$, a tiamina, vitamina C, nicotinamida e ácido nicotínico a $254 \mathrm{~nm}$ e a piridoxina a $283 \mathrm{~nm}$.

\section{RESULTADOS E DISCUSSÃO}

Do total de amostras analisadas, $25 \%$ apresentaram todas as vitaminas de acordo com os valores declarados na informação nutricional da rotulagem, considerando a tolerância de $20 \%$ permitida pela legislação (ANVISA, 2003). Outros 33\% apresentaram uma ou mais vitaminas acima do valor declarado, enquanto $54 \%$ das amostras apresentaram uma ou mais vitaminas abaixo do valor declarado, destacando que algumas amostras apresentaram teor de uma vitamina abaixo e de outra vitamina acima dos valores declarados no rótulo.

A Figura 1 representa as porcentagens de conformidades e não conformidades dos teores de vitaminas hidrossolúveis analisadas em relação aos valores declarados no rótulo. Dentre as cinco vitaminas avaliadas, a vitamina $\mathrm{C}$ foi o composto com maior porcentagem de inadequação em relação aos teores abaixo dos valores declarados (37\%). Por outro lado, a vitamina B1 apresentou a menor porcentagem (10\%) de inadequação em relação aos teores abaixo do declarado, porém, observou-se a maior porcentagem de sobredosagem (23\%), ou seja, teor analisado acima de $20 \%$ do valor declarado. Na legislação anterior, o limite máximo de vitaminas em um suplemento correspondia a $100 \%$ da IDR (Ingestão Diária Recomendada) e a sobredosagem de micronutrientes era permitida para garantir os seus teores até o prazo final de validade, desde que justificada tecnologicamente, já que as vitaminas podem sofrer degradação (BRASIL, 1998). Na nova legislação, o limite máximo de vitaminas em um suplemento alimentar foi estabelecido com base na UL (Limite superior tolerável), e portanto, a sobredosagem é permitida, desde que o produto tal como exposto à venda não ultrapasse as quantidades máximas estabelecidas na Instrução Normativa (IN) n 28/2018 da Anvisa. 
Figura 1 - Porcentagens de conformidades e inconformidades dos teores de vitaminas $\mathrm{C}, \mathrm{B}_{1}$, niacina, $\mathrm{B}_{6} \mathrm{e}$ ácido pantotênico em suplementos vitamínicos.

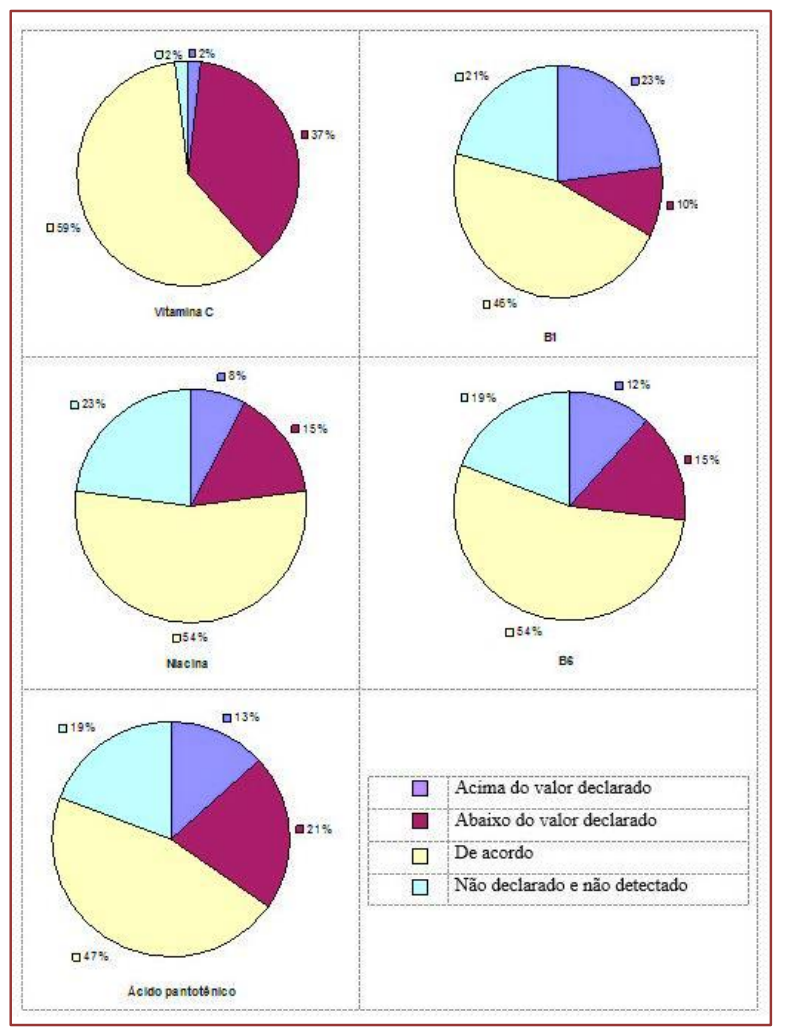

Tabela 1. Conteúdo de vitamina C (mg por porção), B 1 (mg por porção), B 6 (mg por porção), niacina (mg por porção) e ácido pantotênico (mg por porção) em amostras de suplementos vitamínicos na forma de comprimidos, drágeas e cápsulas gelatinosas duras, em comparação aos valores declarados na informação nutricional do rótulo

\begin{tabular}{|c|c|c|c|c|c|c|c|c|c|c|c|c|c|c|c|}
\hline \multirow[b]{2}{*}{ Amostras } & \multicolumn{3}{|c|}{ Vitamina C } & \multicolumn{3}{|c|}{ Vitamina $B_{1}$} & \multicolumn{3}{|c|}{ Vitamina $B_{6}$} & \multicolumn{3}{|c|}{ Niacina } & \multicolumn{3}{|c|}{ Acido pantotênico } \\
\hline & $\mathrm{VD}^{*}$ & $\mathrm{VA}^{* 8}$ & $\%^{888}$ & $\mathrm{VD}^{*}$ & $V^{* *}$ & $\%^{* 88}$ & $\mathrm{VD}^{*}$ & $V^{* 8}$ & $\%^{888}$ & $\mathrm{VD}^{*}$ & $V^{8 *}$ & $\%^{8 * 8}$ & $\mathrm{VD}^{*}$ & $\mathrm{VA}^{8 *}$ & $\%^{8 * 8}$ \\
\hline 1 & 45 & $41,3 \pm 0,5$ & $-8,20$ & 1,0 & $1,1=0,05$ & 10,0 & 1 & $1,2 \pm 0,02$ & 20,0 & 10 & $10,9 \pm 0,2$ & 9,00 & 2,5 & $2,9 \pm 0,01$ & 16,0 \\
\hline 2 & 45 & $49,2 \pm 0,8$ & 9,40 & 1,2 & $1,8 \pm 0,06$ & 50,0 & 1,3 & $1,7 \pm 0,01$ & 28,5 & 16 & $15,7 \pm 0,3$ & $-1,90$ & 5 & $6,0 \pm 0,1$ & 20,0 \\
\hline 3 & 45 & $30,9 \pm 1,1$ & $-31,4$ & 1,2 & $1,1=0,01$ & $-8,30$ & 1,3 & $0,97 \pm 0,01$ & $-25,4$ & 16 & $15,1 \pm 0,1$ & $-5,60$ & 5 & $5,0 \pm 0,01$ & 0,0 \\
\hline 4 & 45 & $37,8 \pm 0,7$ & $-15,9$ & 1,2 & $1,3 \pm 0,06$ & 8,30 & 1,3 & $1,6 \pm 0,03$ & 19,2 & 16 & $17,2 \pm 0,1$ & 7,50 & 5 & $6,0 \pm 0,2$ & 20,0 \\
\hline 5 & 45 & $30,7 \pm 0,2$ & $-31,7$ & 1,2 & $0,6 \pm 0,01$ & $-50,0$ & 1,3 & $0,96 \pm 0,02$ & $-26,2$ & 16 & $13,5 \pm 0,1$ & $-15,6$ & 5 & $3,5 \pm 0,1$ & $-30,0$ \\
\hline 6 & 45 & $36,8=0,5$ & $-18,3$ & 1,2 & $1,7 \pm 0,01$ & 41,7 & 1,3 & $1,2 \pm 0,02$ & $-10,0$ & 16 & $15,4 \pm 0,3$ & $-3,80$ & 5 & $6,8 \pm 0,2$ & 36,0 \\
\hline 7 & 45 & $39,9 \pm 0,7$ & $-11,2$ & 1,2 & $1,4 \pm 0,01$ & 16,7 & 0,9 & $1,1 \pm 0,03$ & 20,0 & 13 & $14,3 \pm 0,01$ & 10,0 & 5 & $6,2 \pm 0,01$ & 24,0 \\
\hline 8 & 45 & $41,0=0,5$ & $-9,00$ & 1,2 & $1,3 \pm 0,01$ & 8,3 & 1,3 & $1,3 \pm 0,01$ & $-3,10$ & nd & nd & - & 5 & $5,1 \pm 0,01$ & 2,00 \\
\hline 9 & 45 & $34,8 \pm 1,7$ & $-22,6$ & 1,2 & $1,3 \pm 0,01$ & 8,3 & 1,3 & $1,30 \pm 0,04$ & 0,00 & 16 & $13,5 \pm 0,06$ & $-15,6$ & 5 & $4,0 \pm 0,1$ & $-20,0$ \\
\hline 10 & 45 & $51,1 \pm 1,6$ & 13,7 & 1,2 & $1,4 \pm 0,01$ & 16,7 & 1,3 & $1,3 \pm 0,05$ & 0,0 & 5 & $5,0 \pm 0,02$ & 0,00 & 5 & $4,1 \neq 0,05$ & $-18,0$ \\
\hline 11 & 45 & $33,6=0,3$ & $-25,3$ & 1,2 & $1,4 \pm 0,01$ & 16,7 & 1,3 & $1,3 \pm 0,03$ & 0,0 & 16 & $14,0=0,05$ & $-12,5$ & 5 & $5,1 \neq 0,01$ & 2,00 \\
\hline 12 & 45 & $44,8 \pm 1,2$ & $-0,50$ & 1,2 & $1,2=0,01$ & 0,0 & 1,3 & $1,2 \pm 0,02$ & $-9,20$ & 16 & $16,2 \pm 0,1$ & 1,30 & 5 & $4,7 \pm 0,1$ & $-6,00$ \\
\hline 13 & 45 & $40,9=1,3$ & $-9,20$ & 1,2 & $1,5 \pm 0,08$ & 25,0 & 1,3 & $1,4 \pm 0,08$ & 3,80 & 16 & $14,7 \pm 0,3$ & $-8,10$ & 5 & $6,4=0,3$ & 28,0 \\
\hline 14 & 45 & $37,3=0,2$ & $-17,0$ & 1,2 & $1,4 \pm 0,01$ & 16,7 & 1,3 & $1,4=0,01$ & 7,70 & 16 & $13,7 \pm 0,2$ & $-14,4$ & 5 & $5,5 \pm 0,01$ & 10,0 \\
\hline 15 & 22,5 & $17,2 \pm 0,3$ & $-23,5$ & 0,6 & $0,8 \pm 0,01$ & 33,3 & 0,65 & $0,7 \pm 0,01$ & 7,70 & 8 & $8,1 \neq 0,1$ & 1,30 & 2,5 & $2,7 \pm 0,001$ & 8,00 \\
\hline 16 & 45 & $41,9=1,5$ & $-6,90$ & 1,2 & $1,3 \pm 0,01$ & 8,3 & 1,3 & $1,4=0,05$ & 6,90 & 16 & $15,3 \pm 0,4$ & $-4,40$ & 5 & $5,6 \pm 0,2$ & 12,0 \\
\hline 17 & 45 & $35,9=0,5$ & $-20,2$ & 1,2 & $1,1=0,05$ & $-8,3$ & 1,3 & $1,8 \pm 0,07$ & 40,0 & 16 & $13,3=0,07$ & $-16,9$ & 5 & $4,8=0,2$ & $-4,00$ \\
\hline 18 & 45 & $39,9=0,8$ & $-11,2$ & 1,2 & $1,6 \pm 0,07$ & 33,3 & 1,3 & $1,5 \pm 0,001$ & 10,8 & 16 & $15,9=0,1$ & $-0,60$ & 5 & $6,1=0,1$ & 22,0 \\
\hline 19 & 45 & $38,0 \pm 1,3$ & $-15,5$ & 1,1 & $1,1=0,05$ & 0,0 & 1,3 & $1,1=0,01$ & $-13,8$ & 16 & $14,7 \pm 0,2$ & $-8,10$ & 5 & ND & -100 \\
\hline 20 & 45 & $44,2=0,8$ & $-1,70$ & nd & $\mathrm{ND}$ & - & nd & ND & - & nd & ND & - & nd & ND & - \\
\hline 21 & 45 & $22,4 \pm 1,3$ & $-50,2$ & nd & ND & - & nd & ND & - & nd & ND & - & nd & ND & - \\
\hline 22 & 45 & $46,4=0,6$ & 3,10 & nd & ND & - & nd & ND & - & nd & ND & - & nd & ND & - \\
\hline 23 & 45 & $33,7 \pm 0,3$ & $-25,0$ & 1,1 & $0,8 \pm 0,001$ & $-27,3$ & 0,5 & $0,43 \pm 0,02$ & $-14,0$ & 13 & $11,8 \pm 0,1$ & $-9,20$ & 5 & $1,7 \pm 0,01$ & $-66,0$ \\
\hline 24 & 45 & $40,5=0,5$ & $-9,90$ & 1,1 & $0,8 \pm 0,01$ & $-27,3$ & 0,5 & $0,51=0,02$ & 2,00 & 13 & $12,2 \pm 0,1$ & $-6,20$ & 5 & $3,8 \pm 0,02$ & $-24,0$ \\
\hline 25 & 45 & $43,2=0,2$ & $-3,90$ & 1,1 & $1,2 \pm 0,001$ & 9,1 & 0,5 & $0,53 \pm 0,01$ & 6,00 & 13 & $12,8 \pm 0,2$ & $-1,50$ & 5 & $1,9 \pm 0,001$ & $-62,0$ \\
\hline 26 & 45 & $40,6 \pm 0,2$ & $-9,80$ & 1,1 & $0,8 \pm 0,001$ & $-27,3$ & 0,5 & $0,48 \pm 0,01$ & $-4,00$ & 13 & $12,2 \pm 0,1$ & $-6,20$ & 5 & $3,5 \pm 0,02$ & $-30,0$ \\
\hline 27 & 45 & $41,7 \pm 0,5$ & $-7,40$ & 1,2 & $1,3 \pm 0,01$ & 8,3 & 1,3 & $1,3 \pm 0,06$ & 0,0 & 16 & $16,8 \pm 1,1$ & 5,00 & 5 & $5,5 \pm 0,03$ & 10,0 \\
\hline 28 & 45 & $25,2 \pm 0,8$ & $-44,0$ & 1,2 & $1,0 \pm 0,001$ & $-16,7$ & 1,3 & $0,81=0,05$ & $-37,7$ & 16 & $10,0 \pm 0,4$ & $-37,5$ & 5 & $3,5 \pm 0,08$ & $-30,0$ \\
\hline 29 & 45 & $35,0 \pm 1,0$ & $-22,2$ & 1,2 & $1,3 \pm 0,001$ & 8,3 & 1,3 & 1,3 & 0,0 & 16 & $17,3 \pm 0,3$ & 8,10 & 5 & $5,7 \pm 0,001$ & 14,0 \\
\hline 30 & 45 & $39,3 \pm 1,9$ & $-12,7$ & nd & ND & - & nd & ND & - & nd & $\mathrm{ND}$ & - & nd & $\mathrm{ND}$ & - \\
\hline 31 & 45 & $30,4=0,1$ & $-32,5$ & nd & ND & - & nd & ND & - & nd & ND & - & nd & ND & - \\
\hline
\end{tabular}

Amostras 1 a 22: comprimidos; Amostras 23 a 26: drágeas; Amostras 27 a 30: cápsulas gelatinosas duras;

*VD: Valor declarado; **VA: Valor analisado (média \pm desvio padrão; n=3); CV < 10 \%);

***\%: Conformidade entre os valores analisados e declarados; nd: não declarado; ND: não detectado. 
Tabela 2. Conteúdo de vitamina C (mg por porção), B 1 (mg por porção), B 6 (mg por porção), niacina (mg por porção) e ácido pantotênico (mg por porção) em amostras de suplementos vitamínicos na forma de cápsulas gelatinosas moles (Softgel), suspensões e soluções em comparação aos valores declarados na informação nutricional do rótulo

\begin{tabular}{|c|c|c|c|c|c|c|c|c|c|c|c|c|c|c|c|}
\hline \multirow[b]{2}{*}{ Amostras } & \multicolumn{3}{|c|}{ Vitamina C } & \multicolumn{3}{|c|}{ Vitamina $\mathrm{B}_{1}$} & \multicolumn{3}{|c|}{$V_{\text {itamina }} B_{6}$} & \multicolumn{3}{|c|}{ Niacina } & \multicolumn{3}{|c|}{ Acido pantotênico } \\
\hline & VD* & $\mathrm{VA}^{* *}$ & $\% * * *$ & $\mathrm{VD}^{*}$ & $\mathrm{VA}^{* *}$ & $\% * * *$ & $\underset{*}{\mathrm{VD}}$ & $\mathrm{VA}^{* *}$ & $\% * * *$ & $\begin{array}{c}\text { VD } \\
*\end{array}$ & $\mathrm{VA}^{* *}$ & $\% * * *$ & $\mathrm{VD}^{*}$ & $V^{*} * *$ & $\% * * *$ \\
\hline 32 & 45 & $47,4 \pm 1,5$ & 5,4 & 1,2 & $1,2 \pm 0,05$ & 0,0 & 1,3 & $0,99 \pm 0,02$ & $-23,8$ & 16 & $3,8 \pm 0,001$ & $-76,3$ & 5 & $4,2 \pm 0,2$ & $-16,0$ \\
\hline 33 & 45 & $49,2 \pm 1,1$ & 9,3 & 1,2 & $1,6 \pm 0,06$ & 33,3 & 1,3 & $0,79 \pm 0,02$ & $-39,2$ & 16 & $12,1=0,2$ & $-24,4$ & 5 & $6,4 \pm 0,1$ & 28,0 \\
\hline 34 & 45 & $12,1 \pm 1,6$ & $-73,0$ & 1,2 & $0,5 \pm 0,001$ & $-58,2$ & 1,3 & $0,96 \pm 0,03$ & $-26,2$ & 16 & $10,0 \pm 0,2$ & $-37,5$ & 5 & $1,3 \pm 0,3$ & $-74,0$ \\
\hline 35 & 45 & $27,6 \pm 0,8$ & $-38,6$ & 1,2 & $1,3 \pm 0,001$ & 8,3 & 1,3 & $0,66 \pm 0,02$ & $-49,2$ & 16 & $7,8 \pm 0,2$ & $-51,3$ & 4,6 & $5,5 \pm 0,2$ & 19,6 \\
\hline 36 & 45 & $34,4 \pm 0,5$ & $-23,5$ & nd & ND & - & nd & ND & - & nd & ND & - & nd & ND & - \\
\hline 37 & 45 & $43,2 \pm 1,4$ & $-4,0$ & nd & ND & - & 1,3 & $1,5 \pm 0,04$ & 13,1 & 16 & $20,9=0,9$ & 30,6 & 5 & $5,4=0,1$ & 8,0 \\
\hline 38 & 45 & $32,7 \pm 0,4$ & $-27,4$ & 1,2 & $1,6 \pm 0,001$ & 33,3 & 1,3 & $1,6 \pm 0,07$ & 26,9 & 16 & $16,7 \pm 0,2$ & 4,4 & 5 & nd & $-100,0$ \\
\hline 39 & 45 & $35,1 \pm 1,9$ & $-21,9$ & 1,2 & $1,3 \pm 0,02$ & 8,3 & 1,3 & $1,6 \pm 0,01$ & 23,8 & 16 & $21,2 \pm 0,4$ & 32,5 & 5 & $6,8 \pm 0,2$ & 36,0 \\
\hline 40 & 55 & $53,6 \pm 0,6$ & $-2,5$ & 1,4 & $2,0 \pm 0,01$ & 42,9 & 1,9 & $2,2 \pm 0,03$ & 17,9 & nd & ND & - & nd & ND & \\
\hline 41 & 11 & $4,79 \pm 0,6$ & $-56,5$ & 0,3 & $0,4 \pm 0,001$ & 33,3 & 0,3 & $0,31=0,05$ & 3,30 & 3,5 & $2,6 \pm 0,2$ & $-25,7$ & 1,3 & $0,7 \pm 0,05$ & $-46,2$ \\
\hline 42 & 45 & $44,3 \pm 0,7$ & $-1,6$ & 1,1 & $1,5 \pm 0,001$ & 36,4 & 1,3 & $0,63 \pm 0,03$ & $-51,5$ & 13 & $15,9=0,3$ & 22,3 & 5 & $5,5 \pm 0,06$ & 10,0 \\
\hline 43 & nd & ND & - & nd & ND & - & nd & ND & - & nd & ND & - & 5 & $4,9 \pm 0,02$ & $-2,0$ \\
\hline 44 & 45 & $57,0 \pm 1,2$ & 26,6 & 1,2 & $1,6 \pm 0,06$ & 33,3 & 1,3 & $1,3 \pm 0,07$ & 0,0 & 16 & $8,5 \pm 0,3$ & $-46,9$ & 5 & $6,6 \pm 0,08$ & 32,0 \\
\hline 45 & 25 & $29,4 \pm 0,4$ & 17,8 & nd & ND & - & nd & ND & - & nd & ND & - & nd & ND & - \\
\hline 46 & 30 & $34,5 \pm 0,8$ & 14,9 & nd & ND & - & nd & ND & - & nd & ND & - & nd & ND & - \\
\hline 47 & 30 & $34,0 \pm 0,5$ & 13,5 & nd & ND & - & nd & ND & . & nd & ND & - & nd & ND & - \\
\hline 48 & 30 & $22,2=0,1$ & $-26,0$ & 0,6 & $0,5 \pm 0,001$ & $-16,7$ & 0,5 & $0,42 \pm 0,01$ & $-16,0$ & 8 & $7,2 \pm 0,1$ & $-10,0$ & 3 & $3,6 \pm 0,06$ & 20,0 \\
\hline 49 & 4,5 & $3,6 \pm 0,001$ & $-19,8$ & 0,12 & $0,1=0,001$ & $-16,7$ & 0,1 & $0,12 \pm 0,01$ & 20,0 & 1,6 & $1,6 \pm 0,001$ & 0,0 & 0,5 & $0,7 \pm 0,001$ & 40,0 \\
\hline 50 & 10 & $9,7 \pm 0,2$ & $-3,0$ & 0,12 & $0,2 \pm 0,001$ & 66,7 & 0,1 & $0,15 \pm 0,01$ & 50,0 & 1,4 & $1,7 \pm 0,001$ & 21,4 & 0,6 & $0,1=0,001$ & $-83,3$ \\
\hline 51 & 30 & $20,5 \pm 0,1$ & $-31,6$ & 0,6 & $0,6 \pm 0,001$ & 0,0 & 0,6 & $0,52 \pm 0,01$ & $-13,3$ & 8,0 & $9,0 \pm 0,001$ & 12,5 & 3 & $3,2 \pm 0,03$ & 6,7 \\
\hline 52 & 36 & $1,2 \pm 0,001$ & $-96,7$ & 0,8 & $0,7 \pm 0,01$ & $-12,5$ & 1,2 & $1,9=0,05$ & 57,5 & 11 & $2,6 \pm 0,1$ & $-76,4$ & 3,6 & $4,0 \pm 0,04$ & 11,1 \\
\hline
\end{tabular}

Amostras 32 a 44: cápsulas gelatinosas moles (Softgel); Amostras 45 a 50: suspensões; Amostras 51 e 52: soluções;

*VD: Valor declarado; **VA: Valor analisado (média \pm desvio padrão; $\mathrm{n}=3$; CV < 10 \%);

***\%: Conformidade entre os valores analisados e declarados; nd: não declarado; ND: não detectado.

Dentre as vitaminas hidrossolúveis, a vitamina $\mathrm{C}$ é conhecida por apresentar menor estabilidade, sendo a temperatura e o pH descritos por diversos autores como os principais fatores que influenciam a sua degradação (CARITÁ et al., 2020). Assim, esperava-se encontrar alta porcentagem de sobredosagem de vitamina $\mathrm{C}$, porém, apenas $2 \%$ das amostras apresentaram teores acima do valor declarado.

As tabelas 1 e 2 apresentam os resultados das análises das vitaminas C, B1, B6, niacina e ácido pantotênico em diferentes matrizes de suplementos vitamínicos, comparando os valores analisados com os declarados no rótulo. As maiores inconformidades foram observadas nas amostras 19 (comprimido) e 38 (Softgel), os quais declaravam na informação nutricional, uma concentração de $5 \mathrm{mg}$ de ácido pantotênico na porção. Nestas duas amostras, porém, o ácido pantotênico não foi detectado. A amostra 52 (solução) também apresentou uma grande divergência entre o valor analisado e declarado, revelando um teor 76\% abaixo do declarado. Outras não conformidades em destaque foram observadas nas amostras 34 (Softgel), 21 (comprimido) e 35 (Softgel), com teores 58\%, 50\% e 49\%, respectivamente, abaixo dos valores declarados. Por outro lado, a amostra 50 (suspensão) apresentou uma concentração 67\% acima do valor declarado na informação nutricional para a vitamina B1. Apesar deste valor estar acima do declarado, não representa risco à saúde, pois não atinge a concentração correspondente a $100 \%$ da IDR na faixa etária para a qual o produto era indicado. Provavelmente, esta sobredosagem foi realizada para garantir os teores da vitamina até o prazo final de validade. Observou-se alta prevalência de inconformidades nos teores de vitaminas analisadas em relação aos valores declarados no rótulo. A suplementação da dieta com suplementos vitamínicos é importante para reduzir a prevalência de inadequação destes micronutrientes, porém, os valores declarados nos rótulos devem ser compatíveis com as reais concentrações presentes nos produtos.

\section{CONCLUSÕES}

Os resultados demonstraram grande variabilidade entre as quantidades de vitaminas declaradas nos rótulos dos suplementos com as determinadas analiticamente. Foi encontrada uma porcentagem maior de não conformidades para a vitamina $C$, enquanto a niacina teve as maiores porcentagens de conformidade em relação ao conteúdo declarado no rótulo. A alta porcentagem de não conformidades observada neste estudo demostra falta de controle e a necessidade urgente de ações de fiscalização. Tais medidas serão imprescindíveis para garantir o direito do consumidor de adquirir produtos seguros contendo informação mais confiáveis. 


\section{AGRADECIMENTOS}

À Fundação de Amparo à Pesquisa do Estado de São Paulo (FAPESP) pelo auxílio financeiro (Processo no 2013/23006-4).

\section{REFERÊNCIAS BIBLIOGRÁFICAS}

[1] FAO/OMS. Human Vitamin and Mineral Requirements. In: Report 7th Joint FAO/OMS Expert Consultation. Bangkok, Thailand, 2001.286p.

[2] Abe-Matsumoto, L.T., Sampaio, G.R., Bastos, D.H.M. (2015). Suplementos vitamínicos e/ou minerais: regulamentação, consumo e implicações à saúde. Cadernos de Saúde Pública, 31(7):1371-80.

[3] ANVISA - Agência Nacional de Vigilância Sanitária. Resolução RDC no 27, de 6 de agosto de 2010. Dispõe sobre as categorias de alimentos e embalagens isentos e com obrigatoriedade de registro sanitário. Diário Oficial da União, Brasília

[4] ANVISA - Agência Nacional de Vigilância Sanitária. Resolução RDC no 243, de 26 de julho de 2018. Dispõe sobre os requisitos sanitários dos suplementos alimentares. Diário oficial da União, Brasília.

[5] Abe-Matsumoto, L. T., Sampaio, G. R., Bastos, D. H. M. (2016). Validação e aplicação de métodos cromatográficos para determinação de vitaminas em suplementos. Revista do Instituto Adolfo Lutz, 75, 1-14. Disponível em: http://revistas.bvs-vet.org.br/rialutz/article/view/33889.

[6] ANVISA - Agência Nacional de Vigilância Sanitária. Resolução RDC no 360, de 23 de dezembro de 2003. Aprova o Regulamento Técnico sobre Rotulagem Nutricional de Alimentos Embalados, tornando obrigatória a rotulagem nutricional. Diário Oficial União. Brasília.

[7] BRASIL. Ministério da Saúde. Portaria n 32, de 13 de Janeiro de 1998. Regulamento Técnico para Fixação de Identidade e Qualidade de Suplementos Vitamínicos e ou de Minerais. Diário Oficial da União, Brasília.

[8] ANVISA - Agência Nacional de Vigilância Sanitária. Instrução Normativa no e 28, de 26 de julho de 2018. Estabelece as listas de constituintes, de limites de uso, de alegações e de rotulagem complementar dos suplementos alimentares. Diário Oficial da União, Brasília.

[9] Caritá, A.C., Fonseca-Santos, B., Shultz, J.D., Michniak-Kohn, B., Chorilli, M., Leonardi, G.R. (2020). Vitamin C: One compound, several uses. Advances for delivery, efficiency and stability. Nanomedicine, 24:102-117. 


\section{Capítulo 7}

Elaboração de bolinhos fritos com farinha de arroz (Oryza sativa L.)

\section{Arianne Dantas Viana}

Gleyce Swellen de Azevedo Moura

Maria José de Figueiredo

Mikassia Rosa Faustino

Karolayne da Silva Luz

Felipe Moreira da Silva

Anderson Ferreira Vilela

Erick Gabriel da Silva

Resumo: Este trabalho teve como objetivo elaborar e analisar algumas caraterísticas físico-químicas de bolinhos fritos de farinha de arroz (Oryza sativa L.), como uma alternativa de alimento sem glúten. Foi realizada a elaboração de duas formulações: uma com farinha de arroz parboilizado (F1) e outra com farinha de arroz integral (F2). Os bolinhos prontos foram submetidos as análises físico-químicas: teor de água, atividade de água, teor de lipídeos e determinação de cor $-\mathrm{L}^{*}, \mathrm{a}^{*}, \mathrm{~b}^{*}$. 0 percentual do teor de água para F1 foi de 50,47\% e para F2 foi 52,18\%, para o teor de lipídeos - F1 foi de 7,11\% e F2 foi de 11,50\%, apresentaram diferença significativa. Quanto aos parâmetros de cor, a formulação F1 apresentou-se mais clara $L^{*}$, avermelhada e amarelada $\left(a^{*}\right.$ e $\left.b^{*}\right)$ respectivamente. Verificou-se que a composição dos tipos de arroz utilizados pode ter influenciado nos resultados avaliados.

Palavras-Chave: arroz integral, alimento sem glúten, qualidade nutricional, celíacos 


\section{INTRODUÇÃO}

A farinha de arroz é obtida pela moagem do arroz, seja em grãos inteiros ou partidos, seguido pela classificação granulométrica e embalagem (BASSINELLO et al., 2017). Considerando que o arroz é um cereal facilmente encontrado no comérico e amplamente utilizado na alimentação humana, apresenta boas características nutricionais e sensoriais, a sua farinha também pode ser utilizada para substituir parcialmente ou totalmente qualquer tipo de farinha de cereais, tornando-se uma excelente opção para a produção de produtos alimentícios isentos de glúten, destinados aos celíacos (ACELBRA, 2019; OLIVEIRA et al., 2018).

A maior dificuldade na alimentação dos celíacos está no acesso aos produtos elaborados com substitutos da farinha de trigo e que ofereçam características sensoriais favoráveis e agradáveis ao consumidor. Os produtos sem glúten disponíveis no mercado ainda não são produzidos em larga escala, tem alto custo e se tornam inacessíveis às classes sociais menos favorecidas. Porém o mercado que atende os consumidores que buscam características funcionais nos produtos, bem como aqueles orientados para dietas saudáveis tem apresentado um aumento e está aberto à novidades (OLIVEIRA et al., 2014).

Desse modo, vem sendo estudada a utilização de farinhas de arroz em formulações alimentícias como uma excelente estratégia para agregar valor nutritivo e propriedades funcionais a produtos isentos de glúten, sem elevar o seu custo final (OLIVEIRA, 2018; TORNISIELLO, 2019).

Diante do exposto, este trabalho teve por objetivo elaborar e analisar as caraterísticas físico-químicas de bolinhos fritos de farinha de arroz (Oryza sativa L.), como uma alternativa de alimento sem glúten.

\section{MATERIAIS E MÉTODOS}

A farinha foi elaborada pela moagem em liquidificador industrial e a peneiragem dos grãos de arroz parboilizado branco e integral foi realizada utilizando peneira de 60 mesh, obtidos no comércio local. Para a produção dos bolinhos fritos de arroz, foram elaboradas duas formulações conforme as concentrações dos ingredientes apresentadas na Tabela 1.

Tabela 1- Formulação dos bolinhos fritos com farinha de arroz branco parboilizado e integral

\begin{tabular}{|c|c|c|}
\hline Matéria-prima/ Ingredientes & (F1) (\%) & (F2) (\%) \\
\hline Arroz cozido (branco) & 55 & - \\
\hline Arroz cozido (integral) & - & 55 \\
\hline Água do cozimento (branco) & 18 & - \\
\hline Água do cozimento(integral) & - & 18 \\
\hline Farinha de arroz (branco) & 14 & - \\
\hline Farinha de arroz (integral) & - & 14 \\
\hline Ovo & 10 & 10 \\
\hline Queijo ralado & 1 & 1 \\
\hline Queijo mussarela & 1 & 1 \\
\hline Sal & 1 & 1 \\
\hline
\end{tabular}

Onde: F1 (Formulação 1) e F2 (Formulação 2)

Os ingredientes foram pesados, após, foi realizada a mistura do arroz cozido, sal e queijo ralado em liquidificador industrial, em seguida a mistura foi colocada em um recipiente de plástico e adicionou-se a farinha de arroz, água do cozimento e ovos, misturando-os com uma colher, até a formação de uma pasta homogênea, posteriormente, a massa foi pesada em divisões de $20 \mathrm{~g}$ e modelada, em sequência, foi colocado queijo mussarela como recheio e empanado com gema e farinha de aveia, e por fim, foram fritos em óleo de soja vegetal, em temperatura de aproximadamente $180^{\circ} \mathrm{C}$.

As análises de determinação do teor de umidade foram realizadas pelo método descrito pelo (IAL, 2008); de cor CIELab com colorímetro (GretagMacbeth Color-Eye 2180) e lipídeos (AOAC, 2005). As médias foram 
comparadas no excel pelo teste de t Student para verificar diferença significative ao nível de 5\% de significância.

\section{RESULTADOS E DISCUSSÃO}

A adição de arroz branco parboilizado e integral nas formulações F1 (com arroz branco parboilizado) e F2 (com arroz integral) influenciou significativamente nos teores de água e lipídeos, conforme apresentados na tabela 2.

Tabela 2- Caracterização físico-química do Bolinho frito com Farinha de Arroz

\begin{tabular}{|c|c|c|}
\multicolumn{2}{|c}{ Parâmetros } & \multicolumn{2}{c|}{ F1 } & F2 \\
\hline Teor de água (\%) & $50,47^{\mathrm{b}} \pm 1,27$ & $52,18^{\mathrm{a}} \pm 0,90$ \\
\hline $\mathrm{a}_{\mathrm{w}}$ & $0,99^{\mathrm{a}} \pm 0,00$ & $0,98^{\mathrm{b}} \pm 0,00$ \\
\hline Lipídeos & $7,11^{\mathrm{b} \pm 0,47}$ & $11,50^{\mathrm{a}} \pm 0,89$ \\
\hline
\end{tabular}

Médias \pm desvio padrão. Médias seguidas de letras minúsculas iguais na mesma linha não diferem entre si pelo teste $t$ Student $(\mathrm{p} \leq 0,05)$.

0 teor de água e de lipídeos do grão de arroz parboilizado cozido é de 69,1\% e 0,2 \% respectivamente e do arroz integral é de 70,1\% e $1 \%$ de acordo com a TACO (2011). Analisando os dados foi possível perceber que naturalmente o arroz integral apresenta maior teor de água e maior percentual de lipídeos do que o arroz branco e essa característica influenciou nos resultados das formulações dos bolinhos fritos de arroz. Foi possível também perceber que a fritura pode ter contribuído para a redução do teor de água das formulações, assim como o aumento do teor de lipídeos.

Já quanto os resultados dos parâmetros de cores avaliados obtidos, verificou-se que as formulações depois da fritura apresentaram diferença significativa e a F2 apresentou tendência de mais escura ${ }^{*} \mathrm{~L}$, cor avermelhada e amarelada (*a e b*) menos intensa, conforme apresentados na Tabela 3.

Tabela 3. Médias para análise de cor dos bolinhos fritos (F1 e F2)

\begin{tabular}{|c|c|c|c|}
\hline Parâmetros de cor & F1 & \multicolumn{2}{|c|}{ F2 } \\
\hline$L^{*}$ & & $32,94^{\mathrm{a}} \pm 0,27$ & $20^{\mathrm{b}} \pm 0,45$ \\
\hline $\mathrm{a}^{*}$ & & $12,35^{\mathrm{a}} \pm 0,08$ & $9,54^{\mathrm{b}} \pm 0,06$ \\
\hline $\mathrm{b}^{*}$ & & $29,92^{\mathrm{a}} \pm 0,10$ & $24,08^{\mathrm{b}} \pm 0,06$ \\
\hline
\end{tabular}

Médias \pm desvio padrão. Médias seguidas de letras minúsculas iguais na mesma linha não diferem entre si pelo Teste $\mathrm{t}$ Student $(\mathrm{p} \leq 0,05) . \mathrm{L}^{*}$ - Luminosidade, $\mathrm{a}^{*}$ - negativo (verde), a* positivo (vermeho), $\mathrm{b}^{*}$ - positivo (amarelo), negativo (azul)

\section{CONCLUSÃO}

A partir dos resultados obtidos foi possível observar que a diferença na composição dos tipos de arroz utilizados para a produção da farinha influenciou na composição dos bolinhos fritos, assim como a fritura. 


\section{REFERÊNCIAS}

[1] ACELBRA. Associação dos Celíacos do Brasil. Disponível em: <http://www.acelbra.org.br>. Acesso em: 01 set. 2020.

[2] AOAC - Association of Official Analytical Chemistry. Official Methods of Analysis of the AOAC International, 16 ed, Arlington: AOAC, 2005, 1025p.

[3] BASSINELlO, P. Z.; LUZ, T. C. L. A.; FERREIRA, C. M.. Farinha de Arroz: Alternativa Alimentar e Econômica. Empresa Brasileira de Pesquisa Agropecuária. Embrapa Arroz e Feijão. Ministério da Agricultura, Pecuária e Abastecimento, 2017.

[4] IAL - INSTITUTO ADOLFO LUTZ. Normas analíticas, métodos químicos e físicos para análises de alimentos. $4^{\underline{a}}$ ed. 1a ed. Digital,1020p., São Paulo, 2008.

[5] OLIVEIRA, C. A. O.; ANSELMI, A. A.; KOLLING, D. F.; FINGER, M. I. F.; DALLA CORTE, V. F.; DILL, M. D. Farinha de arroz e derivados como alternativas para a cadeia produtiva do arroz. Revista Brasileira de Produtos Agroindustriais, Campina Grande, v. 16, n. 1, p. 61-67, 2014.

[6] OLIVEIRA, M. C. Desenvolvimento de bolo à base de farinha de feijão-caupi e arroz. Orientador: Prof. Dr. Ferlando Lima Santos. 2018. TCC (Bacharelado em Nutrição) - Universidade Federal do Recôncavo Baiano, 2018.

[7] TORNISIELLO, A. L. Farinha de arroz como alternativa tecnológica para o desenvolvimento de biscoitos sem glúten e veganos. Orientador: Dr.Pedro Luiz Manique Barreto. 2019. TCC (Graduação em Ciência e Tecnologia de Alimentos) - Universidade Federal de Santa Catarina, 2019. 


\title{
Capítulo 8
}

\section{Atividade antioxidante de hidrolisados proteicos de feijão preto (Phaseolus vulgaris L.)}

\author{
Jarine Amaral do Evangelho \\ José de Jesus Berrios \\ Mariana Dias Antunes Porto \\ Nathan Levien Vanier \\ Vânia Zanella Pinto \\ Elessandra da Rosa Zavareze
}

Resumo: 0 objetivo deste trabalho foi estudar o efeito da hidrólise enzimática do concentrado proteico de feijão preto utilizando diferentes enzimas e avaliar o perfil eletroforético e atividade antioxidante dos hidrolisados. Proteínas de feijão foram extraídas e hidrolisadas por um período de 120 min utilizando as enzimas pepsina ou Alcalase. 0 perfil eletroforético foi avaliado por eletroforese e a atividade antioxidante pelos métodos de captação de radicais livres ABTS •+ e DPPH. Houve desaparecimento das bandas superiores a $50 \mathrm{kDa}$ quando a proteína de feijão foi submetida a hidrólise com pepsina. 0 hidrolisado proteico de feijão obtido pela ação da enzima Alcalase apresentou atividade antioxidante superior para inibição dos radicais ABTS •+, entretanto pelo método de DPPH os hidrolisados de pepsina tiveram maiores valores. Concluiu-se que a utilização de diferentes enzimas no preparo de hidrolisados proteicos de feijão preto em um mesmo tempo de reação proporcionou diferentes perfis de peso molecular e hidrolisados com capacidade antioxidante superior à proteína nativa.

Palavras-chave: Antioxidante, feijão, peso molecular, proteína. 


\section{INTRODUÇÃO}

O feijão (Phaseolus vulgaris L.) é a espécie do gênero Phaseolus mais produzida e consumida no mundo. Os feijões quebrados, também conhecidos como bandinhas de feijão são provenientes dos processos de colheita e pós-colheita dos grãos e apresentam o mesmo valor nutricional dos grãos inteiros, entretanto baixo valor comercial. A abertura dos cotilédones aumenta a exposição dos componentes do grão ao meio ambiente, o que favorece as reações físicas e químicas, indicando assim a necessidade do seu consumo em menor tempo que os grãos inteiros (CARVALHO et al., 2012). Uma forma de agregar valor a esses grãos quebrados é a extração de suas proteínas (AMARAL et al, 2017).

Os hidrolisados proteicos têm sido utilizados no preparo de alimentos com alta digestibilidade proteica e com a presença de grupos seletos de aminoácidos. Esses alimentos são fundamentais para pessoas que apresentam doenças crônicas que dificultam a absorção das proteínas na sua forma nativa - doenças de Crohn e Síndrome do intestino curto, por exemplo - ou que impossibilitam o consumo de aminoácidos específicos - como exemplo a Fenilcetonúria, as alergias e intolerâncias alimentares (PACHECO et al., 2005). Outro campo de aplicação dos hidrolisados proteicos é a nutrição esportiva, especialmente em exercícios de resistência e musculação, pois os aminoácidos e peptídeos são precursores da síntese proteica exercendo assim um papel fundamental na recuperação mais rápida pós-treino e promovendo uma melhora na performance do atleta.

Pesquisas realizadas com peptídeos obtidos pela hidrólise enzimática de proteínas extraídas de diferentes fontes alimentares têm demonstrado, além do seu valor nutritivo, efeitos benéficos a saúde humana. Estes estudos envolvem enzimas comerciais (alcalase, flavourzyme, pepsina, pancreatina, tripsina, quimiotripsina, neutrase, etc.) em diferentes tempos de hidrólise e proporções de enzima/substrato sob condições ótimas de pH e temperatura para cada enzima especifica. As condições de preparo do hidrolisado e especificidade da enzima é um fator chave na hidrólise, pois afeta o número e a localização das ligações peptídicas que estão sendo hidrolisadas, produzindo assim hidrolisados com diferentes peptídeos que terão diferentes propriedades biológicas e funcionais. Dentre estes efeitos, estão: atividade anti-hipertensiva, atividade antioxidante, atividade antimicrobiana, atividade anticarcinogênica e atuação no controle do metabolismo lipídico (ROY; BOYE; SIMPSON, 2010).

De acordo com ZHAO et al. (2011) as propriedades bioativas dos hidrolisados estão relacionados à modificação da conformação e estrutura da proteína, sendo associados a diminuição do peso molecular, aumento dos grupamentos ionizáveis e a exposição de grupos hidrofóbicos, até então ocultos das proteínas. 0 objetivo deste trabalho foi estudar o efeito da hidrólise enzimática do concentrado proteico de feijão preto, utilizando enzimas pepsina e alcalase, sobre o perfil eletroforético e atividade antioxidante pelos métodos DPPH e $\mathrm{ABTS}^{\bullet+}$

\section{MATERIAL E MÉTODOS}

Foram utilizados grãos de feijao preto, cv. BRS , obtidos no comércio local da cidade de Pelotas, Rio Grande do Sul, Brasil. Os concentrados proteicos foram preparados conforme descrito por CARRASCO-CASTILLA et al. (2012), com algumas modificações. As hidrólises enzimáticas foram realizadas de acordo com os mesmos autores. Inicialmente, o concentrado proteico foi suspenso em tampão fosfato de sódio $35 \mathrm{mmol} / \mathrm{L}$ para obter uma solução $5 \%(\mathrm{p} / \mathrm{v})$.

0 material permaneceu sob agitação overnight a $4{ }^{\circ} \mathrm{C}$. 0 processo de hidrólise foi realizado sob condições controladas (temperatura, $\mathrm{pH}$ e agitação) com proporção enzima/substrato de $1 / 20$. A temperatura foi mantida a $37^{\circ} \mathrm{C}$ e o $\mathrm{pH}$ a 2,0 quando se realizou a hidrólise com pepsina. Para enzima Alcalase, a temperatura utilizada foi de $50{ }^{\circ} \mathrm{C}$ e o pH 7,0. Após 120 minutos de reação, as amostras foram imediatamente aquecidas a $90 \stackrel{\circ}{\circ}$ por 10 min para a inativação enzimática. 0 material foi centrifugado a $13000 \mathrm{rpm}$ durante 15 min. $\mathrm{O} \mathrm{pH}$ do sobrenadante foi ajustado para 7 , coletado e liofilizado.

A determinação do perfil eletroforético do concentrado proteico de feijão preto e dos hidrolisados proteicos a partir de pepsina e Alcalase foi realizado de acordo com procedimento descrito por Laemmli (1970). A capacidade inibidora de radicais livres ABTS $\bullet+$ do concentrado e dos hidrolisados proteicos de feijão preto foi realizada segundo o método descrito por Durak et al. (2013). A eliminação de radicais livres DPPH foi analisada de acordo com o método de Xia et al. (2012). Foi realizada a análise de variância (ANOVA) e comparação de médias pelo teste de Tukey, a 5\% de significância. 


\section{RESULTADOS E DISCUSSÕES}

Na Figura 1 estão apresentados os perfis eletroforético por SDS-PAGE do concentrado proteico e dos hidrolisados proteicos de feijão. Na primeira coluna do gel (Std) encontra-se o padrão de proteínas com peso molecular conhecido e nas demais, do concentrado proteico de feijão preto (A) e dos hidrolisados obtidos a partir de pepsina (B) e Alcalase (C), respectivmente.

A faseolamina (fração 7s) é a maior proteína de armazenamento do feijão, sendo essa a principal fração das globulinas e representando cerca de 40 a $50 \%$ das proteínas do grão. Essa proteína oligomérica é composta de três subunidades polipeptídicas $-\alpha, \beta$ e $\gamma$ - com massa molecular entre 43 a $53 \mathrm{kDa}$ (YIN et al., 2008). Enquanto a outra fração globulínica das leguminas (fração 11S) representam apenas 10\% (MONTOYA et al., 2010). As bandas no gel correspondentes a fração faseolina ( $47 \mathrm{kDa}$ e $44 \mathrm{kDa}$ ) foram observadas tanto para o concentrado proteico de feijão como para todos os hidrolisados. A banda de $31 \mathrm{kDa}$ de PHA também foi visível para o concentrado e todos os hidrolisados. Essas bandas também foram observadas por Moralesde-Leon et al. (2007) para concentrados proteicos de feijão novo e endurecido (Phaseolus vulgaris L.).

Além disso, as bandas de proteínas superior a $50 \mathrm{kDa}$ observadas no concentrado proteico de feijão desapareceram nos hidrolisados obtidos a partir de pepsina (B). De acordo com Makri et al. (2006), os pesos moleculares acima de $57 \mathrm{kDa}$ correspondem a fração $11 \mathrm{~S}$ das proteínas de armazenamento. Assim, o desaparecimento das bandas entre 45-66 kDa após a hidrólise com pepsina é um indicativo da quebra das proteínas 11S.

Figura 1. Perfil de eletroforese do concentrado proteico de feijão preto e hidrolisados. STD: proteínas padrão; A: concentrado proteico de feijão preto (Controle); B e C- Hidrolisados proteicos com 120 min de reação para pepsina e Alcalase, respectivamente

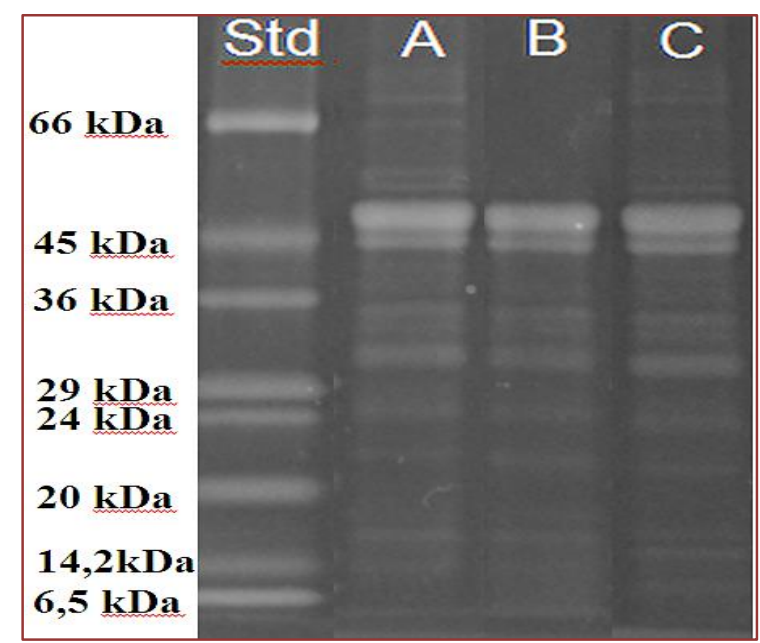

As propriedades antioxidantes dos hidrolisados obtidos com diferentes tempos de hidrólise estão apresentados na Tabela 1. A atividade antioxidante dos hidrolisados foram avaliados com base em sua capacidade de eliminar radical livres $\mathrm{ABTS}^{\bullet}+\mathrm{e}$ DPPH.

Tabela 1. Atividade antioxidante do concentrado e hidrolisados proteicos de feijão

\begin{tabular}{|c|c|c|}
\hline Tratamento & ABTS \\
CPFP & DPPH \\
\hline HPFPP 120 min & $55,32 \pm 0,08 \mathrm{~b}$ & $39,45 \pm 0,77 \mathrm{~b}$ \\
\hline HPFPA 120 min & $63,56 \pm 0,44 \underline{\mathbf{a}}-$ & $37,15 \pm 0,27 \mathrm{c}$ \\
\hline
\end{tabular}

*Letras iguais na mesma coluna não diferem estatisticamente entre si pelo teste de tukey. CPFP-

Concentrado proteico de feijão preto, HPFPP- Hidrolisado proteico de feijão preto pepsina, HPFPA-

Hidrolisado proteico feijão preto Alcalase.

0 hidrolisado proteico de feijão obtido com Alcalase apresentou atividade antioxidante superior para inibição dos radicais $\mathrm{ABTS}^{\bullet}$, quando comparado ao concentrado proteico de feijão preto (controle) e ao hidrolisado com pepsina. Segundo Re et al. (1999) o $\mathrm{ABTS}^{\bullet+}$ é capaz de se ligar com radicais hidrofóbicos e 
hidrofílicos da proteína. A maior atividade antioxidante pelo método de $\operatorname{ABTS}^{\bullet+}$, do hidrolisado proteico obtidos com a ação da Alcalase possivelmente é atribuído a maior exposição de grupamentos hidrofóbicos antes encobertos na estrutura enovelada original da proteína.

No entanto, ao analisar a da atividade antioxidante para inibição do radical DPPH, pode-se observar que o hidrolisado proteico obtido com a pepsina apresentou valores superiores ao hidrolisado com Alcalase. Ortiz-Valdez et al. (2012) estudaram hidrolisados proteicos de feijão Azufrado (Phaseolus vulgaris) obtidos com a enzima pepsina durante 2 horas de hidrólise e verificaram 44\% de inibição do radical DPPH e 73\% de inibição do radical $\mathrm{ABTS}^{\bullet+}$.

Como se pode observar na Figura 1, os hidrolisados de pepsina (B) apresentaram bandas mais acentuadas entre 14,3 e 6,5 kDa devido a quebra de proteínas de alto peso molecular. Embora, ZHAO et al. (2011) tenha associado a redução de peso molecular das proteínas com sua atividade antioxidante, nesse estudo não foi observada essa relação, pois os hidrolisados de Alcalase apresentaram elevada capacidade de inibição de radicais.

\section{CONCLUSÕES}

A utilização de diferentes enzimas no preparo de hidrolisados proteicos de feijão preto em um mesmo tempo de reação proporciona diferentes perfis de peso molecular por Eletroforese (SDS-PAGE). O hidrolisado proteico de feijão preto com a enzima Alcalase apresentou maior atividade antioxidante pelo método de inibição do radical $\mathrm{ABTS}^{\bullet+}$. Os hidrolisados proteicos de feijão preto obtidos pela enzima Alcalase fomentam uma nova perspectiva de produtos na indústria alimentícia, pois além de obter um suplemento alimentar de proteínas vegetais com melhores propriedades de digestibilidade devido ao processo de hidrólise, contempla ainda a proposta de ser alimento bioativo tendo em vista sua capacidade antioxidante.

\section{REFERÊNCIAS}

[1] AMARAL, J. E.; VANIER, NATHAN LEVIEN ; PINTO, VÂNIA ZANELLA ; BERRIOS, JOSE J. DE ; DIAS, A. R. G. ; Zavareze, Elessandra da Rosa . Black bean (Phaseolus vulgaris L.) protein hydrolysates: Physicochemical and functional properties. FOOD CHEMISTRY, v. 214, p. 460-467, 2017.

[2] CARRASCO-CASTILlA, J.; HERNANDEZ-ALVAREZ, A. J.; JIMENEZ-MARTINEZ, C., JACINTO HERNADEZ, C.; ALAIZ, M. GIRON-GALLE, J.; VIOQUE, J.; DAVILA-ORTIZ, G. Antioxidant and metal chelating activities of Phaseolus vulgaris L. var. Jamapa protein isolates, phaseolin and lectin hydrolysates. Food Chemistry, v. 131, n. 4, p. 1157-1164, 2012.

[3] CARvalho, A. V.; BASSinelo, P. Z.; MATTIETTO, R. A.; CARVAlHO. R. N.; RiOS, A. O.; SECCADIO, L. L. Processamento e caracterização de snack extrudado a partir de farinhas de quirera de arroz e de bandinha de feijão. Brazilian Journal of Food Technology, v. 15, n. 1, p. 72-83, 2012.

[4] DURAK. A.; BARANIAK, B.; JAKUBCZYK, A.; ŚWIECA, M. Biologically active peptides obtained by enzymatic hydrolysis of Adzuki bean seeds. Food Chemistry, v. 141, n. 3, p. 2177-2183, 2013.

[5] LAEMMLI, U. K. Cleavage of structural proteins during the assembly of the head of the head of bacteriophage T4. Nature. v. 227, n.1, p. 680-685, 1970.

[6] MAKRI, E. A.; DOXASTAKIS, G. I. Emulsifying and foaming properties of Phaseolus vulgaris and coccineus proteins. Food Chemistry, v. 98, n. 3, p. 558-568, 2006.

[7] ORTIZ-VALDEZ, A.; FUENTES-GUTIÉRREZ, C. I.; GERMÁN-BÁEZ, L. J.; GUTIÉRREZ-DORADO, R.; MEDINAGODOY, S. Protein hydrolysates obtained from Azufrado (sulphur yellow) beans (Phaseolus vulgaris): Nutritional, ACEinhibitory and antioxidative characterization. LWT - Food Science and Technology, v. 46, v. 1, p. 91-96, 2012.

[8] RE, R.; PELEGRINI, N.; PROTEGGEnTE, A.; PANNAlA, A.; YANG, M.; RICE-EVANS, C. Antioxidant activity applying an improved ABTS radical cation decolorization assay, Free Radical Biology \& Medicine, v. 26, n. 9, p. 12311237, 1999.

[9] ROY, F.; BOYE, J. I.; SIMPSON, B. K. Bioactive proteins and peptides in pulse crops: Pea, chickpea and lentil. Food Research International, v. 43, n.2, p. 432-442, 2010.

[10] XIA Y, BAMDAD F, GÄNZLE M, CHEN L. Fractionation and characterization of antioxidant peptides derived from barley glutelin by enzymatic hydrolysis. Food Chemistry; v.134, n. 3, 1509-1518, 2012.

[11] ZHAO, G.; LIU, Y.; ZHAO, M.; REN, J.; YANG, B. Enzymatic hydrolysis and their effects on conformational and functional properties of peanut protein isolate. Food Chemistry, v. 127, n. 4, p. 1438-1443, 2011. 


\title{
Capítulo 9
}

Modelagem da solubilidade do $\beta$-sitosterol em solventes orgânicos usando o modelo NRTL

\author{
Vanessa Vilela Lemos \\ Karolina Soares Costa \\ Jéssica Cristina Silva Resende \\ Marlus Pinheiro Rolemberg \\ Rodrigo Corrêa Basso
}

Resumo: 0 destilado de desodorização é uma mistura contendo fitoesteróis originada do processo de desodorização dos óleos vegetais. Os fitoesteróis apresentam importância tecnológica, sendo empregados nas indústrias alimentícias e farmacêuticas apresentando estrutura molecular similar entre si, sendo o $\beta$ - sitosterol um dos compostos majoritários desta classe. A extração dos fitoesteróis do destilado de desodorização normalmente é feita por um conjunto de etapas complexas e de alto custo. 0 processo de dissolução fracionada pode vir a ser uma alternativa simples para esta extração. Neste processo, o conhecimento da solubilidade dos fitoesteróis em diferentes solventes orgânicos, tornase essencial. Deste modo, o presente trabalho estudou a modelagem termodinâmica do equilíbrio sólido-líquido do $\boldsymbol{\beta}$ - sitosterol em metanol, acetato de etila, acetona, etanol e n-hexano por meio do modelo NRTL. Os devios relativos médios entre as temperaturas calculadas e as experimentais ficaram entre $-0,54 \%$ e $0,28 \%$, mostrando a boa representatividade da solubilidade por este modelo termodinâmico. 


\section{INTRODUÇÃO}

A desodorização é a última etapa do processo de refino de óleos vegetais e consiste na retirada de componentes por meio de um processo de esgotamento, realizado com vapor de água superaquecido, a elevadas temperaturas $\left(220\right.$ a $\left.260{ }^{\circ} \mathrm{C}\right)$ e baixas pressões $(2-4$ mbar $)$. No processamento de óleos com elevada concentração de ácidos graxos livres a desodorização é a responsável por promover a remoção destes componentes até concentrações entre 0,03 e 0,05\% (m/m), sendo conduzida sob condições operacionais mais intensas, utilizando maior tempo de processo, maiores temperaturas e menor pressão. 0 material removido nesta operação é conhecido como destilado de desodorização (DD), e sua composição depende do óleo processado e das condições operacionais empregadas. Os componentes dos DDs provenientes de diferentes óleos são os ácidos graxos livres, acilgliceróis parciais, tocóis (tocoferóis e tocotrienóis), esteróis e esqualeno (de GREYT; KELLENS, 2005).

Os fitoesteróis, são os compostos predominantes na fração insaponificável dos óleos vegetais, possuindo elevada similaridade entre si quanto a sua estrutura molecular. Estão presentes tanto na forma livre quanto na forma esterificada com ácidos graxos. Os principais esteróis presentes como componentes minoritários da maioria dos óleos são do grupo 4-desmetil-esterol, embora os grupos 4-metil-esterol e 4,4-dimetilesterol (também conhecidas como alcoois triterpenicos) estejam presentes nestes óleos. Salvo algumas exceções, o $\beta$-sistosterol é geralmente o componente mais abundante, acompanhado por concentrações variáveis de campesterol, estigmasterol, $\Delta 5$-avenasterol e outros esteróis (VAIKOUSI et al., 2007). No óleo bruto de arroz a concentração de fitoesteróis totais pode ser de até $2,9 \%$, sendo o $\beta$-sitosterol responsável por mais de um quarto desta composição, atingindo 27,8 \% deste valor. Por sua vez, no DD do óleo de arroz os fitoesteróis compõem aproximadamente $14,8 \%(\mathrm{~m} / \mathrm{m})$ da mistura de componentes, com o $\beta$-sitosterol perfazendo mais de $40,0 \%$ deste total. (HOED et al., 2006)

Os fitoesteróis e seus derivados possuem importantes atividades benéficas à saúde, tendo sido reportadas suas atividades antioxidante, anti-inflamatória, anticancerígena e hipocolesterolêmica (MOREAU; WITHAKER; HICKS, 2002). Quanto ao interesse de sua aplicação tecnológica, os fitoesteróis podem ser utilizados como modificadores das propriedades físicas e do comportamento de cristalização de bases lipídicas, levando a redução da presença de ácidos graxos saturados nestas formulações (GODOI et al. 2017).

Os estudos voltados a extração de fitoesteróis dos DDs normalmente envolvem uma série de etapas complexas de processos de separações físicas e/ou químicas que resultam em altos custos operacionais, quando não na inviabilização econômica em escala industrial dos mesmos. A partir do DD de óleo de soja, utilizando-se como forma de extração/purificação quatro etapas em série de destilação molecular, foram alcançadas concentrações finais de $23,3 \%$ e de 19,1 \% respectivamente para tocóis (tocoferóis e tocotrienóis) e fitoesteróis (ITO et al., 2005). A utilização em série de saponificação, esterificação, cristalização e filtração sob vácuo foi utilizada separação e purificação de fitoesteróis do DD de óleo de soja até uma pureza final de 94,7 \% (Yan et al., 2012).

A dissolução fracionada pode vir a ser uma alternativa menos complexa e de menor custo do que as tecnologias que têm sido estudadas para a separação e concentração de fitoesteróis dos DDs de óleos vegetais. A separação dos componentes de interesse neste tipo de processo é resultado da solubilidade diferenciada daqueles em diferentes solventes e temperatura. A descrição do comportamento da solubilidade dos fitoesteróis, por meio do equilíbrio sólido-líquido, utilizando modelos termodinâmicos é importante ao estudo de processos de separação e purificação daqueles componentes uma vez que com uma reduzida quantidade de dados experimentais pode-se representar o comportamento destes em uma faixa de temperaturas. Adicionalmente estes modelos são usados em simulações computacionais, que são a base para o desenvolvimento de processos em escala industrial.

O objetivo do presente trabalho foi ajustar parâmetros para o modelo termodinâmico NRTL, a partir de dados reportados por Wei et al., (2010), para descrever a solubilidade do $\beta$-sitosterol, componente normalmente encontrado em maior abundância nos fitoesteróis provenientes de óleos vegetais, em metanol, etanol, acetona, acetato de etila e n-hexano.

\section{MÉTODO}

Foi realizado o ajuste de parâmetros do modelo NRTL para o cálculo do coeficiente de atividade para a descrição do equilíbrio sólido-líquido dos sistemas constituídos por $\beta$-sitosterol (1) + metanol (2), $\beta$ sitosterol (1) + etanol (3), $\beta$-sitosterol (1) + acetona (4), $\beta$-sitosterol (1) + acetato de etila (5) e $\beta$-sitosterol (1) + n-hexano (6). 
Na modelagem termodinâmica, o equilíbrio sólido-líquido foi descrito por meio da equação (1):

$$
\ln \gamma_{1} \cdot \mathrm{x}_{1}=\frac{-\Delta \mathrm{H}_{\mathrm{m}}}{\mathrm{R} \cdot \mathrm{T}}\left(1-\frac{\mathrm{T}}{\mathrm{T}_{\mathrm{m}}}\right)
$$

onde $\gamma_{1}$ é o coeficiente de atividade do soluto na fase líquida; $\mathrm{x}_{1}$ é a fração molar do soluto na fase líquida; $\mathrm{R}$ é a constante universal dos gases $\left(\mathrm{J} \cdot \mathrm{mol}^{-1} \cdot \mathrm{K}^{-1}\right) ; \Delta \mathrm{H}_{\mathrm{m}}$ é a entalpia de fusão do soluto $\left(\mathrm{J} \cdot \mathrm{mol}^{-1}\right) ; \mathrm{T}_{\mathrm{m}}$ é a temperatura $(\mathrm{K})$ de fusão do soluto e $\mathrm{T}(\mathrm{K})$ é a temperatura do sistema.

A entalpia de fusão e a temperatura de fusão do $\beta$-sitosterol utilizadas na equação (1) respectivamente, 407,25 K e 41,2 J · $\mathrm{g}^{-1}$, segundo reportadas por Panpipat et al., (2013).

O coeficiente de atividade da fase líquida é calculado por meio do modelo NRTL para um sistema binário qualquer, segundo a equação:

$$
\begin{aligned}
& \ln \gamma_{1}=x_{2}^{2}\left[\tau_{21}\left(\frac{G_{21}}{x_{1}+x_{2} G_{21}}\right)^{2}+\frac{\tau_{12} G_{12}}{\left(x_{2}+x_{1} G_{12}\right)^{2}}\right] \\
& \ln \gamma_{2}=x_{1}^{2}\left[\tau_{12}\left(\frac{G_{12}}{x_{2}+x_{1} G_{12}}\right)^{2}+\frac{\tau_{21} G_{21}}{\left(x_{1}+x_{2} G_{21}\right)^{2}}\right]
\end{aligned}
$$

onde $G_{12}$ e $G_{21}$ são os parâmetros de interação energética entre o soluto (1) e o solvente (2), calculados pelas equações:

$$
\begin{aligned}
& G_{12}=e^{\left(-\alpha_{12} \tau_{12}\right)} \\
& G_{21}=e^{\left(-\alpha_{12} \tau_{21}\right)}
\end{aligned}
$$

onde $\alpha$ é o parâmetro de não aleatoriedade; $\tau_{12}$ e $\tau_{21}$.são definidos pelas equações:

$$
\begin{aligned}
& \tau_{12}=\frac{\left(g_{12}-g_{22}\right)}{R T}=\frac{\Delta g_{12}}{R T} \\
& \tau_{21}=\frac{\left(g_{21}-g_{11}\right)}{R T}=\frac{\Delta g_{21}}{R T}
\end{aligned}
$$

onde $\mathrm{g}_{12}$ são os parâmetros de interação energética entre o soluto (1) e o solvente (2); $\Delta \mathrm{g}_{12}$ e $\Delta \mathrm{g}_{21}$ são os valores ajustados para a fase líquida a partir dos dados experimentais.

Os desvios relativos médios (DRM) e os desvios relativos (DR) foram calculados usando as equações () e (5), como a seguir:

$$
\begin{aligned}
& \operatorname{DRM}(\%)=100 \cdot \sum\left(\frac{\left|\mathrm{T}^{\mathrm{exp}}-\mathrm{T}^{\text {calc }}\right|}{\mathrm{T}^{\exp }}\right) \\
& \operatorname{DR}=100 \cdot \frac{\mathrm{T}^{\exp }-\mathrm{T}^{\mathrm{calc}}}{\mathrm{T}^{\exp }}
\end{aligned}
$$

onde $\mathrm{T}^{\exp }$ é a temperatura $(\mathrm{K})$ experimental; $\mathrm{T}^{\text {calc }}$ é a temperatura $(\mathrm{K})$ calculada. 


\section{RESULTADOS E DISCUSSÕES}

A equação que descreve o equilíbrio sólido-líquido, usando o coeficiente de atividade calculado pelo modelo termodinâmico NRTL, representou adequadamente o equilíbrio sólido-líquido para os cinco sistemas, em todas as faixas de temperatura de estudo, conforme observado pela sobreposição das curvas calculadas com os dados experimentais, na Figura 1.

Os solventes que apresentaram maior e menor solubilidade para o $\beta$-sitosterol foram, respectivamente, o acetato de etila e o metanol em toda a faixa de temperatura estudada. .A menor diferença de solubilidade do soluto nestes solventes ocorreu para a temperatura de 278,15 K, e a maior diferença de solubilidade se deu para na temperatura 323,15 K, com o éster solubilizando, respectivamente, 26,4 e 32,9 vezes a fração molar do $\beta$-sitosterol em comparação ao álcool.

Figura 1. Comportamento do equilíbrio sólido-líquido: dados experimentais (Wei et al., 2010) e calculados a partir do modelo NRTL para os sistemas $\beta$-sitosterol + metanol $(\mathbf{\square}), \beta$-sitosterol $+\mathrm{n}$-hexano $(\mathrm{X}), \beta$ sitosterol + etanol $(\mathbf{A}), \beta$-sitosterol + acetona $(\bullet), \beta$-sitosterol + acetato de etila $(+)$

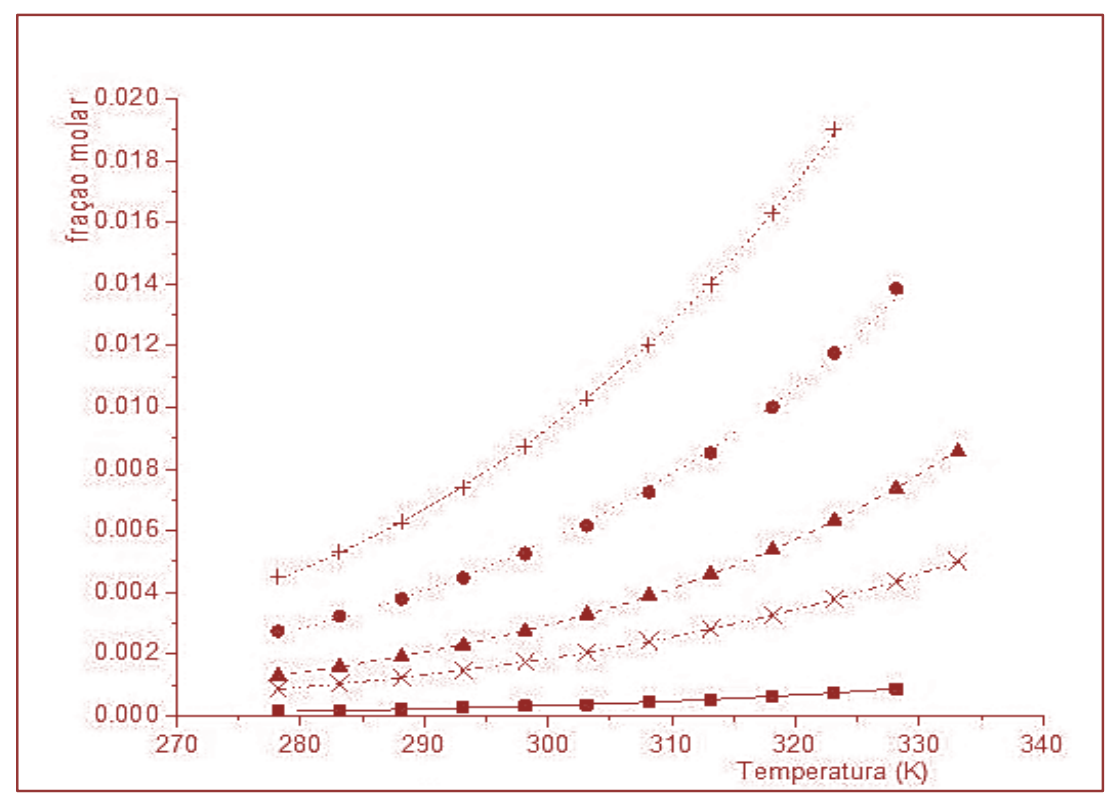

A maior faixa de desvio entre as temperaturas calculadas e experimentais ocorreu para o sistema contendo metanol, enquanto a menor ocorreu o sistema contendo n-hexano, com uma variação máxima para o primeiro de $0,54 \%$, subestimando a temperatura calculada, conforme observado na Tabela 1.

A boa representatividade do modelo NRTL foi equivalente à reportada na literatura (Wei et al., 2010) utilizando a equação empírica apresentada por Apelblat e Manzurola (1999). 0 modelo empírico apresenta como desvantagem a falta fundamentação quanto ao significado físico dos parâmetros da equação, diferente do modelo termodinâmico NRTL cujos parâmetros são correlacionados à energia de interação entre os componentes e a não aleatoriedade de sua distribuição nos sistemas, dados respectivamente pelos parâmetros $\Delta \mathrm{g}$ e $\alpha$. Adicionalmente, o modelo termodinâmico NRTL pode ser usado diretamente em simuladores computacionais, a partir dos parâmetros previamente ajustados. 
Tabela 1. Desvios relativos e desvios relativos médios entre as temperaturas experimentais e calculadas utilizando a equação 1.

\begin{tabular}{|c|c|c|}
\hline & Faixa (\%) & Médio (\%) \\
\hline Metanol & $-0,54$ a 0,28 & 0,24 \\
\hline Etanol & $-0,07$ a 0,07 & 0,04 \\
\hline Acetona & $-0,40$ a 0,21 & 0,16 \\
\hline Acetato de etila & $-0,14$ a 0,10 & 0,05 \\
\hline N-hexano & $-0,04$ a 0,02 & 0,02 \\
\hline
\end{tabular}

Os parâmetros do modelo NRTL ajustados para os cinco sistemas estudados, são apresentados na Tabela 2.

Tabela 2. Parâmetros ajustados para o modelo termodinâmico NRTL a partir dos dados experimentais de Wei et. Al., (2010)

\begin{tabular}{|c|c|c|c|}
\hline & $\Delta \mathrm{g}_{\mathrm{ij}}\left(\mathrm{J} \cdot \mathrm{mol}^{-1}\right)$ & $\Delta \mathrm{g}_{\mathrm{ji}} \mathrm{J} \cdot\left(\mathrm{mol}^{-1}\right)$ & $\alpha$ \\
\hline 12 & 13899,8485 & 11021,6146 & 0,2000 \\
\hline 13 & 5830,0511 & 7353,1810 & 0,3123 \\
\hline 14 & 10538,1706 & 6938,4001 & 0,4280 \\
\hline 15 & 5342,9089 & 4595,5506 & 0,3103 \\
\hline 16 & 13201,2981 & 8258,1694 & 0,2786 \\
\hline
\end{tabular}

Conforme mostrado na Figura 2, os desvios relativos entre as temperaturas experimentais e calculadas foram muito próximo à diagonal do gráfico, sem demostrar tendência específica estarem localizados acima ou abaixo dela. Este comportamento confirma o adequado ajuste dos parâmetros do modelo na descrição da solubilidade do $\beta$-sitosterol nos solventes, sem qualquer tendência em subestimar ou superestimar os dados experimentais.

A adequada representatividade dos dados experimentais pelo modelo NRTL está relacionada a sua versatilidade no cálculo do coeficiente de atividade da fase líquida, uma vez que o mesmo foi desenvolvido para sistemas fortemente não ideais, como os abordados no presente estudo. 
Figura 2. Desvios relativos médios entre as temperaturas experimentais e calculadas para os sistemas $\beta$ sitosterol + metanol $(\boldsymbol{\square}), \beta$-sitosterol + n-hexano $(X), \beta$-sitosterol + etanol $(\mathbf{\Delta}), \beta$-sitosterol + acetona $(\bullet), \beta$ sitosterol + acetato de etila $(+)$

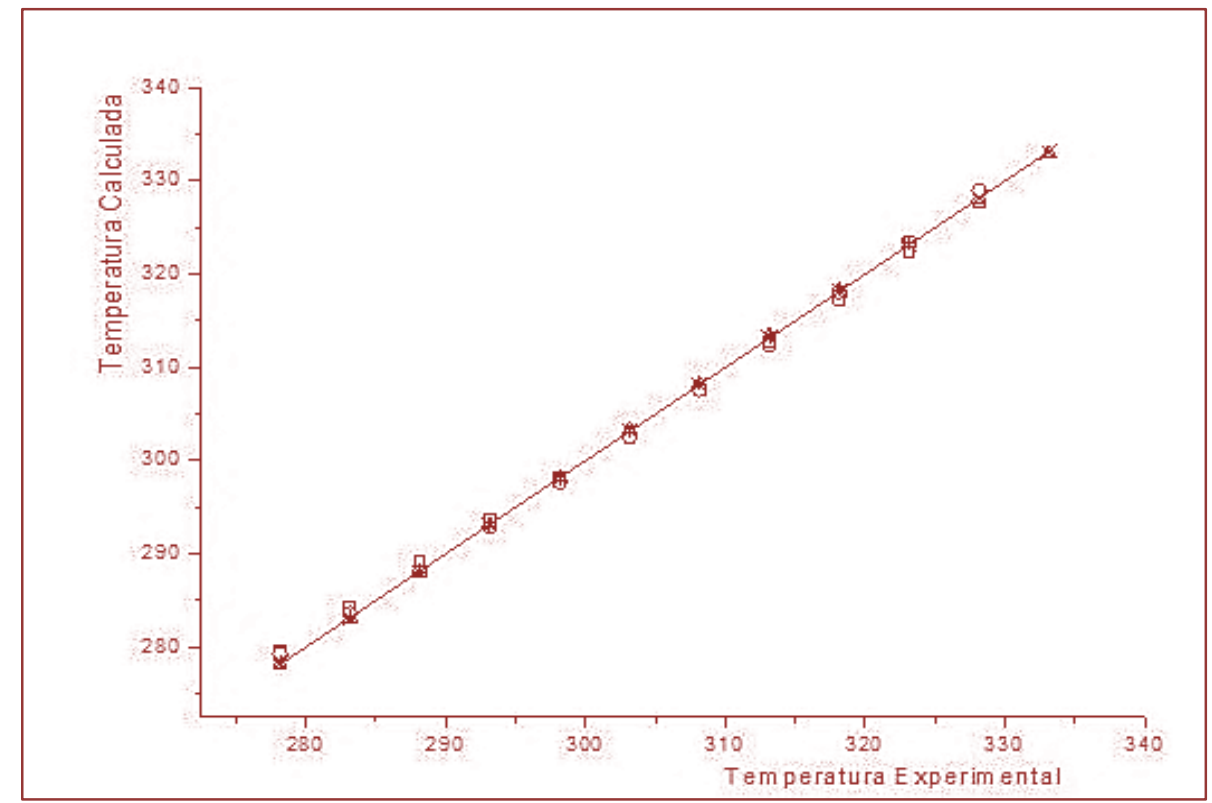

\section{CONCLUSÃO}

A modelagem termodinâmica da solubilidade do $\beta$-sitosterol em acetona, acetato de etila, etanol e n-hexano em função da temperatura, usando o modelo NRTL para cálculo do coeficiente de atividade da fase líquida, resultou em baixos desvios entre os valores experimentais e calculados, mostrando a adequada descrição do comportamento dos sistemas pelo modelo.

\section{AGRADECIMENTOS}

Os autores agradecem ao Conselho Nacional de Desenvolvimento Científico e Tecnológico (CNPq, Processo: 420355/2016-2) pelo apoio financeiro, à Coordenação de Aperfeiçoamento de Pessoal de Nível Superior (CAPES, Código de Financiamento 001) e à Fundação de Amparo à Pesquisa de Minas Gerais pelo apoio financeiro, (FAPEMIG, Processo: TEC - APQ - 01412-16) e pela bolsa de estudos da discente Vanessa Lemos Vilela.

\section{REFERÊNCIAS}

[1] APELBLAT, A.; MANZUROLA, E. Solubilities of L-aspartic, DL-aspartic, DL-glutamic, p-hydroxybenzoic, oanistic, p-anistic, and itaconic acids in water from $\mathrm{T}=278 \mathrm{~K}$ to $\mathrm{T}=345 \mathrm{~K}$. The Journal of Chemical Thermodynamics, $\mathrm{v}$. 29, p. 1527-1533, 1997.

[2] GODOI, K. R. R.; BASSO, R. C.; BUSCATO M. H. M.; CARDOSO, L. P.; KIECKBUSCH, T. G.; RIBEIRO, A.P.B.

Dispersed free phytosterols as structuring agentes in lipids systems with reduced saturated fat. Grasas y Aceites, v. 68 p. 1-15, 2017.

[3] de GREYT, W.; KELLENS, M. Deodorization. In: SHAHID, F. Bailey's Industrial Oil and Fat Products. Hoboken (New Jersey), John Wiley \& Sons, Inc, 2005, v. 5, cap. 8, p. 341-383.

[4] HOED, V. V.; DEPAEMELAERE,G.; AYALA, J. V.; SANTIWATTANA, P.; VERHE, R.; DE GREYT, W. Influence of chemical refining on the major and minor componentes of rice bran oil. Journal of American Oil Chemist's Society, v. 83, p. 315-321, 2006. 
[5] ITO, V. M.; MARTINS, P. F.; BATISTELA, C. B.; WOLF-MACIEL, M. R. Tocopherols and phytosterols concentration from soybean oil distillate. In: ENPROMER, 2005, Costa Verde, (Rio de Janeiro), Brasil.

[6] MOREAU, R. A.; WHITAKER, B. D.; HICKS, K. B. Phytosterols, phytostanols, and their conjugates in foods: structural diversity, quantitative analysis, and health-promoting uses. Progress in Lipid Research, v. 43, p. 457-500, 2002.

[7] PANPIPAT, W.; DONG, M.; XU, X.; GUO, Z. Thermal properties and nanodispersion behavior of synthesized $\beta$ sitosterol acyl esters: A structure-activity relationship study. Journal of Colloid and Interface Science, v.407, p. 177186, 2013.

[8] VAIKOUSI, H.; LAZARIDOU, A.; BILIADERIS, C. G.; ZAWISTOWSKI; J. Phase transitions, solubility, and crystallization kinetics of phytosterols and phytosterol-oil blends. Journal of Agricultural and Food Chemistry, v.55, p. 1790-1796, 2007.

[9] WEI, D.; WANG, L.; LIU, C.; WANG, B. $\beta$-Sitosterol solubility in selected organic solvents. Journal of Chemical \& Engineering Data, v. 55, p. 2917-2019, 2010.

[10] YAN, F.; YANG, H.; LI, J.; WANG, H. Optimization of phytosterols rcecovery from soybean oil deodorizer distillate. Journal of American Oil Chemists Society, v. 89, p. 1363-1370, 2012. 


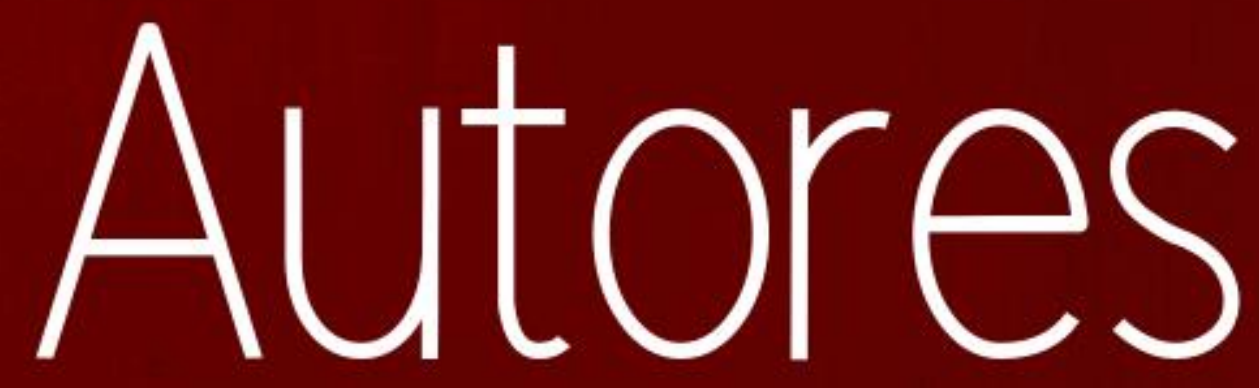




\section{ABIGAIL JAYNNARA GOMES DA SILVA ALMEIDA}

Graduando em Zootecnia pela Universidade Federal Rural de Pernambuco.

\section{ADRIANA FLACH}

Possui graduação em Química Licenciatura Plena pela Universidade Federal de Santa Maria (1998), mestrado em Química pela Universidade Federal de Santa Maria (2000) e doutorado em Química pela Universidade Estadual de Campinas (2005). Atualmente é professor associado 4 da Universidade Federal de Roraima. Tem experiência na área de Química, com ênfase em Química Orgânica, atuando principalmente nos seguintes temas: composição química e atividade biológica de produtos naturais e ecologia química.

\section{AMANDA RAQUEL GUERREIRO MAIA}

Graduada em Tecnologia em Alimentos pelo Instituto Federal de Educação, Ciência e Tecnologia da Paraíba - IFPB Campus - Sousa.

\section{ANA CLARA DE ALVARENGA MORAIS}

Nutricionista. Mestre em Tecnologia Agroalimentar pela Universidade Federal da Paraíba. Docente do curso de Nutrição da Universidade Vale do Rio Doce - Governador Valadares-MG.

\section{ANDERSON FERREIRA VILELA}

Técnico em Química (CEFET-MG). Técnico em Especial em Cervejaria (Câmara da Indústria e Comércio da Alta Baviera -Alemanha /SENAI-RJ). Farmacêutico (UFMG). Mestre em Ciência de Alimentos. Doutor em Engenharia de Processos (UFCG). Professor do Curso de Agroindústria da UFPB. Experiência com ciência e tecnologia de bebidas, em especial cachaças e cervejas artesanais.

\section{ARIANNE DANTAS VIANA}

Profa. do Campus III da UFPB. Doutora em Ciência de Alimentos (UFLA). Mestre em Engenharia de Alimentos (UESB). Graduada em Engenharia de Alimentos (UESB).

\section{BEATRIZ OLIVERIA DE SOUZA}

Graduada em Tecnologia em Agroecologia.

\section{DANIELA CAVALCANTE DOS SANTOS CAMPOS}

Possui graduação em Tecnologia Agroindustrial pela Universidade do Estado do Pará (2005). Mestre em Ciência e Tecnologia de Alimentos pela Universidade Federal do Pará (2008). Doutora em Biodiversidade e Biotecnologia pela Universidade Federal de Roraima (2017). Atualmente é Professora EBTT classe D403, da Escola Agrotécnica da Universidade Federal de Roraima, Campus Murupu. Responsável pela Disciplina de Tecnologia de Produtos Agropecuários (Curso Técnico em Agropecuária e Tecnologia em Agroecologia) e Bioquímica (Tecnologia em Agroecologia). Responsável técnico pelo Laboratório de Tecnologia de Produtos Agropecuários desde 2010. Foi Coordenadora de Assistência Estudantil (2011 - 2012) e Coordenadora Pró -Tempore do Curso de Graduação de Tecnologia em Agroecologia (2018-2018 e 2020-2020). Coordenadora Geral de Ensino de Ensino da EAGRO/UFRR (2016 -2021). Atua em Projetos de Pesquisa na área de produtos lácteos suplementados com microrganismos probióticos, frutas nativas da Amazônia e tuberosas amiláceas. 


\section{DEBORAH HELENA MARKOWICZ BASTOS}

Graduada em Engenharia Agronômica pela Universidade de São Paulo (1982), mestrado em Ciências dos Alimentos pela Universidade de São Paulo (1989) e doutorado em Engenharia de Alimentos pela Universidade Estadual de Campinas (1996). Professor Associado da Universidade de São Paulo, aposentada em 2016. Foi docente colaborador do Mestrado Erasmus MundusFIPDes. É editor associado do periódico Molecules desde 2007. Foi editor associado da Nutrire. Atua como revisor de vários periódicos da área e como Assessor Científico de várias Instituições de fomento à pesquisa (FAPESP, FAPEMAT, CNPq).

\section{ELESSANDRA DA ROSA ZAVAREZE}

Graduação em Engenharia de Alimentos pela Universidade Federal do Rio Grande (FURG), Mestrado em Ciência e Tecnologia Agroindustrial pela Universidade Federal de Pelotas (UFPel) e Doutorado em Engenharia e Ciência de Alimentos pela Universidade Federal do Rio Grande (FURG). Atualmente é Professora Associada e Coordenadora do Programa de Pós-Graduação em Ciência e Tecnologia de Alimentos da UFPel. Membro do Comitê de Assessoramento da Ciências Agrárias da FAPERGS. Presente na Lista do Ranking dos $2 \%$ dos pesquisadores mais citados em 2019, publicado pela Plos Biology.

\section{ELOÍSA HELENA MEDEIROS CUNHA. E-MAIL:}

Professora do Curso de Nutrição da Universidade Vale do Rio Doce, Governador Valadares-MG. Nutricionista (UNIVALE). Especialista em Processamento e Controle de Qualidade em Carne, Leite e Ovos (UFLA). Especialista em Nutrição Humana e Saúde (UFLA). Mestre em Nutrição e Saúde (UFMG). Doutora em Bioquímica e Biologia Molecular (UFJF). Experiência técnica-científica no Centers for Disease Control and Preventions (CDC) (Multiplex-Luminex) e na Emory University em Atlanta/EUA (Metabolômica).

\section{FABIANA MARIA DA SILVA}

Zootecnista com Mestrado e Doutorado em Produção Animal (Produção de Ruminantes). Experiência na área de Bovinocultura Leiteira e Tecnologia de Leite e Derivados. Atualmente é professora Associada I da UAST/UFRPE

\section{FELIPE MOREIRA DA SILVA}

Técnico em Agroindústria pelo Colégio Agrícola Vidal de Negreiros - Universidade Federal da Paraíba, aluno curso de bacharelado em Agroindústria - UFPB campus III.

\section{FERNANDO FELIPE DA SILVA PEREIRA}

Mestrando na Universidade Federal do Ceará, Zootecnista pela Universidade Federal Rural de Pernambuco.

\section{GENI RODRIGUES SAMPAIO}

Possui graduação em Ciências Biológicas, especialização em vigilância sanitária de alimentos (FSP USP), mestrado (2004) e doutorado (2009) em Nutrição Humana Aplicada pela Universidade de São Paulo. Desde 2008 é especialista de laboratório e a responsável técnica pelo Laboratório de Componentes Alimentares e Saúde da Faculdade de Saúde Pública da Universidade de São Paulo.

\section{GLEYCE SWELLEN DE AZEVEDO MOURA}

Técnica em Agroindústria pelo Colégio Agrícola Vidal de Negreiros. Bacharel em Agroindústria pela Universidade Federal da Paraíba. 


\section{GRAZIELLY MIRELLY SARMENTO ALVES DA NÓBREGA}

Graduada em Tecnologia em Alimentos pelo Instituto Federal de Educação, Ciência e Tecnologia da Paraíba - IFPB Campus - Sousa. Apresenta enfoque na área de Microbiologia de alimentos e Produção Industrial de Queijo.

\section{JARINE AMARAL DO EVANGELHO}

Nutricionista graduada pela Universidade Federal de Pelotas (UFPel). Doutora e Mestre em Ciência e Tecnologia de Alimentos pelo Programa de Pós-Graduação em Ciência e Tecnologia de Alimentos (PPGCTA - UFPel). Especialista em Ciências e Tecnologias na Educação (2016) pelo Instituto Federal Sul-Rio-Grandense (IFSUL) e Especialista em Ciência de Alimentos - com ênfase em Tecnologia de Frutas e Hortaliças - pela Universidade Federal de Pelotas (2016). Especialista em Nutrição Esportiva (UNINTER- 2017).

\section{JÉSSICA CRISTINA SILVA RESENDE}

Graduada no Bacharelado em Ciência e Tecnologia e no Bacharelado em Engenharia Química da Universidade Federal de Alfenas (Unifal-MG)

\section{JOSE DE JESUS BERRIOS}

Cientista Pesquisador de Alimentos no USDA-ARS-WRRC. Ampla experiência nas áreas de pesquisa aplicada e básica de Alimentos e Agricultura. Líder do programa de extrusão de alimentos no USDA-ARS-Western Regional Research Center, desenvolvendo processos e formulações para aumentar a utilização de leguminosas por meio da fabricação de novos alimentos extrusados de valor agregado e produtos alimentícios com propriedades nutricionais e funcionais otimizadas e atributos sensoriais desejáveis; massas e bebidas; alta proteína e fibra dietética, produtos sem glúten com baixo IG e atividade potencial de redução do colesterol.

\section{JULIANA LOPES SILVA}

Nutricionista formado pela Universidade Vale do Rio Doce - Governador Valadares-MG.

\section{KAROLINA SOARES COSTA}

Graduada no Bacharelado em Ciência e Tecnologia e no Bacharelado em Engenharia Química da Universidade Federal de Alfenas (Unifal-MG)

\section{KEYLA LAURA DE LIRA DOS SANTOS}

Possui graduação em Zootecnia pela Universidade Federal Rural de Pernambuco (2006), mestrado em Zootecnia pela Universidade Federal Rural de Pernambuco (2008) e doutorado em Zootecnia pela Universidade Federal Rural de Pernambuco (2012) com ênfase em Nutrição e Alimentação Animal. Atualmente é professora adjunta da Universidade Federal Rural de Pernambuco- Unidade Acadêmica de Serra Talhada. Tem experiência na área de Zootecnia, atuando principalmente nos seguintes temas: avaliação de alimentos, nutrição e produção de ruminantes.

\section{LUCILE TIEMI ABE-MATSUMOTO}

Possui graduação em Farmácia-Bioquímica pela Universidade Estadual Paulista Júlio de Mesquita Filho- UNESP (2001), mestrado em Ciências dos Alimentos pela Universidade de São Paulo - USP (2007) e Doutorado em Ciências pela Universidade de São Paulo - USP (2016). Atualmente é Pesquisadora Científica do Núcleo de Química, Física e Sensorial do Centro de Alimentos do Instituto Adolfo Lutz. 


\section{MAILZA GONÇALVES DE SOUZA}

Mestranda em ciência animal pela Universidade Estadual Paulista- Faculdade de Ciências Agrárias e Veterinárias. Zootecnista formada pela Universidade Federal Rural de Pernambuco - Unidade Acadêmica de Serra Talhada. Técnica em Agropecuária pelo Instituto Federal de Educação, Ciência e Tecnologia do Sertão Pernambucano - Campus Floresta. Durante a graduação realizou pesquisas sobre qualidade bromatológica e microbiológica de alimentos, e cadeia produtiva do leite (PIBIC/CNPq). Participou de trabalhos de extensão na área de bovinocultura leiteira

\section{MARIA JOSÉ DE FIGUEIREDO}

Engenharia de Alimentos pela Universidade Federal da Paraíba (1997), mestrado em Ciência e Tecnologia de Alimentos pela Universidade Federal da Paraíba (2000) e doutorado em Engenharia de Processos pela Universidade Federal de Campina Grande (2020). Atualmente é professor adjunto IV da Universidade Federal da Paraíba - campus III.

\section{MARIANA DIAS ANTUNES}

Graduada em Bacharelado em Química de Alimentos pela Universidade Federal de Pelotas (2014). Mestre em Ciência e Tecnologia de Alimentos pela Universidade Federal de Pelotas (2016). Doutora em Ciência e Tecnologia de Alimentos pela Universidade Federal de Pelotas (2018). Atualmente trabalha como Consultora em Rotulagem de Alimentos e Bebidas.

\section{MARLUS PINHEIRO ROLEMBERG}

Graduado em Engenharia Química pela Universidade Federal do Rio Grande do Norte (UFRN) e mestre e doutor em Engenharia Química pela Universidade Estadual de Campinas (Unicamp)

\section{MATEUS GONÇALVES SILVA}

Graduado em Agroecologia pelo Instituto Federal da Paraíba, Mestrando em Sistemas agroindustriais pela Universidade Federal de Campina Grande PPGSA-UFCG. Atua com pesquisas relacionadas à cadeia de produção animal.

\section{MATHEUS BELLICE GREGÓRIO}

Nutricionista formado pela Universidade Vale do Rio Doce - Governador Valadares-MG.

\section{MIKASSIA ROSA FAUSTINO}

Técnica em Agroindústria pelo Colégio Agrícola Vidal de Negreiros - Universidade Federal da Paraíba, e aluna do curso de bacharelado em Gestão Pública - UFPB campus I.

\section{NAIARA MENEZES BEZERRA}

Graduada em Tecnologia em Alimentos pelo Instituto Federal de Educação, Ciência e Tecnologia da Paraíba - IFPB Campus - Sousa. Apresenta enfoque na área de Análise Físico-Química de alimentos e Produção Industrial de Queijo e derivados lácteos.

\section{NATHAN LEVIEN VANIER}

Engenheiro Agrônomo graduado na Faculdade de Agronomia "Eliseu Maciel" (FAEM) da Universidade Federal de Pelotas. Mestre e Doutor em Ciência e Tecnologia de Alimentos pelo Programa de Pós-Graduação em Ciência e Tecnologia de Alimentos do DCTA-FAEM-UFPel. Professor Adjunto do Departamento de Ciência e Tecnologia Agroindustrial da FAEM-UFPel e líder da Rede Latino-Americana de Qualidade de Arroz. Diretor Geral da Labgrãos Magazine (ISSN 25947141) desde sua criação, em 2017. 


\section{NELSON GOMES DE OLIVEIRA JÚNIOR}

Nutricionista formado pela Universidade Vale do Rio Doce - Governador Valadares-MG.

\section{RAFAEL LOPES SOARES}

Zootecnista pela Universidade Federal Rural de Pernambuco (UFRPE), Unidade Acadêmica de Serra Talhada (UAST), mestre em Zootecnia pela Universidade Federal da Paraíba (UFPB). Atualmente faz parte do Programa de Doutorado Integrado em Zootecnia, na Universidade Federal da Paraíba (UFPB). Tem experiência na área de Zootecnia, na linha de pesquisa de Produção de Ruminantes. Com ênfase em conservação de forragens e nutrição de ruminantes.

\section{RODRIGO CORRÊA BASSO}

Rodrigo Corrêa Basso é graduado em Engenharia de Alimentos pela Universidade Estadual Paulista "Júlio de Mesquita Filho" e mestre e doutor em Engenharia de Alimentos pela Universidade Estadual de Campinas (Unicamp)

\section{ROGÉRIO LOPES XAVIER}

Graduação em Agroecologia, Técnico em Agropecuária. Experiência na área das ciências Agrárias, com ênfase em Agroecologia e Zootecnia, atuando principalmente nos seguintes temas: manejos de pastagem, manejo reprodutivo de ovinos e caprinos, e cultivo de cultura anuas e hortifrutigranjeiro, experiência em mecanização agrícola em consonância na operação e manutenção de tratores agrícolas, construções rurais, atualmente extensionista rural na Agricultura familiar.

\section{SUELY CRISTINA PEREIRA DE LIMA OLIVEIRA}

Possui graduação em Medicina Veterinária pela Universidade Federal da Paraíba(2001), mestrado em Medicina Veterinária de Pequenos Ruminantes pela Universidade Federal de Campina Grande(2005) e doutorado em Medicina Veterinária pela Universidade Federal de Campina Grande(2016). Atualmente é Professor de ensino técnico e tecnológico do Instituto Federal de Educação, Ciência e Tecnologia da Paraíba - IFPB.

\section{THAIS SILVEIRA PEREIRA}

Atua no Laboratório de Microbiologia da Universidade Vale do Rio Doce, Governador ValadaresMG. Graduada em Ciência Biológicas (UNIVALE). Especialista em Análises Clínicas e Gestão de Laboratório (UNIVALE). Especialista em Perícia e Auditoria Ambiental (UNVALE).

\section{VANESSA VILELA LEMOS}

Graduada no Bacharelado em Ciência e Tecnologia e no Bacharelado em Engenharia Química da Universidade Federal de Alfenas (Unifal-MG)

\section{VÂNIA ZANELLA PINTO}

Possui graduação em Engenharia de Alimentos pela Universidade de Passo Fundo (2009). Mestrado em Ciência e Tecnologia Agroindustrial pela Universidade Federal de Pelotas (2011) e Doutorado em Ciência e Tecnologia de Alimentos pela Universidade Federal de Pelotas. Atualmente é professora na Universidade Federal da Fronteira Sul (UFFS), campus de Laranjeiras do Sul, no curso de Engenharia de Alimentos e membro permanente do Programa de PósGraduação em Ciência e Tecnologia de Alimentos - UFFS (PPGCTAL- UFFS). 


\section{VIRGÍNIA MEDEIROS DE SIQUEIRA}

Graduada em Biomedicina, com Especialização em Micologia e Mestre em Biologia de Fungos pela Universidade Federal de Pernambuco. Com experiência na área de Microbiologia, com ênfase em Micologia (com nova espécie descrita Corynespora subcylindrica). É Doutora em Engenharia Química e Biológica pela Universidade do Minho, Portugal, com projeto na área de biofilmes fúngicos e seu estudo através de Fluorescent in situ hybridization (FISH) e microscopia de fluorescência. Com Pós Doutorado pela Universidade Estadual de Campinas - UNICAMP, com projeto sobre biofilmes em sistemas de membrana de osmose, com a aplicação de técnicas cultivo independentes como FISH e caracterização de comunidades microbianas pela construção de bibliotecas de DNA e RNAr 16S. Atual Professora Adjunta da Universidade federal Rural de Pernambuco, Unidade Acadêmica de Serra talhada, na área de Microbiologia Geral e Microbiologia de Alimentos.

\section{VIVIANE ANTUNES PIMENTEL}

Professora da Universidade Federal de Roraima. Possui graduação em Zootecnia pela Universidade Federal Rural do Rio de Janeiro (2004) e Licenciatura em Ciências Biológicas pela Universidade Salgado de Oliveira, mestrado em Ciência Animal pela Universidade Federal Rural do Rio de Janeiro (2005) e doutorado em Ciência Animal pela Universidade Estadual do Norte Fluminense (2010). Tem experiência na área de Zootecnia, com ênfase em Nutrição e Alimentação Animal, atuando principalmente nos seguintes temas: ovinocultura, caprinocultura, bovinocultura, forragicultura e pastagens.

\section{YASMIN KELLEN DE OLIVEIRA MACHADO}

Nutricionista formado pela Universidade Vale do Rio Doce - Governador Valadares-MG. 
